\title{
Myth and Reality in Irregular Migration from Myanmar
}

\author{
By
}

\section{KO KO SI THU}

\author{
A thesis \\ submitted to the Victoria University of Wellington \\ in fulfilment of the requirements of the degree of \\ Masters in Development Studies
}

School of Geography, Environment and Earth Sciences

Victoria University of Wellington 



\section{ACKNOWLEDGEMENTS}

I firstly thank my mom and dad for their moral support and prayers with everything I do.

I would like to express my gratitude to my research supervisor Dr. Alan Gamlen. His guidance and encouragement has been vital for me in accomplishing this thesis.

Heartfelt thanks go to my interviewees for sharing their experience. This thesis would not have been possible without their willingness to participate and hospitality during my fieldwork.

I am grateful to New Zealand Agency for International Development (NZAID) and its team for their support for me in pursuing Masters of Development Studies (MDevStud) at Victoria University of Wellington.

My deepest thanks also go to U Thant Zin, U Saing Mon and Ko Naw Mine for their assistance. Their helps in choosing the study area and suitable participants have been an important part in successfully completing my fieldwork.

I am also indebted to my mentors $U$ Bo Bo Lwin, Ross and Helen Wilson, Karen Falconer and Mary Busch. Their kind support and guidance have been crucial for me to be able to pursue this master's degree.

Last, but not least, I thank my classmates for sharing their valuable ideas through classroom discussions and chatting. Learning together with them was where I realized learning comes not only from teachers but also from colleagues. 


\section{ABSTRACT}

Migration studies is an interdisciplinary study within a broader field of development studies due to its association with debates about development and underdevelopment. Irregular migration is one of the most significant topics in migration studies and its complex nature has attracted many scholars from around the world. Most literature on irregular migration has focused on its illegality and the situation of irregular migrants in the destination country and therefore, much of the previous literature on irregular migration only presents the process as a dangerous and abusive phenomenon for irregular migrants, and depicts brokers and agents as evil and exploitative. Public perception and policy discussions are dominated by myths, rather than facts, about debts and danger. These established myths often overshadow the reality about the impacts of irregular migration as experienced by actual migrants and their local communities. These confused interpretations of irregular migration highlight a need for further research.

This thesis examines a case of cross-border irregular migration from Myanmar to Thailand in order to explore the impacts of irregular migration in a wider field. Its main purpose is to investigate the processes and impacts of irregular migration on families left behind in sending areas. This is achieved by employing a qualitative case study approach to gain deeper understanding of the topic in the local context, using two data collection methods: participant observation and semi-structured interviews. The study hypothesizes that irregular migration in the Myanmar context conforms less to the "evil" image, than to the patterns of conventional labour migration described by the "New Economics of Labour Migration" theory. The main research questions posed to achieve these aims were: What are the processes of irregular migration? What are its impacts on families left behind? How are these impacts different from the impacts resulting from legal migration?

The study draws two main conclusions. First, human smuggling operations in this study's context are based on the personal contacts, and therefore irregular migration is often accomplished with the help of friends, relatives or siblings of the migrants 
themselves and not by hostile, exploitative smugglers. Secondly, departing from the traditional notion that irregular migration is harmful, the findings from this study suggest that the social and economic impacts resulting from irregular migration are surprisingly similar to the impacts of conventional international migration in many respects. 


\section{TABLE OF CONTENTS}

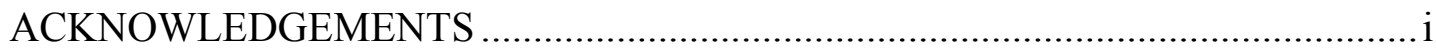

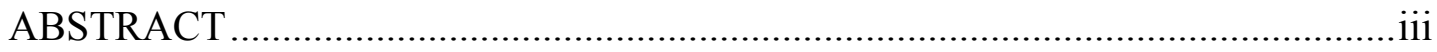

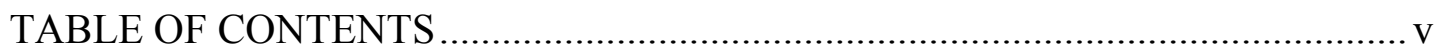

List of tables and figures ........................................................................................ vii

List of abbreviations....................................................................................... vii

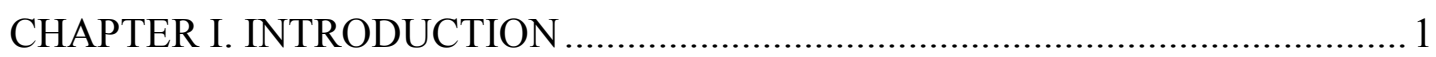

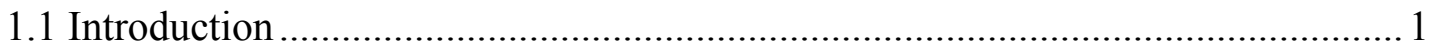

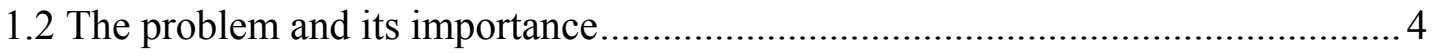

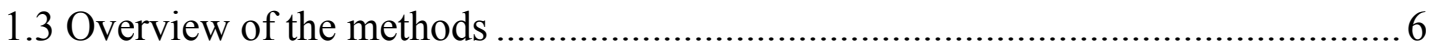

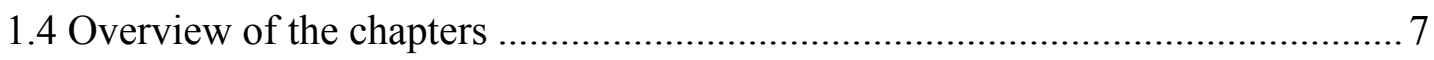

CHAPTER II: LITERATURE REVIEW .......................................................... 9

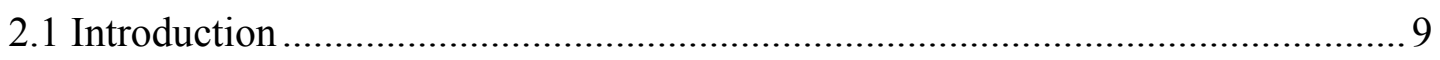

2.2 Irregular migration in Myanmar-Thailand cross border migration context .......... 9

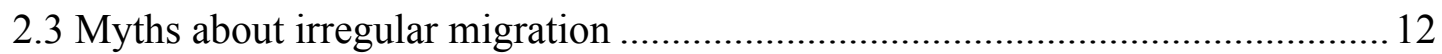

2.4 Studying the impacts of migration on families left behind ................................ 19

2.5 Applying New Economics of Labour Migration to irregular migration process 26

2.6 Developing research questions and a hypothesis for this study .........................22

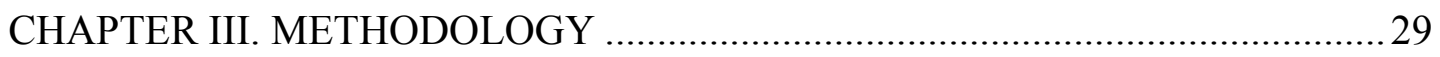

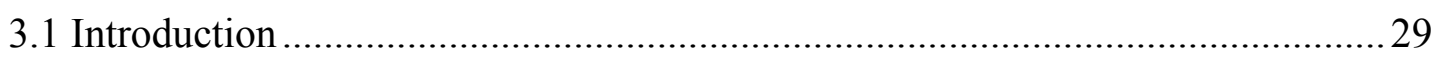

3.2 Positionality of the researcher and the issue of power......................................2 29

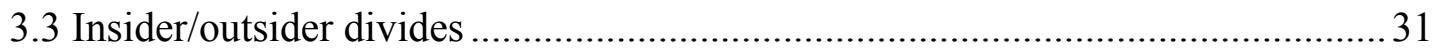

3.4 Qualitative research and case study approach................................................... 33

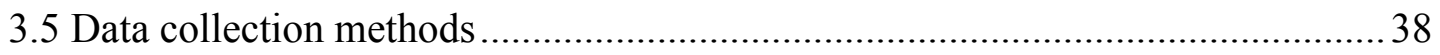

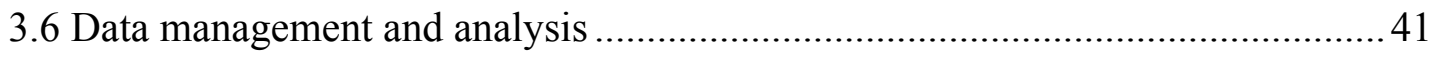

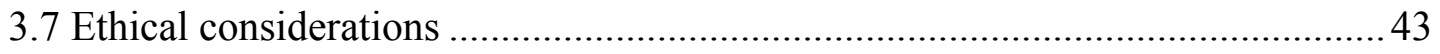

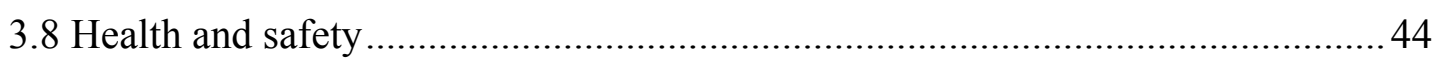

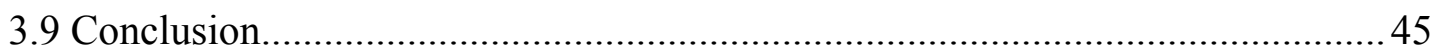

CHAPTER IV: PROCESSES OF IRREGULAR MIGRATION IN THE LOCAL

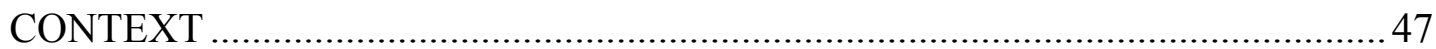

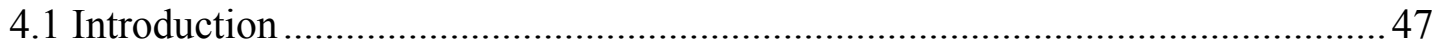

4.2 Processes of human smuggling in the local context...........................................4 47

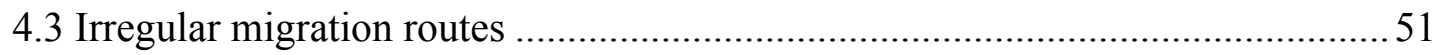

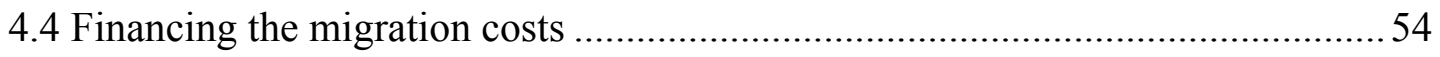

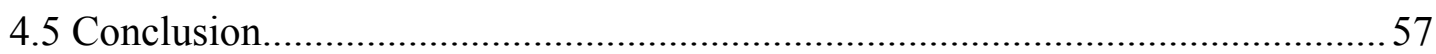


CHAPTER V: ECONOMIC IMPACTS OF IRREGULAR MIGRATION ON

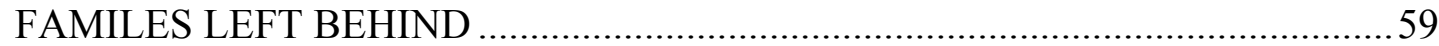

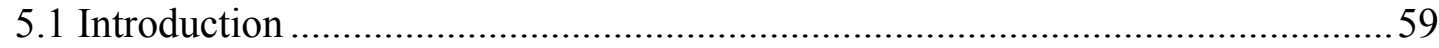

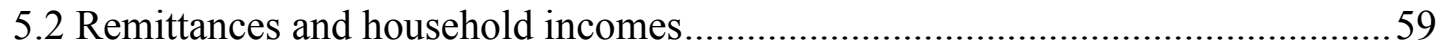

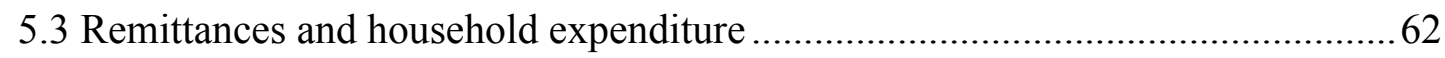

5.4 Remittances and general economic impacts..................................................... 71

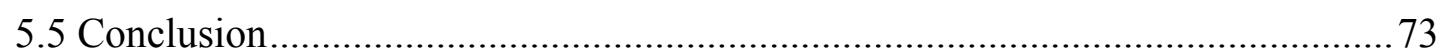

CHAPTER VI: SOCIAL IMPACTS OF IRREGULAR MIGRATION ON

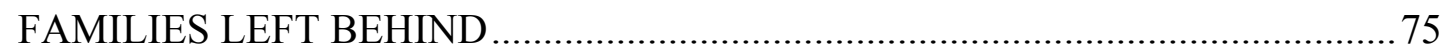

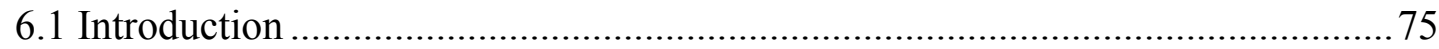

6.2 Adjustment within families in the absence of one or more family members....... 75

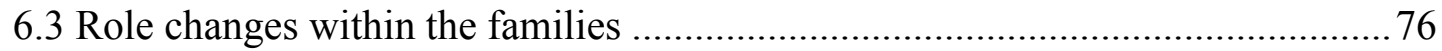

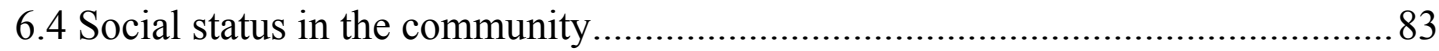

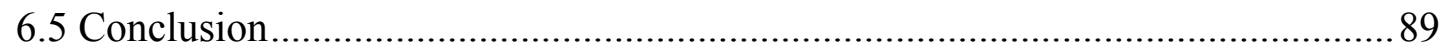

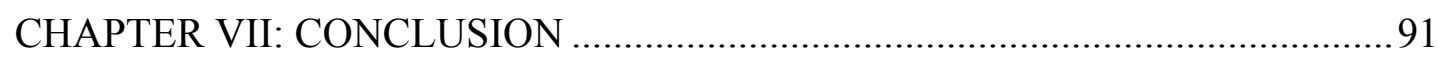

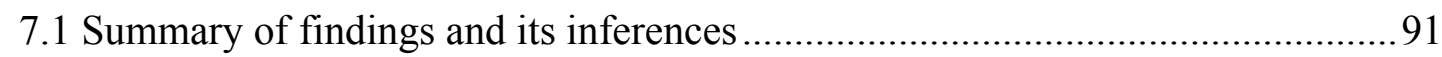

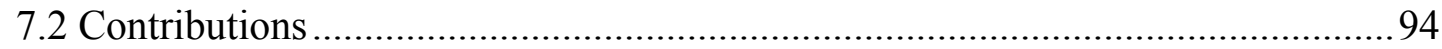

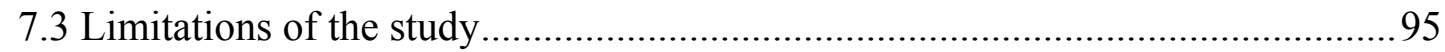

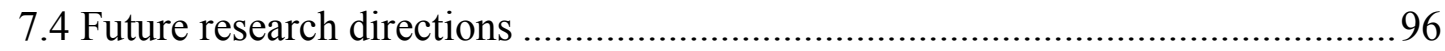

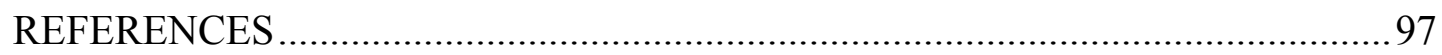

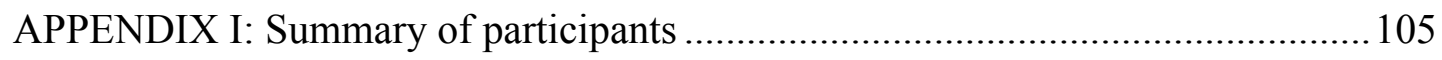

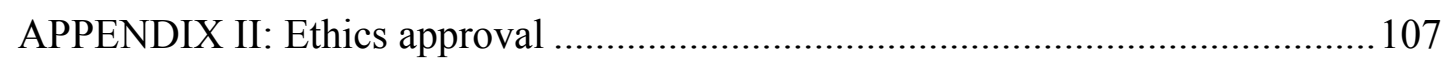

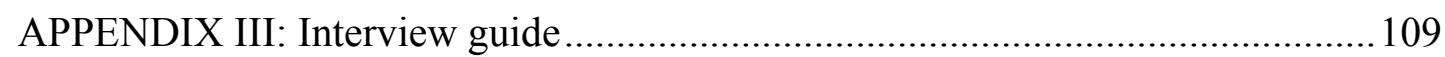

APPENDIX IV: Questionnaires (Burmese) …..................................................... 111

APPENDIX V: Information for participants (Burmese) ........................................ 113

APPENDIX VI: Participant information sheet ................................................... 115

APPENDIX VII: Information letter to village (Burmese) ..................................... 117

APPENDIX VIII: Location map of Kayah State .................................................... 119

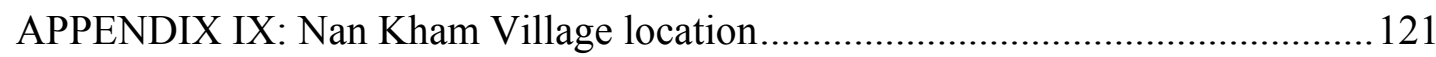




\section{List of tables and figures}

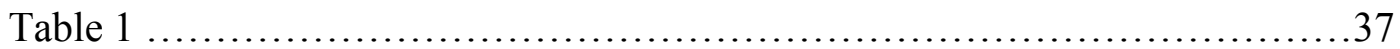

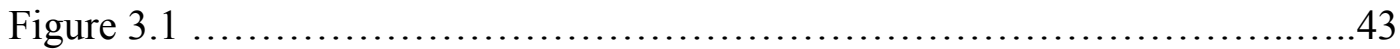

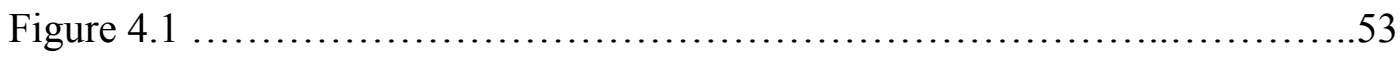

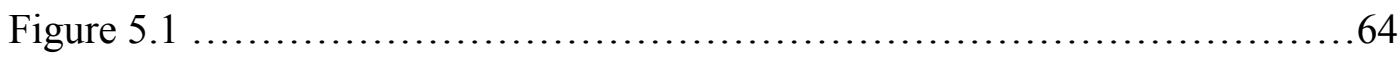

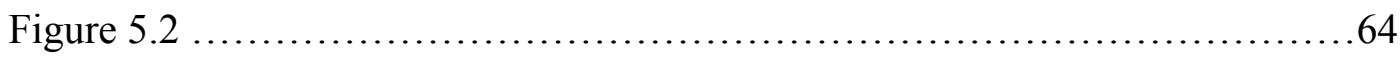

List of abbreviations

$\begin{array}{ll}\text { EPC } & \text { - Electric Power Corporation } \\ \text { INGO } & \text { - International Non-government Organization } \\ \text { IOM } & \text { - International Organization for Migration } \\ \text { KMF } & \text { - Kalyana Mitta Foundation } \\ \text { KNPLF } & \text { - Karenni Nationalities People Liberation Front } \\ \text { LNGO } & \text { - Local Non-government Organization } \\ \text { NELM } & \text { - New Economics of Labour Migration } \\ \text { UNHCR } & \text { - United Nations High Commissioner for Refugees } \\ \text { UNODC } & - \text { United Nations Office on Drugs and Crimes }\end{array}$




\section{CHAPTER I. INTRODUCTION}

\subsection{Introduction}

Observe the following quotes.

"54 Burmese migrants suffocate in packed lorry” - Guardian Online, April 2008

"People acknowledge me as a good example of working abroad. And they came and ask me to take their children on my return to Thailand." - (Personal communication, April 22, 2014)

The first quote was is among a number of media news items that have been related to the process of human smuggling from Myanmar to Thailand. Human smuggling, sometimes mistakenly equated with human trafficking, has been one of the most serious issues concerning authorities for both Myanmar and Thailand. Likewise, the stories reported in the media about human smuggling have been always associated with criminal networks, prostitution, slavery and exploitation. The result is an extremely unpleasant image of human smuggling. For the receiving states, this irregular flow of migrants is seen as a threat to national security. For the sending countries, it is understood as a problem to be taken care of by enforcing tighter border control. Hall (2009) argues that migrants in Thailand, particularly irregular migrants from Myanmar, are considered as "the most exploited, excluded and abused sector in Thai society" (p.5). In the light of this, there are many recommendations to regularize the existing Myanmar migrants and to deter any future flow of irregular migrants from Myanmar. The "evil face" of human smuggling has become one of the most discussed issues in both policy and public debate in this region.

The second quote tells an entirely different story about irregular migration. It comes from my conversation with a so-called local smuggler ${ }^{1}$. He started smuggling

\footnotetext{
${ }^{1} \mathrm{He}$ is described as an ex-transporter in later discussions. See the detailed explanation in Sampling and Recruitment section of Chapter III.

${ }^{2}$ Village name and all interview participant names are pseudonyms

${ }^{3}$ Refer to the map on Appendix VIII.
} 
migrants across the border to Thailand because a lot of people asked him to do so. He said "I was just helping them to make much more money than staying in the village" (personal communication, April 22, 2014). It was just a way of making a living and he never thought of his act as 'illegal'. As the quote illustrates, other villagers relied on him for sending their children to Thailand. He became the first to build a new-concrete building using the remittance monies and because of this, people were inspired by him and started asking about how to migrate. He smuggled migrants across the Kayah state-Thailand border for some years and then retired and started investing in small businesses with his savings from working in Thailand. Thus, he became one of the wealthiest men in the village. In the words of one fellow villager, he had become the 'successful face of the village'.

Clearly, the perspectives of people (or stakeholders) who actually participate in irregular migration are somewhat different from those portrayed to the wider public audience. Exploring how local people think of irregular migration was one of the objectives of my study in Nan Kham ${ }^{2}$ village. Being a local researcher studying my own community, I had the privilege to immerse myself among my research participants and to discover their opinions on irregular migration and the figure of the human smuggler. Two return migrants, from among my participants, said that they relied on the local smuggler for going to Thailand although they were not sure about the trip. They said, "I would not have gone unless it was with him" and "It was because of him that I could go to work in Thailand and save money" (Daw Hla, personal communication, June 10, 2014). Those migrants who had participated in this smuggling process, had never considered it risky or dangerous. Based on their responses, I came to understand that the relationship between the local smuggler and the migrant was not based on deception and exploitation, but on trust and familiarity. The reputation of the local smuggler in the village was not that of a dangerous criminal, but rather as a person who provided an opportunity for other villagers to advance their living standard.

This surprisingly optimistic view was also evident in my participants' views about the impacts of irregular migration. The impacts they mentioned were the

\footnotetext{
${ }^{2}$ Village name and all interview participant names are pseudonyms
} 
improvements of the housing and living standards of households in the village. Throughout a series of interviews, no participants mentioned 'human smuggling' or 'illegal migration'. Instead, they just used terms such as 'going to Thailand or Bangkok' or 'going to the border'. In other words, crossing the Kayah State-Thailand border $^{3}$ was not seen as a dangerous or a life-risking activity. For some migrants, they even visited their family who remained at the village, 3-4 times a year using the same route ${ }^{4}$. Their reason for not migrating legally or 'by passport' was because of the complex nature of the legal migration process and the higher cost to migrate legally ${ }^{5}$. It was significant that, for them, irregular migration was the only and the best available way to improve the incomes in households, and thereby, to promote their living standards.

Reconciling these contrasting views on the process and impacts of irregular migration was my ultimate aim in undertaking this thesis. An important notion is that irregular migration is seen as the problem which needs to be solved for its affiliation with exploitation, prostitution and human rights violations. As discussed above, the perspectives of local people in Nan Kham village shed an entirely different light on the process and impacts of irregular migration. A number of myths about irregular migration - which identifies the process as always debt-related, dangerous and life threatening - have become established in public perception and policy discussions. These established myths seem to overshadow the reality about the impacts of irregular migration as experienced by the local community. Thus, the myths and confusion associated with interpreting irregular migration called for a set of questions that need to be answered.

What are the myths about irregular migration?

\footnotetext{
${ }^{3}$ Refer to the map on Appendix VIII.

${ }^{4}$ The irregular migration routes used by my participants are explained in detail in Chapter IV.

${ }^{5}$ Until 2013, Yangon (former capital) was the only place that issued passports for Myanmar citizens. The ideal processing time usually took more than a month and documents needed for the application process (such as birth certificate, tax exemption letter) were the documents that most in the rural population did not have in many cases. Most importantly, the fulfilments needed while applying for a Thai visa was also a barrier for most migrants. Firstly, every migrant worker needed to submit an 'offer of job letter', proof of ownership or cash in hand to apply for a work visa. Again, obtaining these documents was costly and entailed a complicated process.
} 
How do these myths compare with the reality about the process and impacts of irregular migration?

These questions form the foundation of this thesis. On the basis of these questions, the focus of this research project shifted away from human trafficking and more towards the actual experiences of people. It should be acknowledged that the research focus is limited to the case of human smuggling as a voluntary activity, and its impacts on families left behind.

\subsection{The problem and its importance}

This thesis examines a case of cross-border irregular migration from Myanmar to Thailand in order to explore the impacts of irregular migration in a wider field. Its main purpose is to investigate the process and impacts of irregular migration on families left behind in sending areas. This is achieved through a case study about families left behind in a rural village in Myanmar. The case study explored the processes and impacts of irregular migration as understood by the local community through personal interviews and participant observation. My hypothesis is that irregular migration in the Myanmar context conforms less to the "evil" image, than to the patterns of labour migration, described by the "New Economics of Labour Migration" theory. The main research questions posed to further understand this issue were: What are the processes of irregular migration? What are its impacts on families left behind? How are these processes and impacts different from those of legal migration?

The significance of this study impacts on both the practical and academic spheres. In practical terms, this study is a substantial contribution to lessen the scarcity of formal research in Myanmar. Due to the difficulty in conducting research within the country itself over many decades, research projects relating to irregular migration from Myanmar to Thailand have therefore been solely based on the socio-economic conditions and living situations of Myanmar migrant workers in Thailand. This study is an attempt to fill this gap by investigating the process and impacts of irregular 
migration through exploring local people's perceptions about the matter, providing a perspective from inside the country.

In addition to remedying the data scarcity, this study intends to address one of the most important issues for growing countries like Myanmar. Irregular cross-border migration from Myanmar to Thailand has unfolded over many decades. The remittances sent back by migrant workers are significant for the rural population in Myanmar which is one of the most impoverished countries in South Asia. Nevertheless, the implications of irregular migration for the development of sending areas have always been disregarded by both Myanmar and Thailand. Given that the overall economic situation in Myanmar has not changed much after the political reforms of a few years ago, irregular migration from Myanmar to Thailand is likely to continue for some period of time (McGann, 2013). In this case, this study is expected to enhance the understanding about irregular migration in local contexts and its implications for local communities in Myanmar for the future reference of law and policy development relating to migration.

On the academic side, this thesis makes a significant contribution to the literature on irregular migration and the migration industry. Its emphasis on the process of irregular migration and its impacts in reference to theories such as 'New Economics of Labour Migration' (NELM), is a distinct and new approach within migration literature. For instance, there is a group of scholars who find that international migration improves the living standards, relative income and the opportunity to invest in productive activities of migrant households in the area of origin (Stark \& Taylor, 1991; Taylor, 1999; Taylor et al., 1996). Their focus has not been exclusively on the case of irregular migration, but included both irregular and regular migration and their impacts. On the other hand, some other studies have sought out the benefits of irregular migration as providing alternative forms of migration (Set Aung, 2009), and helping overcome capital and market constraints for households in the rural areas (Koser, 2008). However, less attention has been given to the impacts of irregular migration and its implications on remaining families in the sending area and the question of how irregularity changes these well-known impacts. Thus, this study attempts to contribute to the wider literature on migration by focusing on the 
processes and impacts of irregular migration on remaining families through the NELM lens.

\subsection{Overview of the methods}

The primary aim of this thesis is to explore the process and impacts of irregular migration on families left behind in the sending areas. This is achieved by employing a qualitative case study approach to gain deeper understanding of the topic in the local context. It follows the advice of Creswell (2003) that qualitative methods are used in studies which are context specific and that prefer information richness rather than large population or site samples.

For the recruitment of the participants, a two-fold sampling strategy was implemented using maximum variation and snowball sampling procedures. First, the participants for the interviews were recruited through a snowball sampling method in which successive recruits are referred by former ones. By using the snowballsampling procedure, the people who are eligible to participate can be recruited through a referral after each interview (Morgan, 2008). After this process has taken place, a maximum variation procedure was applied to direct the recruitments by identifying possible criteria for the participant recruitment relevant to the context. In this way, a list of criteria ${ }^{6}$ for the upcoming recruitment was developed, which was later useful for recruiting suitable participants to enhance the information richness of the study.

Semi-structured interviews and participant observation were used as data collection methods. Descombe (2007) argues that in-depth interviews are used to collect data in respect of people's opinions, feelings and experiences. As such, 16 records of faceto-face interviews were collected during the fieldwork to explore the participants' opinions and experience on the processes and impacts of irregular migration. These interviews were done alongside the participant observation to gain 'immersion [through participant observation] in the setting permitting the researcher to hear, to see, and to begin to experience reality as the participants do' (Marshall \& Rossman,

\footnotetext{
${ }^{6}$ Please refer to the detail in Chapter III.
} 
2006, p.100). These observational field notes were crucial and captured the context vital to the research questions and aided the participant recruitment process during the data collection process. These data were then analysed using a two-fold coding strategy - open coding and thematic coding.

\subsection{Overview of the chapters}

This thesis is structured in the following way. Chapter II is a review of the literature and has two distinct parts. The first part explores conventional beliefs about irregular migration. This includes defining terms relevant to irregular migration as a foundation of the thesis and justification for choosing human smuggling rather than human trafficking. It also critically discusses the 'myths' surrounding the processes involved and implications on migrant households. The second part of this chapter discusses the impacts of international migration on families left behind in sending areas in reference to the New Economics of Labour Migration theory, arguing that this theory provides a better theoretical grounding than existing myths.

Chapter III outlines the methodology employed for this study. It presents my reflection throughout the research project by explaining my positionality as a researcher and issues of power during the fieldwork. The chapter also discusses the rationale for choosing a qualitative case study as the approach to explore the processes and impacts of irregular migration on families left behind. This is followed by a detailed discussion about sampling and recruitment processes, and data collection methods employed in this study. This chapter concludes with a discussion about data management and the analysis stages of the research.

Chapters IV, V and VI present the results of this study. Chapter IV focuses on the findings about the processes of irregular migration in the local context, highlighting the nature of the smuggling business, and the relationship between local smuggler and his clients. Noticeably, it argues that locals perceive the human smuggling business as indistinguishable to any other kinds of business in the village, and the human smuggling process was based on the prior relationship and trust between a local smuggler and the migrants. It also finds that family members, friends and 
relatives were often affiliates to facilitate the human smuggling by providing financial support, information and contacts.

Chapter $\mathrm{V}$ discusses the economic impacts of irregular migration on migrant households and the multiplier effects in the community. This chapter argues that overall incomes are improved in migrant households, as did the expenditure as a result of irregular migration, consistent with the prior NELM studies. Contrary to the negative image of impacts of irregular migration, this study shows rather more positive economic impacts in terms of providing improvements of assets, housing and standard of living and enhancing the amount of personal contributions in village and religious affairs.

This is followed by Chapter VI which provides a detailed explanation of the social impacts of irregular migration on the families left behind, in particular with reference to the types of members left behind, and to such families' social status change in the community. This chapter shows evident role changes in migrant families in terms of the women's status change in the family and the transfer of childcare duties to remaining family members. Most importantly, it argues that irregular migration provides positive social impacts on the family left behind by promoting family's social status which is acquired through having proper housing and an active financial contribution in religious affairs.

Finally, Chapter VII is the concluding chapter which summarizes findings presented in Chapter IV, V and VI. After discussing the inferences from each of those findings, the chapter concludes with suggestions about further research directions. 


\section{CHAPTER II: LITERATURE REVIEW}

\subsection{Introduction}

The structure of this literature review is organized in the following way. First, it explores the context of irregular cross-border migration from Myanmar to Thailand highlighting that previous studies have mainly focused on the drivers rather than the impacts in the area of origin. Following this is the section that outlines the differences in understanding irregular migration, human smuggling and human trafficking. This section also explores the myths about irregular migration which are most discussed within study about irregular migration. Then, the following section discusses the impacts of irregular migration on families left behind in special reference to New Economics of Labour Migration theory. Finally, this chapter concludes with how the literature informed the development of research questions and hypotheses for this study.

\subsection{Irregular migration in Myanmar-Thailand cross border migration context}

\subsubsection{Irregular migration and the importance of migration networks along the Thai-Myanmar border}

Irregular cross-border migration from Myanmar to Thailand has unfolded over many decades. The remittances sent back by migrant workers play a significant role for the rural population in Myanmar which is one of the most impoverished countries in South Asia. In spite of this, the effects of irregular migration for the economic and social development of sending areas has usually been disregarded by the governments of both Myanmar and Thailand. There is no accurate data on the number of Myanmar migrants in Thailand but it is estimated that two to four million migrants are living in Thailand as of 2012 (Hall, 2012). Therefore, Thailand stands as a major destination country for Myanmar migrants followed by Malaysia, Singapore and Korea. According to Hall (2012) major ethnicities of the migrants in 
Thailand were Tavoy, Karen, Mon, Shan and Bamar ${ }^{7}$. Ages range from 14-40, supplementing Thailand's need of labour in agriculture, fishing and domestic services $^{8}$ (Caouette \& Pack, 2002). Existing studies suggest that the reason for this is because of existing migration networks and the economic incentives attracting Myanmar migrants.

Traditionally, people who live along the border, mostly from ethnic groups such as Mon, Karen and Shan, have unofficially travelled back and forth to Thailand for much of their history. According to Chantavanich \& Vungsiriphisal (2012), it has been of an insignificant circumstance to authorities that people travelling to Thailand cross the border to meet friends and relatives and buy materials. However, a noticeable inflow of Myanmar migrants was seen in the 1980s as a result of Myanmar's political unrest and conflicts between ethnic minorities and the military government (Chantavanich \& Vungsiriphisal, 2012). This political unrest and insecurity resulted in thousands of people fleeing to Thailand for safety reasons. Since then, the Thai government agreed to host political asylum-seekers from Myanmar and, as of September 2013, over 16,000 refugees were registered at refugee camps along the Thai-Myanmar border (United Nations High Commissioner for Refugees [UNHCR], 2014). While existing cultural ties seemed to be a reason for Myanmar migrants to see Thailand as a destination, undeniably these immigrants from Myanmar had established social networks which are vital for assisting entry for upcoming Myanmar migrants. These existing social ties were one of the solid foundations for the establishment of migration networks for Myanmar migrants.

A noticeable wave of Myanmar migrants have arrived in Thailand because of its economic incentives and lack of local labour. First, the most important pull factor for Myanmar migrants has been the substantial income differences between the two countries. McGann (2013) highlighted that GDP per capita in Myanmar (1400 USD) was significantly lower than GDP per capita in Thailand (10,000 USD) in 2012. He argued that this attracted Myanmar migrants as in Myanmar over 30 per cent of the

\footnotetext{
${ }^{7}$ There is no exact data on ethnic composition of Myanmar migrants in Thailand. However, it is publicly known that vast majority of Myanmar migrants come from the rural ethnic regions bordering to Thailand.

${ }^{8}$ These are major categories recognized by Thailand government as of 2001. Other sectors include service industry such as massage and prostitution, seasonal work and market vendor.
} 
population live under the poverty line. According to Hall (2012) Myanmar migrants make up to 5 to 10 per cent of the total workforce in Thailand. He highlights the importance of the migration network for this flow of migrants from Myanmar by stating that:

Networks of informal brokers have been established at village levels across Myanmar, linked to smugglers and/or trafficking networks at all borders, to facilitate this migration to neighbouring countries irregularly. These networks are now extensive and ingrained, particularly on the Thai/Myanmar and Thai/Malaysia borders. (Hall, 2012, p. 4)

These long-existent migrant networks along the borders have been crucial in facilitating the flow of irregular migrants from Myanmar.

\subsubsection{Continuing labour demands and flows of irregular migrants}

In addition to the long existing migration network, Thailand's need for labour in lowskill jobs, and immigration policy changes has also influenced the immigration of Myanmar migrants. Thailand's move towards an export-oriented economy in the 1980s has created a large supply of low-skilled jobs, and this has created changes to their migration policies (McGann, 2013). Between 1992 and 1999, a series of four Cabinet Resolutions were passed allowing foreign migrants to work in various workplaces in Thailand (Caouette \& Pack, 2002). The summary of the four Cabinet Resolutions as stated by Caouette \& Pack (2002):

1) 1992 Cabinet Resolution: the first resolution which allowed employment of displaced persons or illegal migrants from Myanmar living in nine border provinces; 2) 1996 Cabinet Resolution: this resolution allowed the registration of migrant workers from Myanmar, Laos and Cambodia and expanded the provinces in which they could work; 3)1998 Cabinet Resolution: to respond to the Asian Economic crisis in 1997, this resolution sought to employ Thai nationals rather than the migrant workers. This was followed by a subsequent Royal Thai Government Resolution which only allowed migrant workers to work for one year; 4) 1999 Cabinet Resolution: this resolution allowed the employment of migrant workers in places where Thai workers were not available.

These policy developments of the Thai government have been influential especially for illegal migration from Myanmar. It was not until 2003 that the inflow of Myanmar migrants had been officially recognized. In 2003, a Memorandum of 
Understanding (MoU) between Myanmar and Thailand took effect in order to improve the employment procedures and protection of Myanmar migrants and to prevent the flow of irregular migrants (McGann, 2013). According to McGann (2013) this involved two strategies: 1) employing migrants directly through a government program and subsequently adopting a National Verification (NV) program to legalize the migrant workers, and 2) to provide benefits such as social security and accident compensation. Despite the Thailand government's attempt to acknowledge the importance of migrant workers, and to regularize illegal migrants, the issue of irregular migrants from Myanmar still remains as an issue under scrutiny as a direct result of these policy processes.

In sum, the rationale behind irregular migration flow from Myanmar to Thailand and the policies of the Thai government have fostered this flow over the last decade. I have highlighted that geographic proximity to Thailand, and displacement due to Myanmar's military regime, created strong networks of refugees and migrants which became vital for the later flow of Myanmar migrants. Irregular migration across the Thai-Myanmar border has been a longstanding matter and it is also noticeable that the Thai government's policy towards Myanmar migrants has changed over the last few decades. Previous studies about irregular migration from Myanmar to Thailand have largely focused on the drivers of migration rather than the impacts in the area of origin. Arguably, they have failed to consider the social and economic consequences of migration for the migrants' sending areas. Next I review the myths about irregular migration in the migration literature to better explore how these well-known myths influence the perception about the impacts of irregular migration.

\subsection{Myths about irregular migration}

\subsubsection{Differences between Irregular migration, human trafficking and human smuggling}

Irregular migration has been gaining interest in many countries in recent years and is commonly known throughout the world as a transnational crime (Salt, 2000). The International Organization for Migration (IOM) defines irregular migration as crossing an international boundary without any inspection or using forged travel 
documents or overstaying in another country when a visa expires (IOM, 2000). Similarly, Koser (2010) states that irregular migration generally refers to the crossborder flow of people from one country to another without proper authorization. In other literature, irregular migration is also expressed as a 'clandestine', 'undocumented' or 'illegal' migration flow from one country to another (Salt, 2000; Skeldon, 2002). However, there is no universally accepted definition of irregular migration as the complex nature of irregular migration is bound to the social and political systems of place of origin and destination states. Smuggling of migrants and trafficking in persons are the most discussed issues in the literature about irregular migration. Both are seen as an illegal form of migration and a transnational crime (Burke, 2008). It highlights the importance of clarifying the meaning of the terms of human smuggling and how it differs from human trafficking in order to investigate the effects of irregular migration.

The most significant differences between human smuggling and human trafficking can be found in the United Nations' Protocols, namely 'Protocol To Prevent, Suppress and Punish Trafficking in Persons, Especially Women and Children' and the 'Protocol Against The Smuggling of Migrants by Land, Sea and Air'. The former protocol states:

Trafficking in persons shall mean the recruitment, transportation, transfer, harbouring or receipt of persons, by means of the threat or use of force or other forms of coercion, of abduction, of fraud, of deception, of the abuse of power or of a position of vulnerability or of the giving or receiving of payments or benefits to achieve the consent of a person having control over another person, for the purpose of exploitation (UN, 2000a, p.2)

Therefore, the definition of human trafficking generally focuses on the evil deeds of traffickers which actually further their ultimate purpose of 'exploitation'. In other words, the trafficked persons are merely victims in the process, and their consent is either not collected or it is obtained by coercion or deception. Furthermore, human trafficking often involves labour exploitation and human rights abuses in the destination country (Salt, 2000). In human trafficking, people are transported against their will, and most end up in situations of forced sex and labour (Burke, 2008).

On the contrary, Article 3 of the UN's Protocol Against The Smuggling of Migrants by Land, Sea and Air describes that: 
Smuggling of migrants shall mean the procurement, in order to obtain, directly or indirectly, a financial or other material benefit, of the illegal entry of a person into a State Party of which the person is not a national or a permanent resident (UN, 2000b, p.2)

Arguably, this Article describes human smuggling as a service between the smugglers and migrants for mutual benefits. For this reason, smugglers can be understood as people who facilitate illegal channels and organize transportation for others to enter another country's territory. In contrast to human trafficking, migrants participating in human smuggling activities are volunteering to be part of the process (Davidson, 2003). In terms of the nature of the service, Davidson (2003) states that human smuggling is more a one-off service, while trafficking may involve long-term control after the migrant arrives at his/her destination. According to these protocols, these differences make human smuggling quite different from human trafficking.

In addition, Burke (2008) argues that human smuggling and human trafficking are different in terms of their organizational structures. She states that human smuggling operates as a small-scale form of business which is run by locals and relatives, while human trafficking is run under highly organized crimes structures to deceive, transport and trade the migrants (Burke, 2008). Despite these distinctions, human smuggling is nonetheless widely considered an unethical business because it has characteristics similar to trafficking in the legal sense. According to Içdyugu \& Toktas (2002), there are seven overlapping characteristics of smugglers and traffickers, namely: a local initiating smuggler, cashier, guide, local transiting smuggler, middleman, landman/shipman or airman and other helpers. The detail is stated below:

Local initiating smuggler: organizes the departures of irregular migrants from their localities and takes them from the previous smuggler and hands them over to another one who facilitates the illegal border crossing. Cashier: as an entrusted person, receives and pays out money between migrants and smuggler in the smuggling operation. Guide: knows the region or the borders very well and accompanies the migrants following the agreement between the smuggler and the migrant. Local transiting smuggler: takes the migrants from the border areas in the transit country and moves them to the departure areas in transit country. Middleman: takes the migrants from the person who brought them to the departure point to the next smuggler in the chain (usually landman, shipman or airman) who arranges the final trip to the point of destination. Landman, shipman or airman: arranges the irregular border 
crossings, sea or air passages, and organizes the port from which the migrants will depart and for the bribing of port employees at the point of exit. Other intermediaries, handymen, and other helpers: involved in diverse activities, help all other smugglers and perform secondary roles in human smuggling but not included in other categories (p.36)

For having a similar process and agents, there is still a risk for a smuggled migrant to get trafficked en route or at the destination (Salt, 2000).

In sum, it is evident that, in a practical sense, trafficked persons are often victimized and vulnerable to exploitation whereas smuggled migrants are regarded as clients (United Nations Office on Drugs and Crimes [UNODC], 2011). The relationship between a smuggler and a migrant is a service, provider-customer, whereas the traffickers are the controllers in the trafficking process through their abuse of power. These differing features have made each of those subject areas distinctive when studying their processes and their impact on the families left behind. Hence, the focus of this research project shifted away from human trafficking and it should be acknowledged that the research focus is limited to the case of human smuggling as a voluntary activity, and its impacts on families left behind.

\subsubsection{What are the myths about human smuggling?}

\section{(a) Myth one: Human smuggling operations are controlled by criminal organizations or networks}

One of the most discussed issues about irregular migration is related to the large and highly organized nature of agents and networks which facilitate illegal entry to another country's territory. This is because human smuggling is considered a transnational crime (Salt, 2000). This view is supported by Kyle and Liang (2001), who state that the barriers to smuggling people in risky situations, forging documents and relaxing the border controls, are only able to be managed by migration merchants represented by a range of people from travel agencies to transnational human smuggling rings. In their case studies about illegal migration from Ecuador and China to the United States, Kyle and Liang (2001) state that:

...such massive undocumented migrations would not be possible without a range of legitimate and underground migration merchants offering "packages" similar to those of travel agencies (p. 21) 
Accordingly, there is a belief that human smuggling activities are related to a multilayered network of international smuggling chains or drug cartels. Human smuggling is often portrayed as a multi-billion dollar industry which is controlled by transnational crime organizations and drug cartels (Pastore, Monzini \& Sciortino, 2006; IOM, 2000). These claims seem feasible considering the relatively higher cost of irregular migration compared to authorized entry to a state.

This myth has not gone completely unquestioned. There are also studies which claim that irregular migration is operated by independent individuals and small-scale groups which specialize in some aspects of the human smuggling operations. Some of those include the empirical research findings of Pastore et al. (2006) and Içdyugu \& Toktas (2002). Pastore and his colleagues (2006) criticize the idea that a few criminal syndicates control human smuggling activities by stating that this is "radically at odds with theoretical wisdom and empirical findings" (2006, p.97). Substantially different from the image of transnational operations, their study about human smuggling into Italy reveals that smuggling was done by independent groups or individuals working under business contracts. Human smuggling networks are "more disorganized and spontaneous" (Icduygu \& Toktas, 2002, p.36) than trafficking networks, and they operate in a way that different groups or individuals facilitate the different stages such as recruitment, transportation, crossing the border and sending to a destination (Içduygu, 2004). Along similar lines, Pastore and his colleagues (2006) argue that the operations of human smuggling are based on the parties which try to fulfil their tasks related to their competencies rather than taking central command. Human smuggling services are not monopolized in many cases, so that the migrants can even choose from an array of smuggling services (Bilger, Hofmann \& Jandl, 2006).

Other studies suggest the crucial role of brokers within the debate on the criminality of irregular migration. It is significant that public perception about irregular migration is substantially mirrored by the brokers and middlemen operating the human smuggling services. Lindquist et al. (2012) argue that 'a broker is not a fixed identity and must be considered in relation to location, time and power' (p. 8). According to these authors, irregular migration is facilitated not only by professional brokers, but also by amateurs utilizing their ethnic and family networks that exist across the border as well as transnational linkages. For instance, Molland (2012) 
finds that brokers are not from outside the village communities but from within a migrant's social environment through his study on cross-border irregular migration from Laos to Thailand. Therefore, the condition provided by these trusted brokers is similar to what anti-trafficking programs identified as 'safe migration' (Molland, 2012). In many cases the recruitments made by informal brokers, named as 'dilettante brokers' by this author, are disorganized. Departing from the notion that the smuggling operations are highly organized, these studies show different perspectives highlighting the role of informal brokers in the human smuggling process.

\section{(b) Myth two: Human smuggling is always related to debt and exploitation}

In other prominent literature about human smuggling studies how the financial settlement is done between the migrants and the smugglers is of importance. Reportedly, the cost of illegal migration is far too high for migrants and their families to pay by themselves. For instance, the smuggling fee from China to the United States ranges from $\$ 35,000$ to $\$ 70,000$ (Koser, 2008; Friebel \& Guriev, 2006). Not every smuggled migrant can pay this much in advance (Friebel \& Guriev, 2006). In such cases, the option for the migrants is to borrow the money from local moneylenders (Stoll, 2010), or become indebted to the smuggler (Friebel \& Guriev, 2006). A study in the West Guatemalan Highlands shows that the interest rate for borrowing money from the local coyote (local smuggler or moneylender) is 10 per cent and the debt can be doubled within the first year (Stoll, 2010). It has been suggested that being indebted to the smuggler can lead to further exploitation after arrival (Tamura, 2010). According to Friebel \& Guriev (2006), the smuggled migrants are "usually kept in 'safe houses' or sweatshops until the debt has been paid back to the smuggler or related business" (p.1089), and repayment duration ranges from six months to four years in the case of China-US migration. On the basis of these studies, it seems fair to suggest that human smuggling is associated with debts that increase the chance of exploitation.

Whilst it is agreed that human smuggling can lead to long-term debt and exploitation, some studies unveil rather contrasting scenarios of financial settlement in human 
smuggling. One of those scenarios is based on the findings that the smuggling fee is paid up front. According to Içdyugu \& Toktas (2002)'s study in the Middle East and Turkey, the smuggling fee is paid in advance before the departure. They state:

If there is no case of a "cash in advance" type of arrangement, the illegal migrants do not make the arrangements for their country of destination with the smugglers in their country of departure' (p.48)

Similarly, Koser (2008), drawing from his survey data with migrant households in Pakistan, states that the smuggling charges were primarily paid through savings, selling properties and jewellery. This is because investing a family member in smuggling is believed to be an investment in that they can expect a higher economic return (Koser, 2008). Due to the considerably expensive nature of the smuggling fee, unsurprisingly some families choose to borrow from relatives, friends or a loan shark (Bilgner et al, 2006) or be indebted to the smuggler (Tamura, 2010). However, Koser's (2008) findings lend support to the claim that smuggled migrants' debts are paid off by remittances after a particular time. On the basis of his household survey in Pakistan, Koser (2008) argues that remittances double the household incomes on average after two years, when the initial investment was also covered.

It should be noted that the price of human smuggling varies depending on the chosen destination, type of transportation and the level of guarantee ${ }^{9}$ (Bilgner et al., 2006). The consensus view seems to be that how families finance the irregular migration is contextual and varies according to different smuggling channels, the migrant's choice of destination, and the presence of different smuggling services.

As mentioned earlier in this chapter, the blurred line between human smuggling and trafficking seems to create more complexities in studying the nature of human smuggling operations. It is noticeable that whether human smuggling activities are entirely reliant on a loose network of individuals or groups rather than wellestablished transnational organizations depends on the context that migration occurs. Likewise, this section also highlighted the differing nature of how smuggling fees are settled between the smuggler and migrants, which often include a third party such as

\footnotetext{
${ }^{9}$ Guarantee means the agreement made between migrants and smugglers to make sure the migrants reach their destination. For example, in the event of a migrant being arrested by police during the journey, the smuggler will make the next trip free of charge or refund the total sum of money. The prices may vary according to different levels of guarantee (Bilgner et al., 2006).
} 
money lenders and relatives who provide the capital for the migration. In some cases, there evidently is exploitation and long-term control of the smugglers based on debt arrangements whereas some studies also show that the smuggling operations are often based on 'cash in advance' basics. Undeniably, the nature of the smuggling operation and paying for the smuggling play a significant role when studying the impacts of irregular migration because the social and economic consequences mostly depend on how these operations have been carried out. For this reason, it is essential that these myths are tested through local perspectives and experiences of both migrants and smugglers in order to better understand the impacts created by irregular migration in migrant-sending areas.

\subsection{Studying the impacts of migration on families left behind}

\subsubsection{New Economics of Labour Migration as a best lens to study impacts on families left behind}

The main earlier approaches to migration study were the neoclassical economic approach (or equilibrium approach) and an historical-structural approach. The former was influential around the 1950s-60s whereas the latter emerged around the 1970s80s (Castles \& Miller, 1995). As discussed by Wood (1982), the equilibrium approach and historical-structural approach suggest migration is an individual decision in order to maximize income, and is a result of structural demands between superior and inferior economies. At the micro-level, the neoclassical economic model has its focus on the individual's decision to migrate within given incentives and information available whereas it "disregards other migration motives as well as migrants who belong to social groups such as households, families and communities" (De Haas, 2010, p. 231). On the other hand, the historical-structural approach stresses the overall socio-economic and political structure of the 'world system' in which mobility occurs (Wood, 1982). Yet both models neglect the factors which influence individual choices and direction within migration behaviours. Therefore, Wood (1982) suggests a framework which integrates individual and structural approaches by shifting the unit of analysis to the households. 
This integrated approach has since been championed by the New Economics of Labour Migration theory which recognizes that migration is not simply a result of individual decisions, but instead is a result of decisions made by families and influenced by the social and cultural context and the wider community of origin (Massey et al, 1993; Stark \& Bloom, 1985). According to this theory, migration is considered a way to diversify income sources and to provide insurance against the failure of the primary income source of the family by sending one or more family members to other places to work (Stark \& Bloom, 1985; Stark, 1991). In addition, Taylor (1999) argues that "the migration and remittances have positive indirect effects on migrant sending households, easing capital and risk constraints on local production" (p. 80). This theory acknowledges the family or household as a unit of analysis which is vital in enhancing the understanding of migration motives, decisions and impacts.

Documenting the effects on families left behind is important because in many cases the people who move are likely to be breadwinners for the family (Antman, 2012a). Terms such as 'transnational families' (Asis et al., 2004), 'remaining households' (Gibson et al., 2011), 'families left behind' (Antman, 2012a), and 'the origin households or households of origin' (Osili, 2007) have been used interchangeably to mention the families or family members who have strong ties with their members working abroad. Previous analyses on the effect of migration on families left behind have been done by means of studying remittances and their relationship to the household's well-being (Start \& Bloom, 1985; Massey et al, 1993; Taylor 1999; Gibson et al, 2011), the emotional and psychological impacts on family members (Silver, 2002, 2014), changes in labour supply and role adjustment in the family (Zlotnik, 1995; Hugo, 2002; Hugo \& Ukwatta; 2010; Jones, 2013), and the impacts on dependants (Antman, 2010, 2012a; Hugo, 2002). All these studies found evidence that migration has significant social and economic effects on families left behind.

On the basis of available evidence, it is significant that NELM is the best available theory to study the social and economic impacts of migration at household levels. These studies also suggest that there is a need to explore the effects of both regular and irregular migration at the household level. Focusing on cross-border irregular migration from Myanmar to Thailand, this study attempts to explore the social and 
economic impacts in the case of irregular migration at household level through the NELM lens.

\subsubsection{Economic impacts of migration on families left behind}

A substantial body of literature on migration focuses on the economic effects of migration on families left behind. A number of studies found that international remittances generally have positive effects for migrant-sending families yet they also create inequality in migrant-sending areas (Taylor et al., 1996; Durand \& Massey, 1992; Massey \& Parrado, 1994). Hence, much of the debate revolves around how remittances are managed by families left behind.

\section{(a) Remittances and incomes}

Empirical findings on the contribution of international remittances to the economic status and well-being of migrant households have been documented by different researchers. Migration is an alternative source of income supplementary to the household's primary income source (Taylor, 1999). A number of studies have demonstrated that international remittances improve the living standards of, and consumption within, the family (Start \& Bloom, 1985; Massey et al, 1993; Taylor 1999; Gibson et al, 2011). Koc \& Osnan (2004) found that international remittances improved the welfare status of migrant families in the area of origin as they covered the major proportion of household expenses, and helped the family to purchase land and to invest. Piracha et al. (2013) found that remittances promote the chance of being self-employed among return migrants in Tajikistan. Drawing on their study in Bangladesh, Raihan et al. (2009) concluded that the chance of households being poor is reduced among households which receive remittances. Similarly, Adams (1991) finds that international remittances constitute nearly $15 \%$ of overall incomes in poor households, thus decreasing poverty among families in Egypt. On these grounds, it can be argued that in many cases international remittances contribute to the prosperity of remaining families and reduce poverty. 


\section{(b) Remittances and investments}

One of the critiques of international remittance is the impression that these are not used for productive ends. There is strong evidence supporting the notion that remittances are only used for consumption, household spending and land, but not on productive investments. A study about remittance expenditure patterns in Asia shows that households in Bangladesh and India spend more than 50 per cent of remittances on building houses and buying land (Stahl \& Arnold, 1986). Stahl and Arnold (1986) conclude from their study that saving from remittances is used for "consumption and for the accumulation of non-productive assets" (p.906) and remittances are generally not dedicated for improving productivity in rural households. Another study done with Mexican communities indicates that a majority of remittances are spent on food, household maintenance and other consumable goods (Massey \& Parrado, 1994). Although remittances promote the incomes and consumption of local families, they are not used in a way that facilitates the good of the local economy by improving production or creating employment opportunity (Durand \& Massey, 1992).

On the other hand, the dissidents of the argument that remittances are not used for productive ends highlight the varying nature of defining 'productiveness'. For instance, Koc \& Onan (2004) argue that the impression that remittances do not promote investments fails to acknowledge the differentiating nature of productive investments in various social and economic contexts. From their study in Turkey, they found that migrants invest more than other non-migrant counterparts, and as a result it was concluded that remittances provide higher propensity to invest. Similarly, Adams (1991) found that “...marginal budget shares to investment of migrant quintile groups are consistently higher than those of non-migrant groups" (p. 720). From his study, it was found that 73 per cent of individual migrant's expenditure was directed into buying agricultural or building land, where purchase of land was recognized as a 'good investment' in this study in rural Egypt. Therefore, the issue under scrutiny is to understand the means of productive investment in relation to remittance consumption.

\section{(c) Remittances, inequality and multiplier effects}

There is a notion that international remittances contribute to community development 
because of the multiplier effects through consumption and investments made within the community (Massey \& Parrado, 1994). As mentioned before, the main debate of whether remittances are used in productive means lies partly on the vague understanding of 'productive use'. When buying land and building houses are counted as investments, the proportion of investments through remittances increases substantially. The migrant families tend to tackle their most basic concerns such as building new houses rather than spending money on consumer goods, and certainly the amount of investments made by migrant households is higher than non-migrant households (Adams, 1991a). According to Stahl and Arnold (1986), remittances invested in housing can produce multiplier effects in the community because it boosts demand for building materials and creates new employment opportunities.

While acknowledging the benefits that remittances produce, it is also necessary to consider the negative impacts that they create. At a microeconomic level, many scholars agree that remittances create inequality in the community (Taylor, 1992; Adams, 1991b; Massey \& Parrado, 1994; Faeanani, 1995; Lipton, 1980). Likewise, a number of studies find that remittances generally have positive effects for the national economy and migrant-sending families yet they also create inequality in migrant-sending areas (Taylor, Argongo, Hugo, Kouaouci, Massey \& Pelligrino, 1996; Durand \& Massey, 1992; Massey \& Parrado, 1994). For instance, Massey \& Parrado (1994) in case of Mexico finds that housing and land prices rise according to the demand of families receiving remittances, and they become unaffordable for families receiving none. Along similar lines, Lipton (1980) argues that remittances are mainly spent to raise recipients' status through the consumption of imported goods and luxurious housing, which has no effects on the economic development within community.

These studies highlight both positive and negative impacts as a result of international migration. According to these studies, it is admissible that international migration has improved the consumption and investment nature of migrant households. However this in turn has a backlash effects - inequality among households in one area. 


\subsubsection{Social impacts of migration on families of migrants}

\section{(a) Role changes within the family}

There is a growing body of literature that points out the impacts on the household structure by the absence of one or more family members in the migrant households in sending areas. These role changes influence the decision-making in the families of migrants as it has a huge impact on purchasing household materials and children's education (Antman, 2012a). These role changes depend on 'who' migrates.

The first scenario in studying role changes focuses on male migration. As men are more likely to migrate than women, most literature focuses on management with the household affairs after the male breadwinner migrates (Antman, 2012a). For instance, a study about the migration effects on families in Indonesia shows that women often became the head of the household when their male siblings or husbands migrated (Hugo, 2002). According to this study, the proportion of households led by women in their study area was 66 per cent, compared to the proportion of households led by women in all of Indonesia which is 13.7 per cent. Accordingly, Zlotnik (1995) argues that women in Asian patriarchal family units were promoted to breadwinner status whether they migrated to earn money, or stayed at home to look after family when their husbands migrated.

The second scenario of the occurrence of role changes can be discussed in case of female migration. It is noticeable that participation of women in economic activities is promoted through female labour migration. As a result of this, women decisionmaking in the household is enhanced and they become able to secure income which helps to "actualize their roles" in the family (Pedraza, 1991, p. 322). However it is also notable that female migration usually comes at the cost of giving up the caretaking tasks for their family and children (Zlotnik, 1995). Although women are empowered if they are left behind, a study in China found that their well-being may be decreased because of the extra workload in the absence of their husband or children (Mu \& van de Walle, 2011). In accordance with their study with Chinese migrant households, $\mathrm{Mu} \&$ van de Walle (2011) found that despite investing more time farming in the absence of their husband or children, there was no improvement in women's decision making about the household's farming activities. Along similar 
lines, Hugo (2002) found that it was hard for women to cope with agricultural work in absence of their husbands who had migrated abroad. Doubtlessly, women's participation in migration also creates changes in family structure and the distribution of the workload on the remaining household members.

These studies show that the imbalances in undertaking household tasks are a consequence of the absence of one or more family members in migrant sending areas. While remittances contribute to the improvement of household assets, investments and living standards (Massey et al, 1993), the transferring of tasks has become a burden for many family members in the household of origin.

\section{(b) Migration and transfer of childcare duties}

Another focus of international migration's impacts on the family left behind is on the transfer of duties to parents remaining at home. For instance, Zlotnik (1995) argues that remaining household members have to undertake the tasks that women traditionally do, such as child care and household work. According to Asis and his colleagues (2004) men in the Philippines are forced to enter "into the world of 'women work' as reproductive work ${ }^{10}$ previously managed by their wives was transferred to them" (p. 206) while continuing in paid employment.

Additionally, a number of studies have found the transfer of childcare duties to grandparents in cases of parental migration. According to Pantea (2012), grandparenting is a family strategy to cope with the employment demand. This is more significant in case of migration because grandparents supplement the childcare work in absence of their migrant children (King \& Vullnetari, 2006). For example, Guo and his colleagues (2009) from their study in rural China find that 52 per cent of nonmigrant parents live with grandchildren. They find that "monetary support received by parents may be associated with more responsibilities such as childcare in the absence of middle-generation" (p. 549). As a result of this, Antman (2012b) reports that there are a higher number of incidences of physical and mental health issues with non-migrant parents who are left behind in sending area. Likewise, King \&

\footnotetext{
${ }^{10}$ Refers to doing household chores and taking care of family members in this context.
} 
Vullnetari (2006) argue that left-behind parents are vulnerable because of the lack of social support from their emigrant children, and therefore, are depressed and worried about their capability.

\subsection{Applying NELM to irregular migration process}

Irregular migration is one of the most significant topics in the field of migration studies which is always regarded as an important contributing factor to many countries' development. However, most literature on irregular migration has focused on its illegality and the situation of irregular migrants in the destination country. Not surprisingly, much of the literature portrays irregular migration as dangerous and an abusive phenomenon for irregular migrants, and brokers and agents as evil and exploitative. One of the reasons for considering irregular migration as an unpleasant and life-risking activity is because of the thin line between definitions of its subcategories: human smuggling and human trafficking. According to Salt (2000), human smuggling and trafficking in persons are similar in terms of entering a country without proper authorization, undergoing a risky journey, and the involvement of a third party.

It is noticeable that the processes incorporated in these categories are substantially different. In terms of the nature of the process, human smuggling is a one-off service which is based on agreement between smuggler and migrant, whereas human trafficking can often include long-term control of a trafficker exercising coercion and exploitation over the migrants (Davidson, 2003). Even if the situation started as smuggling, a person can end up being trafficked because smuggled persons often have little knowledge about what can happen during the journey or at its destination (Salt, 2000). Undoubtedly, these differing natures of smuggling operations are influential on the impacts on the families of migrants after participating in smuggling operations.

The typical view of regular labour migration is quite different and altogether more optimistic. In reference to the New Economics of Labour Migration theory, studies have found both positive and negative impacts caused by social and economic 
means. Through empirical studies, scholars find that international migration improves living standards, relative income, and the opportunity to invest in productive activities of migrant households in the area of origin (Stark \& Taylor, 1991; Taylor, 1999; Taylor et al., 1996). According to the New Economics of Labour Migration view, international migration produces positive effects in the migrantsending community yet, it is also notable that this may also create inequality in respect to other non-immigrant households in the same area.

In contrast, the studies about irregular migration seem to imply that irregular migration creates economic burdens on the families left behind. Studies into irregular migration often indicate entirely different scenarios such as labour exploitation and debt (Tamura, 2010; Kyle \& Liang (2001); Friebel \& Guriev, 2006).

The critical question here is 'how can these views be reconciled?' Should we see irregular migration as an unpleasant process or should we see it as an alternative way of migration which entails many positive impacts similar to those of international labour migration? Based on these critical questions, this study attempts to relate NELM to the case of irregular migration. Hence the ultimate goal of this study is to explore the processes of irregular migration and its impacts on families left behind through NELM lens

\subsection{Developing research questions and a hypothesis for this study}

This chapter discussed the significant aspects of irregular migration, human smuggling and human trafficking. Understanding these concepts is crucial because the impacts of human smuggling and human trafficking are very different. Therefore, to study the impact of irregular migration, it is essential to clarify the distinctions between those two concepts. Most importantly, local perspectives on these concepts should be taken into consideration when investigating the nature of irregular migration in a specific context; i.e., whether it is voluntary or the result of deception.

Many of the concerns of scholars about irregular migration focus on deception and exploitation by the brokers or local smugglers. Yet the studies have found that local smugglers in many cases are acquaintances or contacts of friends or relatives 
(Liempt, 2007; Pastore et al., 2006; Içduygu \& Toktas, 2002). This highlights the need to assess how migrants perceive local smugglers and the relationship between the migrants and the smugglers. From this point of view, understanding how the financial settlement is made between these two parties is essential if the conclusion that whether human smuggling is exploitative or helpful is to be drawn.

On one hand, international migration is seen as a family strategy to improve the income and living standards of migrant families, as suggested by the New Economics of Labour Migration perspective. Significantly, there is a significant stress on the household in the sending area both socially and economically. On the other hand, the literature about irregular migration is rather overwhelmed by 'myths' and most conclusions seem to dwell on its 'evil side'. As a result, the possibility of positive impacts accumulated by the irregular migration on families left behind has often been overlooked. Thus, reconciling these contrasting views on the process and impacts of irregular migration was my ultimate aim in undertaking this thesis. A number of myths about irregular migration which identified the process as always debt-related, dangerous and life threatening have been established in the public perception and policy discussions. These established myths seem to overshadow the reality about the impacts of irregular migration as experienced by the local community. Thus, the misunderstanding and confusion about irregular migration calls for a set of questions that needs to be answered.

Therefore, the primary purpose of this thesis is to investigate the process and impacts of irregular migration on families left behind in sending areas through a case study approach. The case study approach explores the process and impacts of irregular migration, as understood by selected local communities, through personal interviews and participant observation. Based on the result of the primary purpose, my hypothesis is that irregular migration in Myanmar conforms less to the "evil" image, than to the patterns of labour migration as described by the "New Economics of Labour Migration" theory. The main research questions posed to achieve these aims were: 1) What are the process and impacts of irregular migration on families left behind? And 2) How are these impacts different from the impacts resulting from legal migration? 


\section{CHAPTER III. METHODOLOGY}

\subsection{Introduction}

This chapter discusses the qualitative research methodology applied during the research project. First, I discuss the positioning of myself as a researcher and the issue of power in the research process. Following this is the discussion about the rationale for choosing a qualitative case study approach. This chapter also justifies the site selection, sampling method and the recruitment process. Following the discussion about how the data management and analysis has been performed, I also explain the anticipation of ethical issues, and the health and safety of myself as the researcher during the fieldwork.

\subsection{Positionality of the researcher and the issue of power}

I am a social worker currently studying for my Masters in Development Studies at Victoria University of Wellington. I previously worked with an organization called Kalyana Mitta Foundation (KMF) which promotes the development awareness of young people in Myanmar as a training coordinator for about five years. While working at the organization, my primary responsibilities included coordinating training programs, workshops, and field trips for young people from many states, and performing monitoring and evaluation (M\&E) for reporting purposes. As a part of organising these activities, I was also responsible for advocacy and communicating with partner organizations. These experiences provided me the opportunity to interact with people from various cultural and ethnic backgrounds, while the nature of my position included travelling and staying in different parts of the country. While working as a training coordinator, I was nominated as Secretary for KMF to initiate the application for KMF to be a legally registered organization. From that point on, my line of work was extended to dealing with local authorities and government officials for the organisation's registration process. I was mainly stationed in Yangon, the ex-capital of Myanmar, with frequent visits to different places in many parts of the country. 
My previous work provided me with many useful experiences which became valuable for conducting this research project. First, my social networks have been widened because I have worked in social development work for a long time, networking with different organizations around the country. I worked closely with organizations with different sizes and structures such as cultural groups, informal youth networks, Community Based Organizations, Local and International NonGovernmental Organizations (LNGOs and INGOs). This social network has been vital in gaining useful information and suggestions for my field research. In addition, my previous work contributed to my research advantage by improving my interpersonal skills and flexibility in different cultural contexts. Most importantly, it provided me with the interviewing experience and questioning skills which are crucial to performing my field work. Not only did my previous career help me to be ready for my research project, it also helped me to reflect on my position as a social worker while working with the local community members. I have always been aware that my position representing a local NGO always results in privileges in my fieldwork. It does so by creating power imbalances while communicating with local communities as I am regarded as someone with expertise and connections.

In this way, my previous experience encouraged me to be aware of the importance of reflecting on my positionality and encouraged reflexivity on myself while conducting my field research. Positionality here means social aspects in terms of gender, race, class and other axes of social differences that create relational positions (Chacko, 2004). Carling (2014) and his colleagues argued that "in research of migration, positionality is intertwined with the subject matter of research" (p. 38) as researchers need to position themselves in research settings. Funder (2005) argued that bias, power, and manipulation in the data generation process are unavoidable to some extent, yet these can be managed by ongoing reflection. Similarly, Nagar \& Geiger (2007) state that:

Reflexivity has often implied analyses of how the production of ethnographic knowledge is shaped by the shifting, contextual, and relational contours of the researcher's social identity and her social situatedness or positionality, (in terms of gender, race, class, sexuality and other axes of social difference), with respect to her subjects (p. 268) 
As Chacko (2004) argues "[positionality] sets the tone of the research, affecting its courses and its outcomes" (p. 52), thus it is important for the researcher to reflect on his or her positionality and power relations in all phases of the research project. Regarding my fieldwork, I am aware that my power was procured from many sources. My identity as a young local man and a student studying at a western university privileged me when dealing with the village authority and research participants for the fieldwork 'entry' and recruitment process. I was also aware that the 'entry' to the village was also facilitated smoothly because a government staff member who used to be stationed in the village tract introduced me to the village head and elders. He was influential not only with the villagers but also with the village elders. My strategy to minimize the power imbalances during my fieldwork included carefully choosing the clothing appropriate to the village setting and, rather than talking about my work and study, making conversation about my ancestry and native town.

\subsection{Insider/outsider divides}

Another commonly discussed issue in research fieldwork focuses on the insider/outsider divide. Being aware of disadvantages and advantages of being an insider or outsider-researcher is crucial in promoting the research's credibility (Unluer, 2012). It was not surprising that the research participants recognized me as a local because my native town is only fifteen miles distance from the village. Speaking the same language, sharing the same nationality and geographical location had fitted me into the category of 'insider' or 'native researcher' (Carling et al., 2014; Nowicka \& Cieslik, 2014). Matejskova (2014) stated that insider researchers have benefits such as having pre-established trust with the community, familiarity with the cultural and geographical situation and gaining thorough understanding of complex issues in the data analysis stage. While acknowledging these benefits, I should also be aware of the disadvantages of being an insider-researcher. Unluer (2012) noted that the disadvantages of an insider include overlooking the important information, personal bias and limitation to access sensitive information. As an insider-researcher, I took pre-cautions not to overlook any important information by taking observational notes and reflecting myself during my fieldwork and tried not to reflect my own bias during my fieldwork. I was also aware that I was the 'outsider' reflecting on the axis of ethnicity and native place, and most importantly the 
academic incentives for me to be in this place.

During my fieldwork, I was conscious that my positionality could affect the relationship with my research participants to some extent. Being a thesis student from a western university might seem a privilege for many locals, and it could be a distancing factor while communicating with my research participants. Although my intention was to keep my research process neutral and exclude power imbalances, I was, in many ways, unavoidably influential on the research process. For instance, I had total control of the sampling and recruitment of participants. In addition, I had the power to choose the questions and the venue for the interviews. To overcome these obstacles, I was reliant not only on my initial plan for the recruitment but also on my key informants' suggestions for the recruitment of the participants. Their suggestions were vital in choosing suitable participants who fitted into the categories. In addition, all interviews took place in each of participant's homes where they felt most comfortable.

In sum, researcher positionality and 'insider or outsider-ness' affects the research setting, and the relationship between researcher and research participants which can have considerable influence on the outcomes of the research project. While considering myself as an 'insider' during my fieldwork, I did not fail to recognize that other social differences such as language, ethnicity ${ }^{11}$, academic background and place of birth could cause my research participants to see me as an 'outsider'. While it was simply not possible to fully neutralize the power imbalance and personal bias during the research fieldwork, on-going critical reflection on myself and the research process has helped me to build a robust relationship with the research participants and reduce power imbalances.

\footnotetext{
${ }^{11}$ Shan ethnic language is mostly used among villagers because Nan Kham is a Shan ethnic village. Although my hometown was not very far from the village, I was aware that my inability to speak the ethnic language could be a distancing factor to some extent. However, I mentioned my grandmother who was a Shan while talking to the village's elders and head of the village, therefore making them feel that I belong to the Shan ethnicity in some way.
} 


\subsection{Qualitative research and case study approach}

For the analysis of the processes and effects of irregular migration, qualitative methods were utilized in this study. A qualitative research approach is used when a study is conducted "in a setting where complexity operates over time and where data on the multiple versions of reality can be collected" (Marshall \& Rossman, 2006, p. 53). Qualitative inquiry was appropriate for this study because it is necessary to understand the context of the study site and the perspectives of people in real life situations. Marshall and Rossman (2006) state that qualitative research is exploratory and descriptive and values the context which is vital if the researchers are to be able to understand the participants' perspectives in-depth in given social and cultural settings.

By using qualitative methods, this study seeks to understand the detailed explanations about the phenomenon through case study approach inquiry. Yin (1994) suggests that a case study approach is used to investigate "a contemporary phenomenon within its real-life context" (p.13). A case study approach provides a holistic view of an issue by focusing on detailed phenomena and the relationship of the subject being studied to the central research question in real-life situation (Denscombe, 2007; Creswell, 2003). Through an exploratory case study approach, this study aims to gain an in-depth understanding about the issue using semistructured interviews and participant observation.

\subsubsection{Site selection}

In qualitative case study research, a sample population or location is selected purposefully in order to produce rich information of the proposed issue which has the potential to be generalized to the rest of the population or area (Sandelowski, 1995). In case of irregular migration from Myanmar, it is more reasonable to study a rural population ${ }^{12}$ because the majority of irregular migrants are from rural areas (Hall, 2013). As such, the study area was chosen according to its potential to answer the

\footnotetext{
${ }^{12}$ Rural population accounts for 70.3 percent of overall population.
} 
research questions, the presence of my acquaintances and my familiarity with the cultural context.

Kayah State (See Appendix VIII), previously known as Karenni State ${ }^{13}$, is a state in Myanmar with a large emigration rate. It is located in the south-eastern part of the country and shares a border with Thailand in the East, Shan State in the North and Karen State in the South. The economy of Kayah state relies on agriculture, forest products, mining and remittances from migration. Decades long ethnic-armed conflicts within the state has meant it is the second least developed state in Myanmar. This conflict has also left thousands of Internally Displaced Persons (IDPs) within the state, while several thousands have fled to Thailand ${ }^{14}$ (United Nations High Commissioner for Refugees [UNHCR], 2014). Because of the easy access to the border, irregular migration to Thailand is active but not easily quantifiable (Kayah State Socio-economic Analysis, 2013). Different ethnic ceasefire groups have controlled many of the border areas between Kayah State and Thailand, and this has allowed smugglers to transport migrants across the border easily. Irregular migration to Thailand has been very common for the rural population of Kayah because of existing ties with refugees, and migrant friends and relatives already residing in Thailand.

Nan Kham village (see Appendix IX) in the northern part of Kayah State was chosen as a specific study area. It has a high rate of illegal migration through human smuggling to Thailand. The village has 92 households and a population of 494 . No official records of the number of people working abroad is available, but according to the village elders, $70-100$ people are currently abroad ${ }^{15}$. The main economy of the village is subsistence agriculture; i.e. both low-land and shifting cultivation. The agricultural practice in the village includes seasonal crop farming and rice farming. Being situated one mile away from the main road and neighbouring a much larger village, the villagers traditionally have no other income opportunity apart from

\footnotetext{
${ }^{13}$ The former name Karenni State has been changed to Kayah State by the government in 1951. According to National Population Census collected in 2014, the population of Kayah State is 286,738 and thus it is a least populated state.

${ }^{14}$ According to UNHCR (2014), the number of IDPs is 34,600 in 2012 and the number of refugees in refugee camps is 16,074 as of September 2013

${ }^{15}$ This number is very changeable because migrants tend to go back and forth from Thailand to Kayah State several times in a year.
} 
farming. While income from agriculture is only enough to feed the families, locals believe that remittances sent by migrant workers improve the living standard of the village community. Similar to many other villagers in Kayah state, people from Nan Kham village typically migrate to Thailand illegally assisted by friends and relatives who are already there. Migration routes from this village to Thailand are explained in Chapter IV in detail.

\subsubsection{Sampling method and Recruitment of the participants}

In qualitative studies, information about a phenomenon can be achieved by purposeful sampling (Cresswell, 2003). In this case study, a two-fold sampling strategy was implemented using maximum variation and snowball sampling procedures. Descombe (2007) describes snowball sampling as an effective technique for collecting an appropriate size of samples for small-scale research projects. The participants for the interviews were recruited through a snowball sampling method in which successive recruits are referred by former ones. By using snowball sampling procedure, the people who are eligible to participate can be recruited through a referral after each interview (Morgan, 2008). After this process has taken place, a maximum variation procedure was applied to direct the interview recruitments by identifying possible criteria for the participant recruitment relevant to the context.

As my field work commenced, the only criteria for recruitment was that the participants had to be a member of a family from which one or more members had been smuggled by the local broker. During my first trip to the village, I was introduced by a government staff member to two initial contacts; one person who used to transport migrants and another with three children currently working abroad. They became my key informants and the snowball started rolling through their personal contacts.

Sandelowski (1995) states that researchers need to identify what kinds of variation to maximize and minimize while employing maximum variation approach. Conducting interviews with the participants recruited through the snowball method before the maximum variation procedure would help the study to achieve information 
redundancy by identifying the demographic and phenomenal variations in the context (Sandelowski, 1995). Accordingly, I identified major variations for the recruitments. The main criteria for the participant recruitment identified after the first two interviews were as follows;

1). Households with one or more children working abroad

2). Households with husband working abroad

3). Households with wife working abroad

4). Households with no migrants

5). Returned migrants

6). Local smuggler ${ }^{16}$

7). Community leaders (elders, village head, religious leader ${ }^{17}$ and teacher)

In accordance with these categories, I recruited 16 participants in total from Nan Kham during my fieldwork. All interviews took place at their homes thus providing a comfortable environment for them. Not surprisingly, many participants fitted more than one category. For instance, the village head had no family members working abroad and the ex-transporter was also a returned migrant.

The two key informants were given explanations about my research questions and the intent of my research first, so they could help me explain to the successive participants. The documents I prepared for my fieldwork such as the Participant Information Sheet (Appendix V \& VI), the Information Letter to the Village (Appendix VII) and the Interview Guide were explained to them and I collected their feedback. By going through these stages, feedback was very useful in suggesting appropriate participants, introducing me to village elders and other community members, and assisting me during some interviews by translating into Shan language

\footnotetext{
${ }^{16}$ My initial plan was to interview a local smuggler. However, during my fieldwork, I found that no migrant smugglers exist in the village. I interviewed a man who used to transport migrants across the Thai-Myanmar border, but who does not consider himself a migrant smuggler. Although he does fit into one or more of the categories of human smugglers discussed in my literature review, I considered it would not be fair to name him as a local smuggler. Therefore, I used him as a transporter instead.

${ }^{17}$ I planned to interview the abbot of the village monastery. I visited the monastery but found out that his hearing was not good anymore.
} 
and vice-versa. The Preliminary Questionnaires (Appendix IV) were filled out by the participants prior to the interview to save time.

The first participants mainly fitted the category of 'household with children working abroad' with some overlapping categories. Then the direction of the recruitment moved to recruiting 'household with husband or wife abroad' and 'household with no migrants' to acquire varying responses to the research questions. Then the research was steered to recruiting 'return migrants' and finally to the teacher of the village for her opinion on the education of children in the village. A brief summary of the participants is given in Table 1 below:

Table 1: Summary of the categories of the participants

\begin{tabular}{clc}
\hline No. & \multicolumn{1}{c}{ Category } & Person \\
\hline $\mathbf{1}$ & Ex-transporter/ Return migrant couple & 1 \\
$\mathbf{2}$ & Household with children abroad & 5 \\
$\mathbf{3}$ & Headmistress of the village school & 1 \\
$\mathbf{4}$ & Household with husband abroad & 1 \\
$\mathbf{5}$ & Household with return migrant & 3 \\
$\mathbf{6}$ & Village elders/ household with children abroad & 1 \\
$\mathbf{7}$ & Household with no migrants & 1 \\
$\mathbf{8}$ & Village head/ Household with no migrants & 1 \\
$\mathbf{9}$ & Household with wife abroad & 2 \\
\hline
\end{tabular}

See Appendix II for further detailed summary of participants' profiles

The ages of the participants ranged from 25 to 72 and there were ten males and six females. All participants were from the Shan ethnicity and were Buddhists. The majority of the respondents were from the category of 'household with children working abroad', given that the large proportion of migrants were young people.

The recruitment was stopped when it reached the saturation point suggested by many scholars (Thomson, 2011; Morse, 2000), i.e; not getting new data or categories through the interviews. In my case, I stopped recruiting more participants when I 
acquired the same answers repeatedly from the interviews and the participant observation notes. By adjusting my interview semi-structured questions after a few interviews, the data collection process was directed to effectively answer the research questions.

\subsection{Data Collection Methods}

While conducting a case study, Yin (1994) suggests using multiple data collection methods in order to triangulate the issue being studied to improve the quality of the research. This study employed semi-structured interviews as a primary data collection method and participant observation as a secondary data collection method.

\subsubsection{Semi-structured interviews}

In qualitative studies, the researchers need to understand the perspectives of participants in-depth through face-to-face interactions (Marshall \& Rossman, 2006). Similarly, Descombe (2007) argues that in-depth interviews are used to collect data in respect of people's opinions, feelings and experiences. Therefore, the primary data of this study was collected through semi-structured interviews. Prior to the fieldwork, an Interview Guide (See Appendix III) which is guided by the literature on migration studies was developed in consultation with my research supervisor. The interview guide includes an opening question, main research questions and subquestions which were devised according to the literature. Although modifications were made according to the interview respondents, this initial question guide was very useful especially in terms of guiding me to focus on the purpose of this research during my fieldwork. The main focus of the questions was on how human smuggling was done in the local context, and the social and economic effects of irregular migration on the families of migrants.

My first interview was with one of the two informants whose children have been settled in Bangkok for many years. After that I interviewed my second informant who claimed himself as a pioneer going to Thailand illegally, and previously working as a migrant transporter. From that interview, I had an overview of how 
human smuggling was done in the local context and the impact of irregular migration on the households in the village in general. Eventually the first two interviews helped me identify potential participants who met my initial criteria. After interviewing these two people, the interview guide was revised in order to elicit relevant data to identify the economic impact on the households and the change in social aspects in the family (see Appendix III for the detailed interview guide).

On the basis of the interview guide, the initial question opens up the chance for participants to explain why, and how, their family members migrate. The main questions investigating the participants' opinions about economic impacts and social changes, especially in terms of the responsibility for household duties, the substitution of labour in farming activities and the level of participation in village affairs. These were asked to every participant except for the head teacher of the village school and the respondents representing 'household with no migrants'. Based on these main questions, probing and sub-questions were added to clarify and enrich the information in accordance with participants' responses. For instance, I asked the 'returned migrants' about their experiences being irregular migrants en route and at the destination place, Thailand. On the other hand, the two participants who were from households with no migrants were mainly asked about their reasons for not migrating and their opinions on the effects of irregular migration in general. Lastly, I interviewed the head teacher who had been working at the village school for four years to obtain her opinion on the issue.

In total 16 audio records of interviews were collected and the interview durations range from around 10 minutes to 53 minutes. All the interviews took place at the participant's home thus providing a comfortable space for them. All audio records were transcribed into the Myanmar language ${ }^{18}$ later using their names, making sure that all data were available only to me.

${ }^{18}$ Also known as Burmese 


\subsubsection{Participant Observation}

Alongside the in-depth interviews, this study employed participant observation as a secondary data collection method. Marshall and Rossman (2006) argue that participant observation is a common element in most qualitative studies and "immersion [through participant observation] in the setting permits the researcher to hear, to see, and to begin to experience reality as the participants do" (p.100). In studying the processes of irregular migration and its impacts on families of migrants, it is important to understand the socio-cultural context of the site in which the study population is located. Participant observation was used firstly to explore the cultural context, secondly, to collect ideas which could help in adjusting the research questions and thirdly, to capture the potential variations among research participants in order to increase the information richness of the study.

Participant observation was crucial in many ways for this research project. First, it gave me a chance to explore the socio-economic situation of the village in general. By going around the village, I took notes of the location of the farms, shops, mills and religious places such as the monastery and pagoda. This helped me to make sense when someone mentioned a place or a direction ${ }^{19}$ during the interview. Secondly, participant observation was also used as a way to blend into the community. To elaborate, there were two significant events I participated in during my fieldwork: one was a wedding reception and the other was measuring the village's streets. I was invited to a wedding reception of a return migrant and a woman from Loikaw, my hometown. The wedding was organized in Shan traditional style. For me, it was a chance to see who volunteered in decoration and serving food to the guests; because traditional weddings are significant events everyone in the village usually comes and helps. I also volunteered on one sunny day to help in measuring the village streets for a lighting project. I was at one of the informant's home when a staff member of the township Electric Power Corporation (EPC) ${ }^{20}$

\footnotetext{
${ }^{19}$ In Myanmar culture, people usually use directions (North, East, West, South) when mentioning a place. For example, one of my informants mentioned that 'there is a family in the southern part of the village whose family members never go abroad'.

${ }^{20} \mathrm{EPC}$ is the government-owned electricity distribution corporation.
} 
appeared. I offered to help with the road measurements because there were no young people but only elderly folks doing the job. Doing the measuring together with the village's elders provided me with a chance to be more familiar with them and to reach every street in the village.

Apart from participating in those events, I spent time with my key informants and visited their friends' and relatives' homes with them on days when there was no scheduled interview, or during the intervals between interviews. From those conversations, I got useful ideas for the adjustment of my interview guide and the variations for the participant recruitment. I did not take note of every conversation in front of them. Rather, later at night I wrote down what I saw and what I learnt in accordance with my research questions. This process gave me more insight into the study's topic, some of which could not be obtained during the personal interviews.

In general, my observational notes mainly include my reflections on my fieldwork, the observations of the interview participants, events in, and the infrastructure of the village. Initially, the notes were written in a notebook, but later they were transferred into a Microsoft file. The notes were organized under individual participant's name, events, and in some cases, highlighted to make sure they were well organized for further analysis.

\subsection{Data Management and Analysis}

\subsubsection{Data management and transcription}

An audio recorder was used to record the interviews. The interview recordings and transcriptions were saved in my personal computer which was password-protected. To prevent the unexpected loss of data, recordings and transcriptions were duplicated and stored on an external hard disk as well. To make notes retrievable and data manageable, logging the dates, names, time and place of data collection process were done in a timely manner (Marshell \& Rossman, 2006). The interview transcripts and recordings were stored systematically, accompanying the field notes of the researcher, in folders on my personal computer.

All interviews were transcribed into Microsoft Word and the interview numbers, date 
and place were noted in every record. A summary of participants' profiles (Appendix I) was developed using the information provided in the Participant Profile Sheet.

\subsubsection{Data analysis}

In qualitative data analysis, data are organised into codes and categories to form units of analysis whose meanings can then be interpreted (Chenail, 2012). As such, the transcribed data of this project, which are derived through voice recordings and field notes, were coded and divided into manageable segments in accordance with the research objectives.

The first stage of the data analysis is open coding where I created categories or codes by reading through the interview transcripts. In this research, the organizing of the main themes was informed by existing studies on the social and economic effects of migration on families of migrants through the lens of NELM. Therefore, in the next stage, codes were organized into themes, or broader categories, and developed into a hierarchical structure. To reduce the number of categories, some categories were placed under main theme or broader categories (Burnard, 1991). At this stage, using a pencil-and-paper strategy helps the researcher to juggle the words and makes it easier to see the big picture of the case (Bazeley, 2013). This pencil-and-paper strategy was useful for me in organising the main themes and sub-themes by highlighting and moving the cards around to match suitable categories. The following is the sub-theme analysis of the process and the effects of irregular migration on families of migrants. 


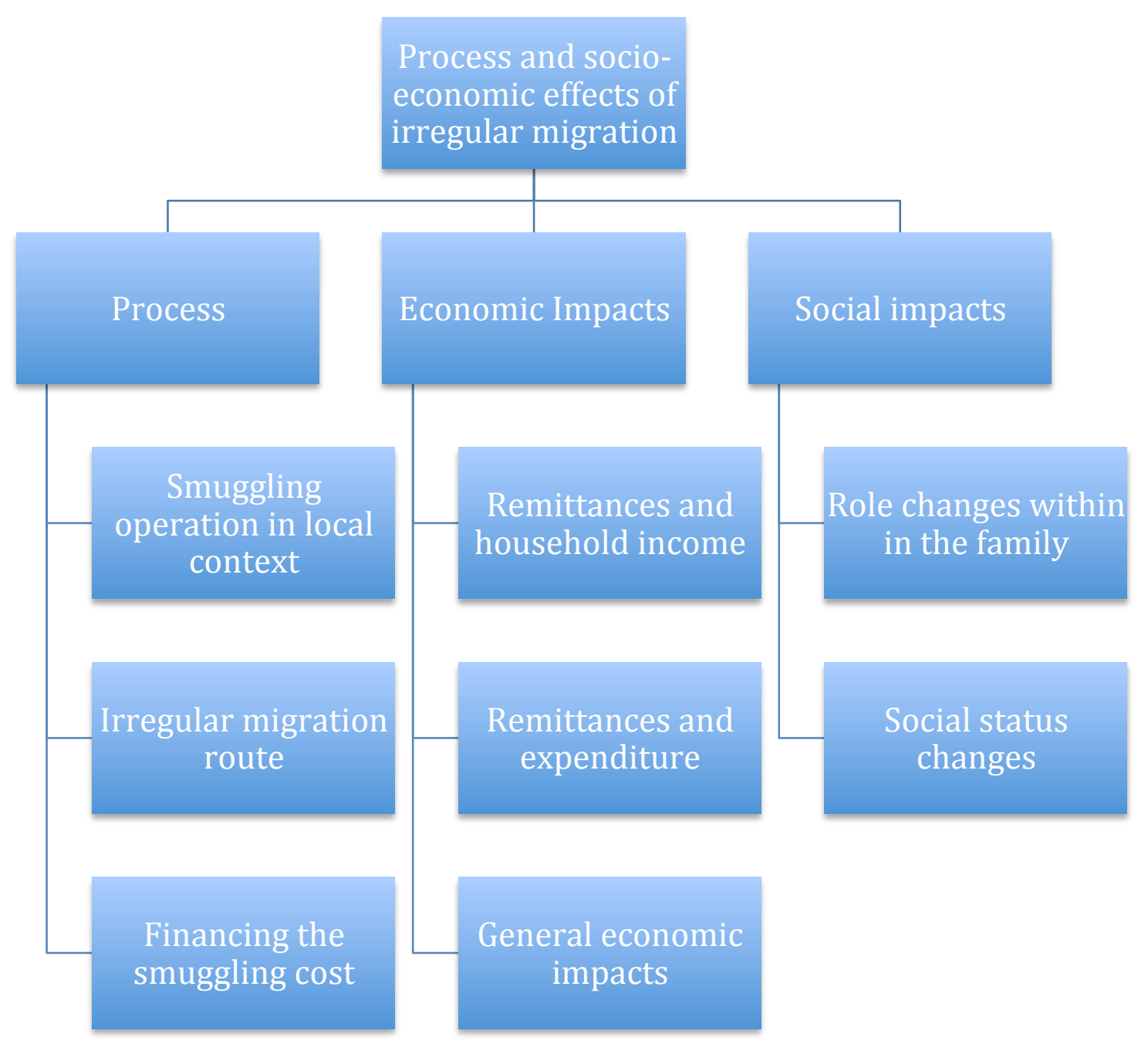

Figure 3.1: Sub-theme analysis of process and effects of irregular migration on families of migrants

\subsection{Ethical considerations}

This project was granted an Ethics Approval through the Human Ethics Committee of Victoria University of Wellington on 27 March 2014. Hence, this project has followed the guidelines provided by the Human Ethics Committee of Victoria University of Wellington to ensure that the project does not create ethical issues during the process. 
In addition, to avoid ethical issues during the research project, it is necessary for the researcher to anticipate ethical considerations and address them in the research plans (Creswell, 2003). Ethical considerations were anticipated in the preparation, implementation, analysis and writing up stages of the research project. Most importantly, this research aimed to ensure that the research findings benefited the study area and the individual participants (Creswell, 2003).

To avoid misunderstandings about the purpose of the research, an initial meeting with the village elders was conducted to clarify the purpose and to gain trust and credibility from the community. Acknowledging that human smuggling business is not an appropriate business in legal sense, the confidentiality of the participants is taken seriously throughout the project. I made sure that the research participants' names appear only on the audio recording and interview transcripts which are strictly available only for the researcher and the research supervisor. In addition, I negotiated with the participants about setting the venue and environment for interviews to make sure they were comfortable and secure. The collected data was maintained systematically in a lockable filing cabinet with access restricted to the researcher during the fieldwork. Assurance was given that recruitment would not include coercion, that the consent to participate in interviews was voluntary, and that the participants knew they could withdraw at any time. Participant consent forms were prepared in the local language in order to provide clear information about the project to the participants and to collect their consents. To maintain the anonymity of the participants, pseudonyms were used whenever I cited them in the research report.

\subsection{Health and Safety}

Until recently, conducting research in Myanmar was seen as 'politically sensitive'. Given that the new government is more open, I was able to conduct research without any security or political threats. I was aware that doing research on illegal matters could be risky. However, according to my fieldwork experience, irregular migration is not considered an unethical or illegal business at village level. To improve my security, permission was obtained from the village head prior to the research project by submitting the project information sheet. 
To prevent health-related issues, I brought a first-aid kit when I went into the field and located available health services beforehand. In terms of safety, I explored more about the social context in the target area, and learned more about culturally sensitive issues prior to my field visits. On top of that, consistent contact with my family, friends and supervisor was made to ensure my health and safety during my field research.

\subsection{Conclusion}

As a novice researcher, I anticipated potential obstacles relating to my positionality, and the power imbalance, in all stages of the research process. The fact that I was a local researcher was a great asset, helping me to avoid many potential problems that I had anticipated earlier. Nevertheless, challenges still remained for me conducting fieldwork research as an insider-researcher.

The study employed a qualitative case study approach to analyse the process and effects of irregular migration. The data collection methods included semi-structured interviews and participant observation to capture insights into the issue. Semistructured interviews provided a chance for face-to-face interactions between the researcher and the respondents. Conducting semi-structured interviews was effective not only to stimulate information richness for the study but also to foster the relationship between researcher and the research participants through personal interactions. On the other hand, participant observation was essential for this study in terms of building trust with the community, exploring geographical and cultural context and most importantly, having informal conversations with the villagers.

I followed the guidelines for qualitative analysis methods in my data analysis process where the naming of codes, themes or categories was informed by the literature on migration studies. The necessary skills for me as a student researcher in conducting data management and analysis were obtained through the coursework at the Development Studies Program. Therefore, I am proud to be a student researcher performing the fieldwork that addresses one of the important issues for my home country. 


\section{CHAPTER IV: PROCESSES OF IRREGULAR MIGRATION IN THE LOCAL CONTEXT}

\subsection{Introduction}

This chapter presents the findings which illustrate how irregular migration is understood in the local context, by exploring the opinions of the migrants' household members about smuggling contacts, motivation for migrating, and the migrants' experiences on the way from their villages to Thailand. To explore the process of irregular migration from Nan Kham village to Thailand, I interviewed an extransporter and four return migrants. This chapter has three significant sections: human smuggling in local context, irregular migration route, and the means of financing human smuggling.

\subsection{Processes of human smuggling in the local context}

One of the significant debates about irregular migration concerns on the nature of the human smuggling operation. On the one hand, the conventional belief about human smuggling is that it is always related to criminal networks or organizations. As a result, human smuggling is often portrayed as a life-threatening process which is operated by well-structured criminal organisations. For instance, Kyle and Liang (2001) argued that smuggling organisations essentially need a well-organized structure to manage agents or brokers at different stages of the smuggling process. In their study about the case of migration from China and Spain to the United States, they argue that:

it [organized human smuggling] is a trade positively correlated with greater border controls, which reduce an individual migrant's ability to "enter without inspection" without professional financial and logistical assistance (Kyle and Liang, 2001, p. 3)

Due to the expensive and illegal nature of human smuggling, it is always considered in association with transnational networks of criminal organizations (Pastore et al., 2006). On the other hand, there is a body of literature that highlights human 
smuggling operations that are run by individuals or groups at different stages of the operation (Pastore et al, 2006; Içduygu, 2004; Bilgner et al., 2006). For instance, Bilgner (2006) and his colleagues, through their study in Australia find that smuggling operations are not monopolized. Similarly, Leimpt (2007) finds that a number of individuals and agencies are unintentionally involved in the human smuggling process. Thus these findings clearly contradict the notion of the highlyorganized, criminal nature of smuggling operations.

To further investigate this, I interviewed the ex-transporter who was also the first pioneer of Nan Kham to go to work in Thailand. When I asked him how he started his business, he replied:

People knew that I saved money from Thailand when I came back to the village. They were inspired by my effort and started asking about possible ways to go. They said they would like to send their children too. I had no reason to stop them because there is no way to earn that much in the village. I just told them that if the kids worked hard, they could save good money by working there (personal communication, April 22, 2014)

U San was the first person from the village to go work in Thailand. He left Myanmar with his wife in 1995. They worked hard, saved money and stayed in Bangkok for a decade, with only occasional visits back home through illegal migration routes. Even before he started his own transportation business in 2010 he had been helping other villagers who wanted to go to Thailand by providing information about migration routes, and sometimes, taking them to the border without any fees. He said he was simply helping people. He reflected about his role in this smuggling operation:

I bought a 4WD in 2010. People contacted me to send their family members to the border. Most migrants I transported had already made contact with their relatives or friends living in Thailand. I just needed to drop them at the border and they went on using their own contacts. But for other migrants, I introduced my friends (brokers) who would help them to reach their destination such as Chiang Mai or Bangkok. (personal communication, April $22,2014)$ 
U San's job was to take migrants to the border and from there the migrants continued their journey by themselves. It is clear that he never considered himself a smuggler, but only as a transporter, for he did not receive any other fees apart from the transportation charge of 70,000 Kyats ${ }^{21}$ (70 US dollars) per person. This type of smuggling operation is common across the region. There were many transportation services, at that time, similar to U San's.

The narrative of the transporter was consistent with the experience of the return migrants I interviewed. It has been found that they managed their own journey following the advice of friends or relatives who had been on the trip before. I interviewed U Myo, a return migrant whose aunt was his helper. He went to a border town on a trading truck and contacted local smugglers there to take him to Chiang Mai, Thailand. U Myo said there was no contract between those smugglers and the migrants because both would be in jail if caught ${ }^{22}$. He said:

..they [smugglers] will be hurt three times more than us [migrants]. Say, if I am arrested, we will be put in jail and be deported. For them, as well as going to jail, their money and motorbike will be taken too. (personal communication, June 11, 2014)

His response indicates that there are no strings attached for getting service from the local smuggler. This highlights the equal status between the smugglers and the migrants. There was no bond or guarantee between them because they realized they were bearing equal risks in this process.

In accordance with my interviews and observational data, the findings of this study suggest that individuals, who were simply trying to make a living, ran human smuggling operations. This resonates with Molland (2012)'s findings through his study on irregular migration of Lao sex workers. In his study, he finds that the sex workers became recruiters facilitating irregular migration in cross-border migration

\footnotetext{
${ }^{21}$ The transportation to the border area is much more expensive than travelling to other cities because the drivers have to bribe officials at the checkpoints.

${ }^{22}$ This can be in many scenarios; they can get caught while crossing the border or while transiting from city to city or through random checks by Thai police in the city.
} 
from Laos to Thailand. Similarly, Lindquist (2012) finds that prominent informal brokers who facilitate migration come from different backgrounds ranging from teachers to government staff. This indicates the importance of an existing relationship between brokers and the village communities. Hence, the findings from this study about the human smuggling operations were significantly different from the portrayal of human smuggling in other parts of the world as highly-organized or well-structured mechanisms (Kyle \& Liang, 2001).

In addition, the findings confirm the conclusion made by Pastore et al. (2006) and Içduygu \& Toktas (2002) that human smuggling operations are coordinated by different individuals or groups in different stages of the smuggling process, and that these operations are not necessarily associated with criminal networks or organizations. Likewise, the responses of the return migrants in this case study suggest that there was no indication of being controlled by a smuggler during their irregular migration passage. Instead, migrants managed their own journey on the advice of return migrants and relatives, or friends already working in Thailand. In many cases, new migrants would accompany them when they went back after a short visit to the village.

According to this information, the migrants who give consent to be smuggled across the border fit into the category of "service types" 23 suggested by Liempt (2012). Evidently, the migrants U San transported already had an idea of how to continue their journey starting from the border area. Thus, his line of work was just to transport the migrants to the place they wanted to go. Therefore, his role in this migration fits into 'local initiating smuggler' or 'local transiting smuggler', as suggested by Icduygu \& Toktas (2002). In addition, the results of the analysis show that the smuggling operation from Nan Kham to Thailand is often based on the reputation of the smuggler, instead of the deceptive and exploitative nature of the smuggling operation which has influenced the literature on irregular migration.

\footnotetext{
${ }^{23}$ In his study about the inside perspective into human smuggling in the Netherlands, Liempt identified three types of smuggling: service, directive and negotiative type. In the service type, migrants decide where to migrate, whereas in the directive type, migrants follow the idea of the smugglers. And in the negotiative type, migrants consider the opportunities at the destination place and the trustworthiness of the smugglers. These types are also found in combination with one another.
} 


\subsection{Irregular migration routes}

Irregular migration involves crossing an international boundary without proper authorization and/or remaining in the destination country when the visa expires (Salt, 2000; Koser, 2010). As a result of weak border control, inefficient emigration policies and the significantly higher costs to access a legal migration channel, people choose to migrate illegally to countries such as Thailand and Malaysia by bribing the border military officials (Set Aung, 2009). Accordingly, my field research indicated different routes that migrants used to enter Thailand by illegal means.

One of those ways was to travel to a border town and get help from locals there to cross the border. In U Myo's case, he took two different trading trucks to reach the border. His words about his journey are quoted below:

When I reached the border, I asked some Kayan and Leeshaw ${ }^{24}$ people how to continue the trip. They took me on the motorbike because we could not travel in car at the place. They usually took us off the main road to avoid checkpoints. That's their livelihood! (personal communication, June 11, 2014)

According to his comments, it is clear that the responsibility of the local transporter was only until the border area was reached ${ }^{25}$. The migrants usually continued their journey by themselves. Once the migrants arrived on the other side of the border, they could continue travelling as an ordinary traveller. Even if they were arrested by the Thai police and deported to the border area, they came and looked for the same broker who sent them before.

That was similar to U San's description. He first recruited drivers who had driving experience to the border for his transportation business. He said he travelled from his village through Loikaw, Bawlake' and Ywathit until he reached Hua Pon Long. It was necessary to pay a cease-fire group and government soldiers as well as police at

\footnotetext{
${ }^{24}$ Ethnic minorities who reside near the Thai-Myanmar border.

${ }^{25}$ Migrants usually continue their journey from any of many border districts in Kayah State such as Mae Sal', Shadaw and Ywa Thit, etc.
} 
all the checkpoints through to the border. He replied to my question about how he managed to transport migrants to the border by saying

It was necessary to know how to do things before doing them. So I asked people who had done this before, especially about which groups to pay to be able to travel. I had to pay tax at KNPLF ${ }^{26}$ office to obtain the pass. And I also paid police when the car passed the town's gate. (personal communication, April 22, 2014)

Essentially, a service like this had to rely on good contacts with authorities who had control over the checkpoints ${ }^{27}$ on the way to the border. In the case of U San, he had to get a 'travel pass' from a cease-fire group's office at Loikaw to be able to travel to the border. People from Nan Kham village had different options to reach the border: for example, in U San's case, he used a 4 wheel drive pickup for his transporting business while $\mathrm{U}$ Myo travelled to a border village on a trading truck.

The following map illustrates the irregular migration routes identified by return migrants from Nan Kham village.

\footnotetext{
${ }^{26}$ Karenni Nationalities People Liberation Front

${ }^{27}$ There are more than 10 ethnic cease-fire groups in Kayah State. Those groups traditionally control access to border areas. The government checkpoint stations are normally placed at the entrance and exit of every township usually manned by government's soldiers or police. Likewise, cease-fire groups also have their own checkpoints on the way to the border. Therefore, to ease the journey to the border, transporters have to approach two or more parties to get permission separately.
} 


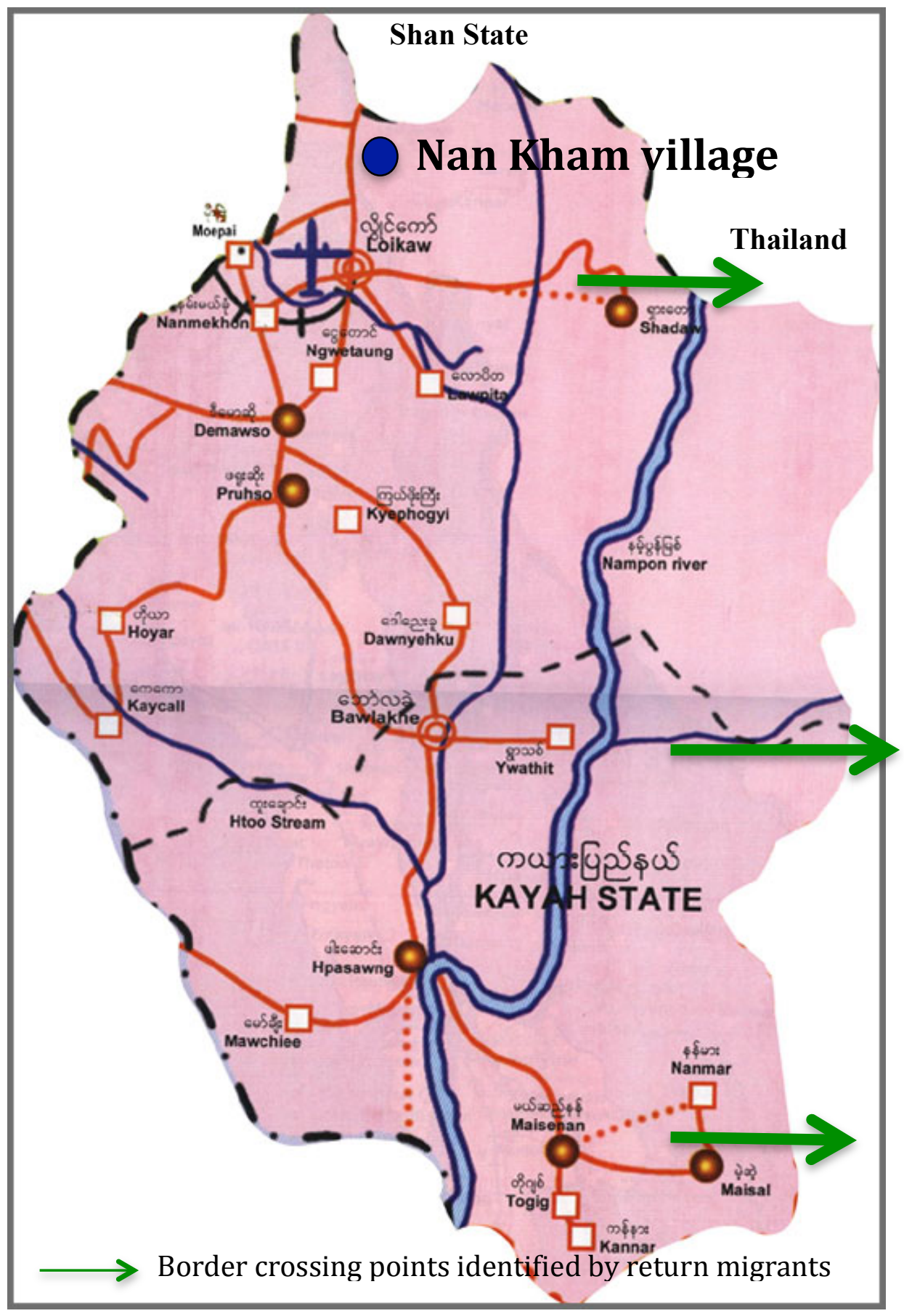

Figure 4.1: Irregular migration routes from Kayah state to Thailand

The study identified two significant ways to migrate illegally from Nan Kham to Thailand. In the first situation, as reported by the ex-transporter (or local smuggler), migrants contact a local initiating smuggler to smuggle them through the destination place. In this case, the local smuggler will take them to the border area and transfer them to another smuggler who is responsible for the rest of the journey. As mentioned earlier, these smugglers mostly are independent individuals who are trying to make their ends meet. The smuggling charge may vary depending on the 
type of service. In the second case, migrants make their own journey to one of the border towns or villages near the Thai-Myanmar border. They would contact the agent or smuggler ${ }^{28}$ who is then able to transport them to the other side of the border or to the destination cities. It is important to note that bribing the military personnel, police or ethnic-armed groups is often included in either of the cases. These confirm the argument put forward by Bilgner and his colleagues (2006) that migrants have the power to choose from an array of services available to them in smuggling themselves across the border. For this reason, smugglers play a significant role in facilitating the process by approaching appropriate persons or groups prior to the journey.

\subsection{Financing the migration costs}

According to McKeown (2012), the necessities accompanying legal migration have made informal brokers or smugglers become necessary for irregular migration, which provides the brokers with the opportunity to demand a higher price and deceive their clients. Thus, costs and ways of financing the smuggling services are also essential considerations in the study of irregular migration. Financial settlements in the irregular migration process are believed to be debt-related and exploitative due to the higher cost to migrate illegally (Kyle \& Liang, 2001; Içdyugu \& Toktas, 2002). Friebel and Guriev (2006) argue that often migrants cannot pay the smuggling fee up front because of the expensive nature of irregular migration. Therefore, they remain in debt to a local moneylender or smuggler for a period of time. Likewise, Set Aung (2009) argues that the cost of migration is naturally expensive and often creates a burden for the families of migrants. To explore whether irregular migration is debt-related or exploitative in the case of Nan Kham village, the cost and ways of paying the smuggling charge were investigated during the case study.

\subsubsection{The cost to migrate illegally from Nan Kham to Thailand}

\footnotetext{
${ }^{28}$ The narrative of U Myo suggests that these smugglers are just ethnic people who live around the border.
} 
This study identified that the expenses for migrating illegally across the Kayah StateThailand border ranges, according my participants, range from 200,000 Kyats to 400,000 Kyats (approximately equal to \$US200-\$US400 ${ }^{29}$ ). The cost of migration described by my participants was different from one family to another depending on the person or agents who helped them to migrate illegally, and the type of vehicle being used on the migration route. For instance, U San charged 70,000 Kyats (\$US70) to take migrants to Mae Sal, a border village where the migrants had to look for an agent to take them to Chiang Mai or Bangkok. Travelling from that border village in Myanmar to Chiang Mai or Bangkok costs around 6,000 Bahts ${ }^{30}(180,000$ Kyats) more. This calculation of irregular migration cost is consistent with the estimates of Set Aung (2009) ${ }^{31}$. The cost of migration in Nan Kham village is indeed expensive for my participants. Thus, the studied also identified the different ways of paying the smuggling fee which was considerably high compared to the cost of living in the village.

\subsubsection{Ways of funding the migration}

The most common ways of paying the smuggling fee or funding the migration identified by my participants included borrowing money from a money lender and selling property or jewellery. Having considered that Nan Kham's economy was based on agriculture, the migration cost was very expensive for the households of my participants. According to the interview respondents, it was common to sell jewellery and land to pay for the smuggling fees. In some cases, money was borrowed from relatives or a local moneylender. However, in this case study group, only one household claimed that they had to borrow from a local moneylender. According to one of the respondents, the interest rate for borrowing money ranges from 5 to 8 per cent per month. Although this kind of money lending service was illegal according to the 1990 Financial Institutions of Myanmar Law (Set Aung, 2009), it is not seen as illicit for local villagers. The financial constraints of migration costs had been lessened in many cases when relatives and friends provided crucial assistance for

\footnotetext{
${ }^{29}$ Based on the US currency conversion rate at the time of fieldwork.

${ }^{30} 1 \mathrm{Baht}=30$ Kyats

${ }^{31}$ In his study, he estimated that the cost to migrate illegally to Thailand ranges from 250400 US dollars.
} 
people from Nan Kham to migrate. For example, I interviewed U Kan, who was a return migrant about how he managed to go to Thailand. He said he followed his friends when they went back to Bangkok after a short visit one summer. He added

..I trusted my friends. They promised to find a job for me. They told me not to worry even if I could not find a job very soon. They said I could eat with them, live with them. (personal communication, May 9, 2014)

This is an example of where the burden of the smuggling fee was reduced with the help of friends who were already in Thailand. In addition, it was evident that my participants considered working in Thailand as a certain way that could return a profit in a short period. Therefore, in some cases, families sold land to finance the migration cost.

The story of another return migrant, U Myo, was different. He sold a gold necklace to pay for the smuggling fees. The money from selling the necklace was only enough for him to reach the border but his aunt picked him up from the border and took him to Bangkok. For many other families in Nan Kham, the ways of financing migration are similar. In most cases, younger siblings were usually sponsored by their elder brothers or sisters who were already working in Bangkok. For instance, U Tin talks about how all his children migrated to Thailand:

When everyone started going to Thailand, my children wanted to migrate too. My daughter was the first one to go. After she's been there for about three years, she called her younger brother to come over. Now, that son has been there for 2 years. When he visited home during last new year, our oldest son followed him when he went back. (personal communication, April 21, 2014)

In his family, firstly the parents supported their daughter to migrate, then that daughter financially supported the migration of her younger and older brothers. By the time they called on their siblings to come over, it was known that a job for them was already available and reserved, thereby saving time and money in looking for jobs. In this way, his family was relieved from the financial burden of supporting everyone who migrated. 
In sum, the findings from this study suggest that the expensive smuggling costs to some extent create financial burdens on families left behind in Nan Kham village. The families paid the smuggling fee by selling jewellery or land, realizing that migration was a kind of investment. However, there was no evidence that these were found to be related to further exploitation by smugglers or moneylenders. It was found in many cases that siblings or relatives supported some or all of the entire smuggling costs. Hence, there were no financial constraints for the remaining family members.

\subsection{Conclusion}

As the analysis has shown in this chapter, the smuggling operations in the local context is solely based on individuals working to meet their desired ends, rather than trying to establish a network of smuggling businesses to control every stage of the process. The findings here reveal the steps taken in the smuggling operations from Nan Kham state to Thailand, and these steps were clearly seen as simple and localfriendly. This highlights the similarity with the previous findings by Molland (2010) and Lindquist (2012) that the middlemen or brokers who facilitate the irregular migration in village communities are people who have an existing relationship with respective communities. In addition, relatives or friends often assisted the migrants in their journey to Thailand, and this made the migrants feel safer during this process. As the primary way to finance the migration was selling their property, or by contributions from siblings who had already migrated, no trace of long-term debt to, or on-going exploitation from smugglers or local moneylenders was found. It is clear from the above that the smuggling operations to Thailand from the context of Nan Kham village do not include coercion, or are not over-controlled by individuals or criminal groups. Further analysis will move on to the social and economic impacts of irregular migration on families left behind, as discussed in detail in the next chapter. 


\section{CHAPTER V: ECONOMIC IMPACTS OF IRREGULAR MIGRATION ON FAMILES LEFT BEHIND}

\subsection{Introduction}

This chapter discusses the findings of the economic impacts of irregular migration on families of migrants in Nan Kham village. As discussed in the previous chapter, there was no evidence that the smuggling operations were related to debt or longterm exploitation by the local smugglers. One of the reasons for this was because the smuggling fee which was inevitably expensive for the migrant households, was usually provided by friends, relatives or siblings. Thus, these supports relax the financial burden for those families for sending their members abroad. According to the New Economics of Labour Migration, migration is a result of the collective decision of family members and it has a profound economic impact on households in the area of origin (Yabiku et al, 2011). On the basis of this theory, this chapter explores the economic impacts on migrant households in irregular migration case in the area of origin. The data were collective through a qualitative analysis of the responses of my participants about their priorities and the use of remittances sent by their family members abroad.

\subsection{Remittances and household incomes}

To convey the analysis on economic impacts, it was necessary in my study to understand the amount of remittances received by the participants' households. Nan Kham is a small land-locked village and its economy depends mainly on agriculture. Almost every household in the village has at least one or two acres of farmland outside the village, which are mainly used for rice farming, and half an acre or one acre, next to their houses, which is utilised for cultivating seasonal crops such as beans, peanut, sesame, garlic and onions. A creek going through the middle of the village and a river passing by on the south made it possible to water their farmlands all year round. They worked throughout the year on the farm but the return from the 
farming was uncertain. I interviewed U Tin about the income of his household before sending his children to Thailand. He replied as followed:

Working on the farm throughout the year provides only enough to eat for a year. We never have money in our hands.... People go there [to Thailand] because yearly earning here is so low compared to yearly income there. They see it like this and it is true! In our household, we mainly farm corn and paddy. To do that, we still have to invest, and when we harvest, not much profit's left after subdividing the costs for seeds and fertilizers. We only have a little profit out of it. (personal communication, April 21, 2014)

Other respondents also said it was difficult to get hold of money because they had to invest their income from selling one crop into the next crop $^{32}$. Therefore, sending their family members became a popular way to increase the incomes of the households in the village, according to my participants. The returnees I talked to could save about 150-200 Bahts (4500- 6000 Kyats) ${ }^{33}$ a day after paying expenses ${ }^{34}$ in Thailand. That was significantly high compared to the standard daily wage of 2000- 3000 Kyats $^{35}$ for hiring a labourer in Nan Kham. And again, these labouring jobs in Nan Kham village were available only during the planting and harvesting seasons. Therefore, working abroad is believed to provide gross earnings for many families in Nan Kham village which can be used for housing, education and the daily expenses of households. When I asked one of my participants whose two daughters were abroad, about the reasons for sending members abroad, he replied that:

..Income through farming is only sufficient for food, not to build a good big house... when money is transferred here, it is multiplied by like 10 times than its value from there. (U Kyaw, personal communication, April 24, 2014)

\footnotetext{
${ }^{32}$ The lands are used for cultivating different crops throughout the year. For example, peanut and garlic are cultivated during summer while corn is usually cultivated in winter.

${ }_{33}$ Approximately equal to 4.5 to 6 US dollars

${ }^{34}$ Other studies reported lower wages. For instance, according to Turnell et al. (2008), it was stated that monthly earnings of a Myanmar migrant range from 1000 to 5000 Bahts in 2007 while Arnold \& Pickles (2011) reported the average wage is 74 Bahts in 2008 in Mae Sot.

${ }^{35}$ Equals to 2- 3 US dollars. Buying a meal in this area costs 1000 to 2000 Kyats (1-2 US dollars) depending on the types of food
} 
One participant even said that sending his family members leaves 'extra rice' because there are fewer family members to feed (U Tin, personal communication, 21 April 2014). For many households, the produce from their own farms is only enough to feed family members. While labour to work the farm mainly comes from family members, farming still needs substantial investment in terms of buying seeds, fertilizers and pesticides. The money for this investment is difficult to obtain the economic return of the farm is market dependent. The households that I studied have 4-5 members on average, thus providing an opportunity to invest one or two members to work abroad while the farm work was managed by the remaining family members. In addition to that, working in Thailand provides a monthly income whereas working on their own farms provides only a yearly income $\mathrm{e}^{36}$. Therefore for the participants, working in Thailand is more tempting than remaining in the village.

Not every participant talked readily about the remittances sent back by their family members. For those who gave answers, the amount of remittance received by their household ranged from 1,000,000 to 2,400,000 Kyats per annum, depending on the number of migrants who actually remitted back to those households. On average, a household could expect to receive 150,000 to 200,000 Kyats per month from a migrant working in Thailand. The amount of remittance received by the households of my participants varied according to the number of their members abroad and the marital status of those migrants.

This data shows the substantial increase of income among my interview participants' households. The remittances were considered an entirely extra income for my participants. Case studies in Mexico and China found that remittances have a negative impact on households' farm-related incomes (Taylor, 1992; Taylor et al., 2003). This was not the case for households in Nan Kham village. In my participants' households, farm work was taken care of by members remaining at home while some members went to Thailand to get extra income for the households. In this way, those households benefitted from having two income sources rather than relying only on traditional farming. Contrary to the myth that human smuggling

\footnotetext{
${ }^{36}$ Although varieties of crops are cultivated in different seasons, most of the yield from the farm is consumed in the household. Even when they sell at the market or to a broker, the money only goes into farm-related costs.
} 
creates an economic burden on migrants and their families through debt and exploitation, the findings in this study show substantial increases of income in my participants households while there is no indication of indebtedness. This discussion about remittances and income improvements leads to the following section on the analysis of the household's use of remittances.

\subsection{Remittances and household expenditure}

On the basis of the findings about the improvements to incomes mentioned above, this section presents the findings on households' use of remittances in Nan Kham village. Unlike previous research on economic impacts which were based on the investigation of consumption patterns through quantitative analysis (Massey \& Parrado, 1994; Gibson et al., 2011), this study uses qualitative methodology to analyse migrant households' use of remittances, while capturing the local context through participant observation. This study has identified that remittances were mainly used for housing improvements, investments for income generation and donations to religious institutions and village affairs.

\subsubsection{Remittances and housing}

First of all, it had been identified in my case study that the majority of remittances sent by family members abroad was spent on housing. As explained in the previous chapter, having good housing was a way of demonstrating economic status in the community. Therefore, according to my participants this had become the key motivation for people from Nan Kham to migrate to Thailand to work. For instance, 13 of my participants said that the remittances were used to build new houses on the same land. According to them, building houses was the most meaningful use of remittances because it was a 'visible achievement' for their members working in Thailand. This visible achievement is directly connected with the promoting of the social status of the households which is discussed in detail in the next chapter about social impacts. 
The responses of my participants about the use of remittances were similar in many ways. When I asked about their use of remittances, they replied "We will try to finish the house first, and might use the remittances as an investment later" or "People just try building new houses with remittances, they don't buy cars or other materials" These responses also implied that their use of remittances might have been different if there had been other ways to spend money such as buying cars, motorbikes or investing in some business.

For a small village like Nan Kham, there were not many ways to spend money. The village head agreed that the housing in the villages had improved within the last few years. When I asked about his opinion on the economic impacts of migration, he replied

..I would say the housing in the village has improved a lot in these 3-4 years. In the past, they all were made of thatch and bamboo ${ }^{37}$. (personal communication, May 5, 2014)

He mentioned the advancement of housing from wood house to concrete house as one of the economic impacts. According to the responses of my participants, building a new house using remittances had become a trend for the households in the village since 2000, when migrants started to remit money back for the building of new concrete-houses (Yoe-da-yarr Tike) in the village. The cost of building a Yoe-da-yarr Tike (See Figure 5.2) ranges from 7,000,000 Kyats to 15,000,000 Kyats (USD 7,000USD 15,000) depending on the size and materials. The highest remittances received among my participants' household was reported as 2,400,000 Kyats annually. Hence, it usually takes at least over two years to finish a concrete building for many households. On average, the participants seemed to agree that housing improvements was the first priority for the migrant households in Nan Kham to be done using the remittances.

\footnotetext{
${ }^{37}$ Typical traditional houses in Nan Kham use locally-made thatch roofs, wood frame and woven bamboo panels; or wooden walls and steel roofs (see Figure 5.1).
} 


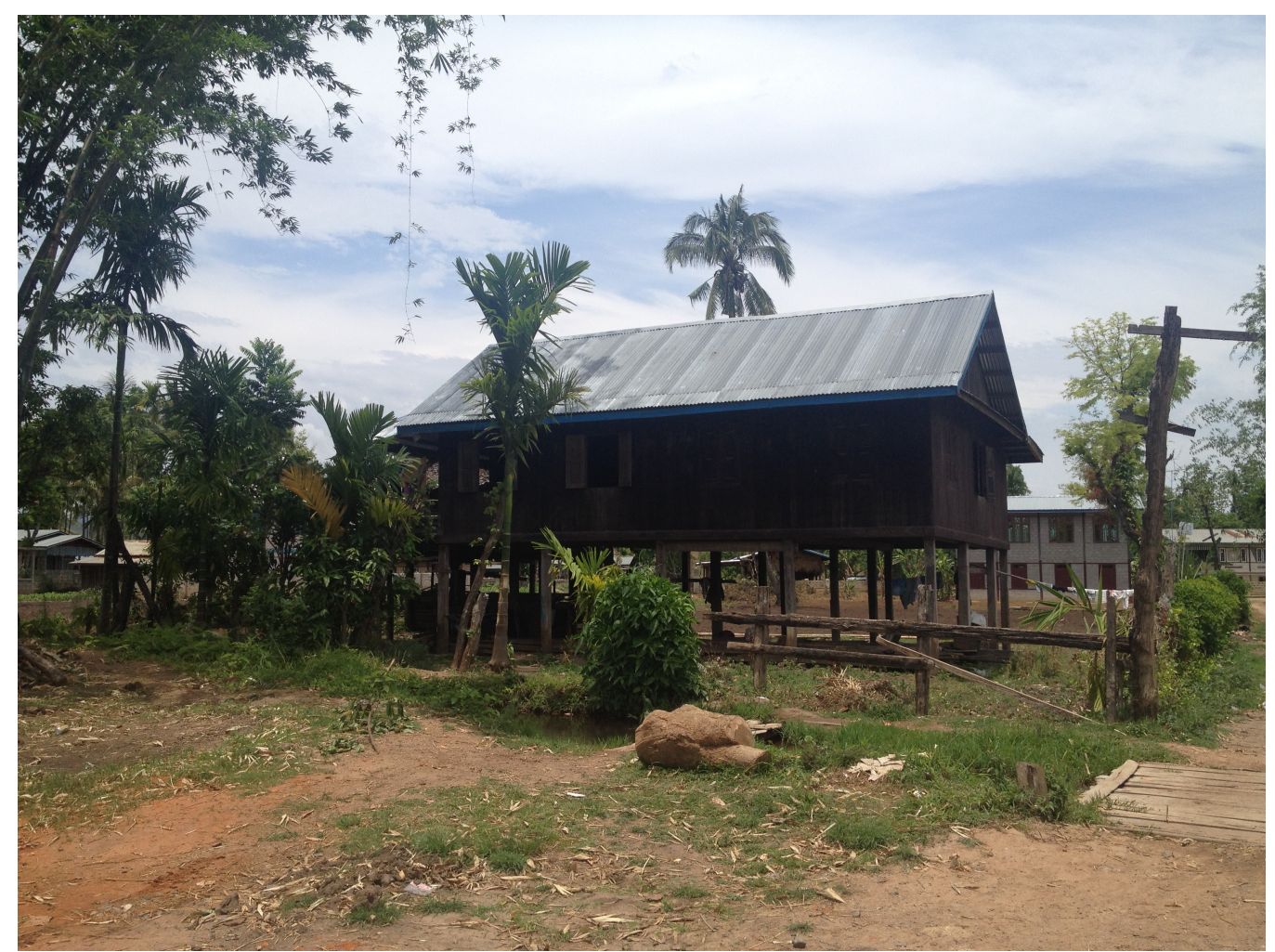

Figure 5.1: Traditional house

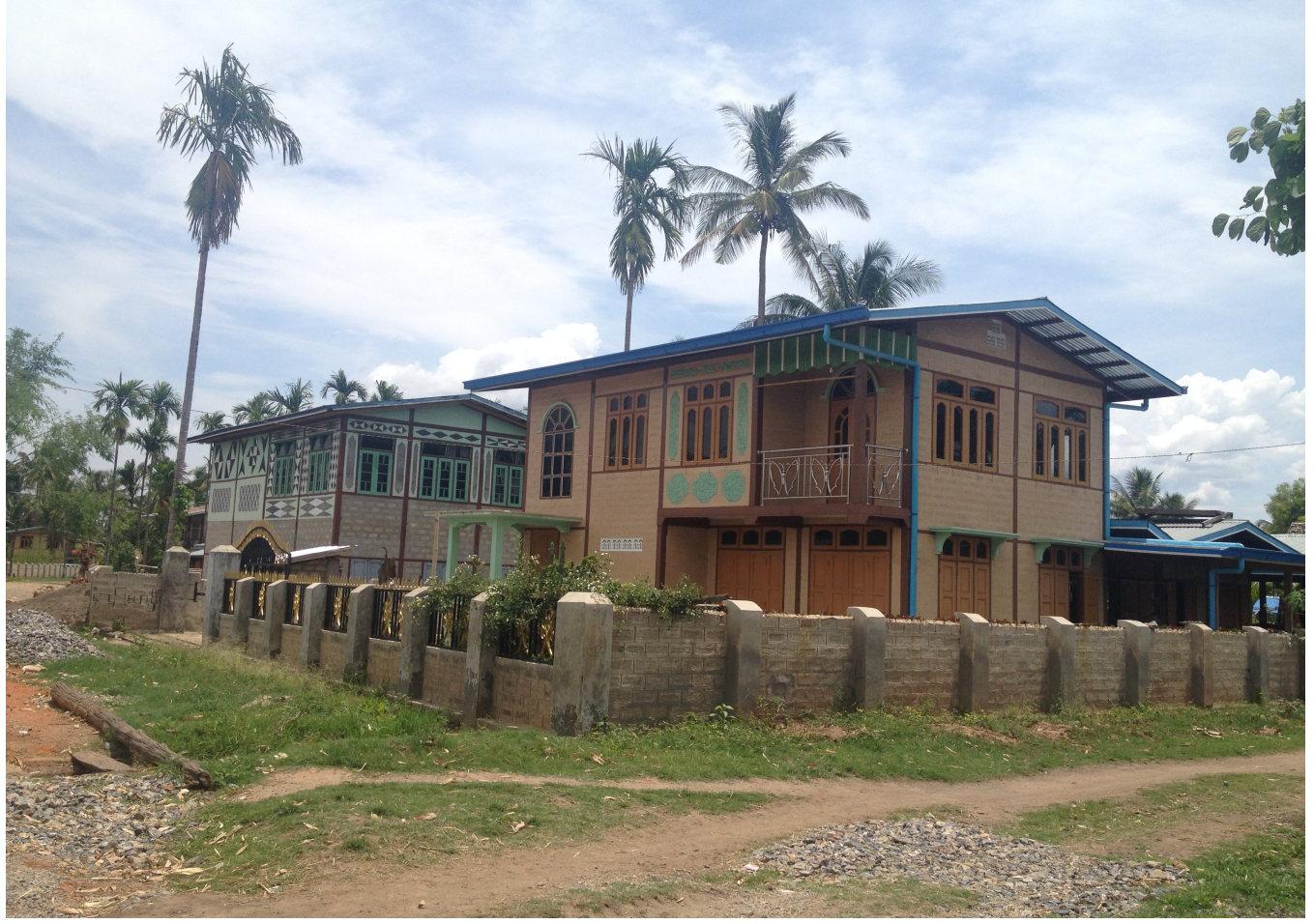

Figure 5.2: Some Yoe-da-yarr Tike(s) in the village 
The findings presented here agree with the fact that a large proportion of remittances were used for construction or repairing existing houses. This is consistent with the findings suggested by Adams (1991a) through his study in rural Egypt. During his study, he found that 53.9 per cent of overall remittances were spent on housing improvements, and drew a conclusion that remittances were used to solve 'their most immediate concerns' (p. 720) which was to replace their traditional houses with modern houses. This seems to reflect the case of Nan Kham village where housing improvement was considered a first priority for spending for my sample group. The findings showed that remittances sent back by migrant workers in Thailand were committed towards housing improvements for many years. As mentioned earlier, remittances were considered a surplus income for many families because most families also had income through their farm work. It was also significant that housing was considered not only as a state of well-being but also a way of establishing a economic status for many villagers, therefore, it seemed reasonable that housing was a most immediate concern for my participants.

One of the prominent discussions about the economic impacts of international migration lies on exploring its multiplier effects in the community. For instance, for Stahl and Arnold (1986), remittances invested in housing can produce multiplier effects in the community because it boosts demand for building materials and creates new employment opportunities. In this case study, the multiplier effects as a result of irregular migration occur in two ways. First, there is always a need for labour in the farm especially during the cultivating and harvesting seasons because of the absence of family members in some migrant households in the village. In this case, nonimmigrants from in or around the village are hired to work as a wage labour on the farm. In this way, the irregular migration influences the creation of job opportunities in agricultural works. Secondly, consistent with the finding of Stahl \& Arnold (1986), local people from around Nan Kham village can get jobs in building projects. According to this evidence from Nan Kham, it can be concluded that in addition to helping secure the alternative source of income for migrant families, irregular migration also provides job opportunities to non-migrant counterparts in and around the village. 


\subsubsection{Remittances and investments}

According to Adams (1991a) migrant households had a higher probability of investing in productive businesses than non-migrant households in rural Egypt. In his study, he compared the income and investment nature of 75 migrant and 75 nonmigrant households and concluded that migrants had a 'higher propensity to invest than do their non-migrant counterparts' (p. 720). In Haas (2005)'s opinion, spending remittances on housing, food and education could not be considered as 'unproductive or non-developmental' (p. 1274) because these improvements were vital factors for increasing their productivity and ability. However, this can create impacts on other non-immigrant households in the community. For example, Taylor (1999) argues

If NELM is correct, the poor households will face the most severe capital and risk constraints on investments in local production activities, therefore, the largest incentives to send migrants abroad (p. 79)

As a small village, there was a limited number of business opportunities for the people of Nan Kham, and the opportunities to invest were likely to be taken by return migrants who had enough capital.

Among the research participants, three of them reported the use of remittances as investments for future income generation. Given that Nan Kham was a small agricultural village, there were limited opportunities for migrant households to invest for future purpose. Nevertheless, it seemed that migration provided the capital for some of the return migrants to start up small businesses in the village. The investments made by returning migrants in this study were in 'trendy' businesses ${ }^{38}$, establishing mini-stores and trading seasonal crops.

Firstly, investing remittances in trendy businesses in the village was found in case of U San, who claimed to be the first person to migrate from the village. He owned one

\footnotetext{
${ }^{38}$ Trendy businesses, here means a kind of business which fulfils the demands of locals in a specific time-frame. For instance, the time that singing at karaoke was trendy among villagers in Nan Kham, U San set up a karaoke room in which people could go and sing at an hourly rate. After this was not popular anymore, U San moved on to doing another business.
} 
of the two rice mills in the village at the time of the interview. I asked him about how he tried to become a successful businessman in the village. He said

I could not buy this rice mill straightaway. I firstly bought some lands and a trailer jeep. And I also tried setting up a video station ${ }^{39}$ and karaoke at different times. I saved up my income and bought this rice mill. (personal communication, April 22, 2014)

U San said that working in Thailand gave him a chance for his family to save up and buy some land. It was an opportunity for him because there was not much cash circulating in the village; therefore, the price of land was still relatively cheap. He bought some land while he was travelling back and forth between Thailand and his village from 1995 till 2005. When he came back, he tried in various ways to improve his income. These included starting a small video station and karaoke which were fashionable in Nan Kham at that time. He also made money from hiring out his trailer jeep. He took the opportunity to do these trendy businesses from time to time according to the demand of people in the village. At the time of the study, his family had become one of the richest in the village. He acknowledged that it was all from his decision to migrate in the first place.

Secondly, the study also identified that the establishment of mini-stores in the village was an option of investing remittance money. According to two return migrants, Daw Hla and Daw Shwe, they started running mini-stores ${ }^{40}$ using the money they saved from working in Thailand, and their stores were the only stores in Nan Kham. For Daw Hla, the store was already there even before she went to Thailand, but her family could stock more varieties of goods in-store with the money she sent back. Her earnings from Thailand were spent on her son's education, buying stock for the store and farm. Daw Shwe had a slightly bigger store. She worked in Thailand from 2002 until 2010, and started running the store when she came back to Nan Kham.

\footnotetext{
${ }^{39}$ A video station in Nan Kham is a small cinema which plays movies for the villagers for money. Those video stations used to run at night time and host 30-40 people at each time. In Nan Kham village, there is no electricity provided by the government, so U San used a gasoline generator to show videos in his video station.

${ }^{40}$ These mini-stores mainly sell a range snacks and kitchen ingredients. Small home appliances, cosmetics and hand-tools for farming can be also available depending on the size of the stores.
} 
With her parents remaining in Nan Kham saving up the remittances for her, money was ready for her to start a mini-store on her return.

The last kind of investment from the remittances identified in the data in Nan Kham was investment in trading seasonal crops. As mentioned before, every household in Nan Kham village had a piece of land that was used for growing seasonal crops such as garlic, onion, corn and peanuts. According to the head of the village, some people could make money by buying these people's crops in the village at times and selling them back to bigger merchants. He added there was in fact, only one migrant household running this kind of brokering business because Nan Kham was just a small village.

In sum, this section has explained the type and nature of investments made through remittances in Nan Kham village. The findings from this analysis are consistent with previous studies which found that remittances usually generate positive impacts on the family left behind by means of promoting living standards and increasing household consumption, and providing capital (Taylor et al., 1996; Durand \& Massey, 1992; Massey \& Parrado, 1994). The types of investments identified here were investing in trendy businesses, establishing mini-stores and brokering seasonal crops. The most important finding to appear from the collected data was that earlier migrants had a higher probability in investing Nan Kham village, given that the return migrants were the only one who were doing businesses. As suggested by Taylor (1999), this promotes the motives of other non-immigrant counterparts from the same area to migrate. Taylor (1999) reminds us that the barriers for poor families to migrate include insufficient information and capital constraints. However, in case of Nan Kham village, irregular migration evidently provided alternative ways of getting knowledge, contacts and assistance from return migrants. Most importantly, it is significant that irregular migration plays an important role by providing alternatives to overcome capital and information constraints which are incorporated in regular migration in this case study. 


\subsubsection{Remittances as donations for religious events and institutions}

Donations or giving (known as Dana in Pali language) is a significant component of Buddhist culture in Nan Kham, and hence villagers of Nan Kham enjoy contributing to religious affairs especially when they had extra money. As mentioned in the earlier section of this chapter, remittances were seen as extra money because, for many families, the incomes from traditional farming practices were enough to feed the family members. While a migrant worker was working abroad, their family members usually gave donations or alms to the monks or the village's monastery because they believed doing so would bring good luck to their member abroad. Hence, this section focuses only on the type and amount of remittances used for such a category as identified by my participants and participant observation. According to data collected, the donation-related uses of remittances were identified for organizing the monastic ordination ceremony, donations for the improvement of the monastery and religious affairs.

According to my key informants, a substantial amount of remittance money was used for cash donations to the village's religious events such as the monastic ordination ceremony or Shin-byu, aside from building new houses and the daily expenses of the household. In Nan Kham village, Shin-byu were usually organized during the Myanmar New Year period-during April and May. The following is a quote from the interview with U San about how people came back to organize a monastic ordination ceremony for their children.

People working in Thailand usually come back to organize the monastic ordination ceremony. One ceremony like that just finished last month. It also depends on how old their children are. Say, if a migrant's son is about 10 years old, he would come back to do that. It costs around 10,000,000 Kyats each time because we have to invite people from our surrounding villages too. (personal communication, April 23, 2014)

According to U San, these events were organized at least once every two years where one family was responsible for a large proportion of the overall expenses, with the remaining expenses shared by many different donors. As mentioned in the previous 
chapter, the cost of organizing this kind of event was considerably high for many villagers. Therefore, it was barely possible without remittances sent back by family members abroad.

In addition to hosting the costly religious event, remittances were also used for contributions to the religious events ${ }^{41}$. Four of my participants mentioned using the money sent back by their sons and daughters. For instance, two of them said their children sent money mainly to donate to religious affairs. When I interviewed a mother whose daughter was working in Thailand, she said

She can't send much money. But she at least sends money to make donations. For example, she would send 1-200,000 kyats in October and another time in April. (Daw Kyu, personal communication, May 9, 2014)

According to Daw Kyu, her daughter mainly sent money for donations during sacred months in the Buddhist culture, realizing that the mother did not need to worry about living on her earnings. In the Nan Kham village monastery, those donations were used for the administration, maintenance, and providing food and accessories for monks. Additionally, the head of the village mentioned that families that had their members abroad mainly supported the renovation of the monastery and the new fences. He said

Our villagers working in Thailand support the village monastery especially for placing the new concrete fence and the construction of a new dining hall for the monks. (personal communication, May 5, 2014)

He added that many villagers volunteered for the construction, yet he believed those improvements were the result of his villagers working in Thailand. This highlighted the contribution of remittances towards religious donations.

In conclusion, this section highlighted the importance of remittances in terms of contribution to religious affairs and the improvements of monastery in Nan Kham

\footnotetext{
${ }^{41}$ Religious events in Nan Kham include hosting Buddhist prayer sessions at home, Dhamma chanting ceremony and celebrations on full moon days.
} 
village. In her study in Tonga villages, Faeamani (1995) found that donations to religious affairs and church groups accounted for a large proportion of remittances, and especially in one village, where the donations constituted 38 per cent of overall expenditure through remittances. This finding is consistent with the finding from the Nan Kham case where donations were considered an essential act for many villagers. There was no actual statistic about specific expenditure of remittances spend on donation in case of Nan Kham village. However, the interview responses implied that migrant families committed a substantial amount of remittances into the contribution to the village's religious affairs by making donations or organizing events. For my participants' households, remittances sent by their migrant members are vital in improving their living standards. Moreover, making donations was believed to bring good luck for their family members abroad, according to the interviews and participant observation. The findings here also suggested that remittances played a significant role in household's ability to contribute to religious events and donate to religious institution.

\subsection{Remittances and general economic impacts}

The data collected from this study concerning remittances suggested that households became confident about their economic status in Nan Kham village. The first and foremost reason for this was associated with the households' capability to build new concrete-houses through remittances. As mentioned in an earlier section, housing improvements was considered not only the most basic need but also a pride for many households. In Nan Kham village, Yoe-da-yarr-tike made up more than 80 percent of the total number of houses. Accordingly, it was not surprising that building a new house had become the main motivating factor for the returning migrants I interviewed. One of my participants proudly told me about how he became the first one to build a concrete house through remittances. He said

I worked and saved in Thailand, and I built the first Yoe-da-yarr-tike. After that, everyone [in the village] started asking me how they could go to Thailand. (U San, personal communication, April 22, 2014) 
This highlighted that he was proud to be the first return migrant to be able to build a concrete house with the money he saved while working in Thailand. It was also noticeable that 13 of my participants responded that building a new house was a priority for them. Undeniably, irregular migration provided a chance for many villagers to replace their traditional houses with new concrete Yoe-da-yarr-tike.

In addition to improving the economic status of households in the community, irregular migration also reduced agricultural expenses as well. I interviewed one participant whose three children were now abroad. He bought a small tractor to use in the farm with a lump sum of money one of his sons sent to him. He said "I can buy this tractor just because my son is working in Thailand." (U Tin, personal communication, May 21, 2014), and added that he could save the cost of hiring the machine from other people. Three households in my sample group reported that wage labourers were hired to substitute for the absent member. However, the wages were paid for by the money sent back from those absent members who were working in Thailand. This way seemed to be more sensible because their members could make a lot more money than working on their family's farm.

It was significant that for the individual migrant households, remittances provided a means for the improvement of assets, housing and standard of living. In the community it was evident that remittances enhance the local infrastructure such as the monastery as the amount of donations for religious events especially for the migrant households in Nan Kham village. It was also notable that, the improvements in such an area might not always create 'multiplier impacts' or 'community wide' benefits which has been the focus of debate around remittances and development. It has been found that in many cases, the expectations for spending remittances of my participants are placed not on the economic returns, but on the aspects of social status in the community and spirituality which is firmly grounded within the religions they belong to. Therefore, the results of analysis on economic impacts of irregular migration in Nan Kham village is directly connected to the social impacts, which is discussed in the next chapter. 


\subsection{Conclusion}

The findings from this study suggest that remittances an a direct the result of the irregular migration, had rather positive impacts in contrast to the negative image of the impacts of irregular migration which are 'debt-related' or 'long-term exploitation' for the families of migrants in Nan Kham village. The specific positive impacts explained here included the increased income, the improved housing and higher contributions to religious affairs. This chapter also highlighted the importance of good housing, and making donations for religious affairs in respect of the Buddhist cultural context in Nan Kham village. Findings here implied that remittances are also used for spiritual reasons such as donations, apart from the evident improvement of economic activities in some of the migrant households. The findings here also imply that the use of remittances by the return migrants has set up a good example of migrating to Thailand, therefore, promoting the other nonmigrants' motives to send their family members abroad. Irregular migration plays an important role by providing alternatives to overcome capital and information constraints which are incorporated in regular migration. Thus, the findings presented in this chapter contradict the myths about irregular migration being related to economic problems of the migrant households. Most importantly, it also showcased how international remittances' contribute to the general economic improvements of the migrant households by providing them an opportunity to acquire proper housing and reducing agricultural-related expenses. 


\section{CHAPTER VI: SOCIAL IMPACTS OF IRREGULAR MIGRATION ON FAMILIES LEFT BEHIND}

\subsection{Introduction}

This chapter discusses the second research question: The social impacts of irregular migration on families of migrants in the area of origin. Previous studies about irregular migration have had an evil image rather than its actual impacts in the area of origin. In order to assess the social impacts, I explored the changes in my participants' social aspects in terms of transfer of traditional roles and duties between husband and wife, and transfer of childcare duties. Furthermore, the changes in the social status of migrant families in the community are also discussed. In this chapter, it is argued that locals do not perceive irregular migration as evil or even as an illegal type of livelihood, but as a way to improve their household income, to be able to have a good reputation in the community through making donations and by enabling them to pursue a higher living standard. I also discuss changes in the households in the absence of their migrant members. This chapter is divided into two main sections where the first section analyses the impacts on left-behind family members of migrant households in respect of their roles in the family. The second section discusses the broader social impacts by highlighting the changes in social status as a result of irregular migration.

\subsection{Adjustment within families in the absence of one or more family members}

Previous studies had found that in a traditional agricultural society the absence of a family member as a result of migration has a significant impact on roles within the family as well as on migrants' households' labour aspects (Hugo, 2002; Mu \& van de Walle, 2011). It has also been agreed that separation as a result of international migration creates profound impacts on family members remaining at home in the area of origin (Yabiku et al., 2010). It is notable that men were more migratory compared to women and, in patriarchal societies, women often became heads of the household when their husbands migrate (Hugo, 2002). Supporting this argument, 
Antman (2012a) added that these changes had had major effects on household's expenditure patterns and education choices for their children at home. Studies also highlighted the changes in families over time by international migration, especially when women migrate to work. For instance, Zlotnik (1995) argued that women's status in the family was promoted to breadwinner status because their participation in economic activities was enhanced through international labour migration. On the basis of this literature, this study analysed the role change and labour substitution within migrant households through the responses of the research participants.

\subsection{Role changes within the families}

During the data collection, the 14 participants ${ }^{42}$ were asked questions about changes in their family in terms of household management and labour contributions to farm work due to the absence of their children, husband or wife. The responses from the participants and the records from participant observation indicated that many experienced significant impacts of migration on both the migrants and family members left behind within the family.

\subsubsection{Understanding women as more financially productive}

Traditionally, women's status in families was believed to be financially inactive (Zlotnik, 1995) and male migration is believed to be more economically beneficial to remaining households in area of origin (Yabiku et al., 2010). Although conventionally considered to be economically inactive, women have often become the bread-winner of the household as a result of international migration (Zlotnik, 1995). Pedraza (1991) from his study about the role of women in migration argued that as a result of women's participation in labour migration:

Patriarchal roles in the household were transformed, the women's self-esteem was heightened, their capacity to participate as equals in household decisionmaking was enhanced, and they secured more income with which to actualize their roles (p. 322)

\footnotetext{
${ }^{42}$ Total number of participants is 16 but 2 do not have their members working abroad
} 
In Nan Kham village, women were conventionally expected to take care of household chores, children and elders at home while men worked outside on the farm. Nevertheless, this scenario generally occurred only before migration to Thailand became popular among villagers.

One of the noticeable findings from this study was that female migration was considered to be more financially beneficial for the households in case of international migration from Nan Kham Village. The majority of my interviewed participants mentioned that it was more financially beneficial to send women than men. The collected data revealed how women are given more preference to migrate to Thailand to work, although it was a common phenomenon that both young men and women tried to migrate to Thailand 'as soon as they are old enough' (U San, personal communication, 21 April 2014). According to the head of the village, around 70 people were working in Thailand, of which the majority were young women under 30 years of age. The opinion of $U$ Kyaw, the father of two daughters working abroad, is quoted below:

..It is not so beneficial for men to work in Thailand. I think only one out of ten will behave well. Some men just go there and spend money with friends. If they drink and have fun there, there is no way that they can send money back home. Most male migrants are just like that. Women are different because they are a bit more economical and try to save money. (personal communication, April 24, 2014)

In his opinion, sending women was better than sending men, based on the assumption that men had more chance to drink and hang out with friends than women. $U$ Tin, who is the father of three children working abroad, reflected on $U$ Kyaw's comments and said

As far as I know, girls save more than boys. Some of the boys went and came back with bare hands. They could not save much. Sometimes, their savings were only enough to cover their trip back home, so that they came back and started working on the farm again... Yet, it also depends on each person too. (personal communication, April 22, 2014) 
According to these responses, it was more preferable for families to send girls than boys in Nan Kham context because there is a belief that women behave better than men do abroad. It was suggested that men usually spend their earnings by drinking and hanging out while women mainly focus on saving their earnings. Although women were traditionally considered to stay at home, they were understood to be more productive as migrant workers according to my participants.

The findings from this case study suggested that woman's role changes from economically inactive status to major financial contributors of the households. On the basis of available evidence, it could be concluded that international migration provided an opportunity for women in Nan Kham to be the major financial supporter of the migrant household on the basic of my interviews and participant observation.

\subsubsection{The migration of married woman and the transfer of traditional duties to the partner left behind}

Another significant finding from the data analysis was the transfer of traditional duties to the husband left behind when the wife migrated. When women in Nan Kham moved to Thailand to work, their traditional tasks were passed on to family members especially their husbands who remained at home, according to my participants and observation data. This impact on the family left behind was more significant when a married woman moved abroad.

I interviewed U Kan whose wife is currently abroad. When I visited his home for the interview, he was cooking dinner. At the same time, he was shouting to his five year old daughter who was taking a shower just outside the kitchen. I waited for him for a while and after that we started talking about the changes he had noticed ever since he was alone at home with his daughter. When I asked him whether he faced any difficulty doing household chores alone, he replied

Doing these things [household chores] are not difficult for me. I have done the things like taking care of the kid and cooking, since I was young. She is a good kid too. (personal communication, May 9, 2014) 
He mentioned no difficulty doing the household chores during the absence of his wife. However, noticing that women in this village always undertook household chores, I prompted him by asking about the difference in managing these household chores after his wife left. His reply to my question was:

Imm [Yes].. there are some changes actually. It would be more convenient if my wife had been here at home. After I have finished doing my farm work, I can just come back home and eat. But without her, I have to come back and cook for myself. (personal communication, May 9, 2014)

U Kan and his wife had worked together in Thailand before their daughter was born. He said his wife left for Thailand again when their daughter was 1 year old. During the interview he seemed to be hesitant to talk about difficulties he faced in the absence of his wife. He said if he went abroad instead of his wife, she would not be able to take care of the farm. If he remained at home, it was more efficient than his wife remaining because he could take care of both household chores and farm work. However, that came at the cost of bearing more tasks than before for $U$ Kan. This is an example of the burden on a husband in the absence of his wife.

This case highlighted the burden that a man needs to bear in the absence of his wife as a result of migration. This finding seemed to reaffirm the findings of the study conducted by Asis (2004) and her colleagues who found that husbands of the Filipino migrant women had to manage domestic work in the absence of their wives. In this family, the husband's role was shifted to doing household chores and childcare duties which previously belong to his wife.

\subsubsection{The migration of married men and the transfer of traditional duties on the partner left behind}

Previous studies have indicated that a wife's autonomy at home is improved as a result of her husband's migration (Antman, 2011a; Yabiku et al., 2010). Yet a consequence of this was that women had to bear an extra workload in the absence of 
their husbands who migrate (Mu \& van de Walle, 2011). A significant finding in this study on the role changes within a family related to the wife's role change in the absence of her migrant husband. I recruited a woman who remained at home in the village after her husband and son migrated to Thailand through snowball sampling. My intention was to learn about her experience in managing the household alone in the absence of male family members.

Daw Yin was in her early 40s and could not speak Burmese ${ }^{43}$ very well. Therefore, my key informant U San helped as a translator for some of her responses during the interview. Her husband went to Thailand 10 years ago and divorced her not long after he arrived there. She sent her 18 year old son to Bangkok two months before the time of interview. I asked her about the difficulties facing her while she was alone at home. U San translated her reply as below:

A bit more tired than before from doing farm work and the home garden... Normally, the other thing I have to do apart from farming is voluntary work called on by the village community, such as cleaning the monastery compound. Because there is no man at home, I have to go to village meetings by myself as well. If my husband had been there, he would go to participate in voluntary activity representing our household (personal communication, April 23, 2014)

She said that it was men's responsibility to participate in village affairs by representing the household while women take care of the household chores. Nevertheless, when there was not any man to take part in these affairs, it became her responsibility to do so. In addition, doing household chores, farming and nurturing the kitchen garden ${ }^{44}$ were her responsibility because she was alone at home.

In the case of a wife left behind in Nan Kham village, it is evident that women gained the status as a head of the household and improved decision-making in household affairs in the absence of their husbands. Nevertheless, it is noticeable that

\footnotetext{
${ }^{43}$ Burmese is the official language in Myanmar and belongs to the majority Burman people.

${ }^{44}$ In many households in Nan Kham, there is always a small piece of land beside the homes which is used for planting seasonal crops such as sesame, peanut, garlics or onions.
} 
these status changes come with the burden of taking on more responsibility, consistent to the findings of $\mathrm{Mu} \&$ van de Walle (2011) through their study with left behind woman in China. They found that although left behind women's decisionmaking within the household was improved, it was a struggle to bear the workload relating to household chores and farm work at the same time in the absence of their husbands.

\subsubsection{Parent migration and transfer of duties to grandparents}

Antman (2012a, 2012b) found that the impacts on left-behind parents at home include more incidences of physical and mental health issues with those non-migrant parents. Another type of role change within the family identified from the data was the transfer of responsibility from migrants to their parents in Nan Kham village. As mentioned in the methodology chapter, the majority of my participants ${ }^{45}$ were parents of migrants who were abroad at the time of the interviews. During my participant observation, I found that many migrants chose to leave their children at their parents' place, and that was a common phenomenon for many migrant households. When I interviewed them, I stressed the questions relating to babysitting tasks and managing household chores at the same time. I interviewed Daw Tuu, who is a 63 year old and whose three sons were working abroad, only two of whom were making regular contact and supporting her. Her youngest son came back and left his four year old daughter in her care six years ago. Her response was quoted below:

I don't need to do any labouring work but washing and cooking for my granddaughter and myself. No heavy jobs whatsoever... My youngest son is in Thailand now. He got married in Thailand after he's been there for four years. He's got a child after another two years. He came back and left his kid at home since she was six months old. She is now seven years old now. I was the one taking care of her until now. They [her son and his wife] send money regularly for their daughter and myself because I can't do any jobs while taking care of the kid. (personal communication, April 23, 2014)

\footnotetext{
${ }^{45} 6$ out of 16 participants
} 
She said she did not have to worry about any financial matters while remaining in the village. She had been taking care of her granddaughter for over six years while her parents visit her once a year. Hence, nurturing the grandchild had been her sole duty all those years and the role of parents nurturing their own children had been transferred on her shoulders. She did not complain when I asked her about the difficulties she faced while remaining in the household with the granddaughter alone, but she added

I am happy most of the time [for having good sons]. But sometimes, it can be tiring to look after the kid. Because there's been only me as an adult at home, I have to do household chores even when I don't feel well. And I also have to worry about the kid. (personal communication, April 23, 2014)

According to this, she did not think it was a burden to look after the grandchild while she did not need to worry about working for her living. Yet for a 63 year old woman, it could have been difficult sometimes to do household chores at the same time as taking care of the child all alone. As mentioned before, Daw Tuu was not the only one taking the role as a parent. Another parent of migrants whose children were left in the village talked about a similar situation. I interviewed U Mya who was in his late 60s. His eldest son left his two daughters with him and his wife. Just like Daw Tuu, the couple had been taking good care of those two children who were four and six years old at the time of the interview. He said

It is a bit tiring to look after the children. But we would have to struggle a lot if we just let them [his son and daughter-in-law] stay here. As grandparents, it is true that it's a little bit tiring to look after our grandchildren. But that's what we can do. (personal communication, April 26, 2014)

Essentially, this quote shows that he thought of being a caregiver for their grandchildren while their parents were away was for the sake of the family. It was tiring to some extent for the old couple, but they said it was not a big burden to take care of the grandchildren. 
The interviews with those participants evidently highlighted the role changes occurring within a family because of migration. In these families, the members working in Thailand had to give up the task as caregivers for their own children for economic reasons. As a consequence, these tasks had been transferred to their parents who remained at home. However, in this study, there is no evidence of a relationship between migration and health problems of non-migrant family members left at home.

In sum, this section has explained the changes with migrant households as a result of irregular migration. The changes identified in this study are transfer of traditional duties between husband and wife, and transfer of childcare duties to family members left behind. Evidently, these changes have crucial impacts especially on the wellbeing of family members left behind. My participants' responses indicate the burden of taking more responsibility that previously belonged to their members abroad at the time of interview, yet they willingly accepted those changes realizing it was for good sake of the family. This undeniably shows their perception in irregular migration as a family strategy confirming that NELM is applicable in irregular migration case.

\subsection{Social status in the community}

In addition to examining the impacts on left-behind members in migrant households, this study also investigated the change in their social status of households that have members working abroad. According to the New Economics of Labour Migration theory, migration decisions are made within the family and are influenced by wider social, political and cultural circumstances in the community (Stark, 1991; Stark \& Bloom, 1985). Thus, in order to get a better understanding of the social impacts of irregular migration, it is important to examine the status of migrant households in the community. One important finding about the social impacts of irregular migration in Nan Kham village is the change in the social status of households that have one or more migrants abroad. According to Massey (1990), international migration is a strategy for households to overcome relative deprivation ${ }^{46}$. Therefore, households try

\footnotetext{
${ }^{46}$ It is based on the theory of relative deprivation which explains that 'household well-being and satisfaction arise not only from improvements in absolute economic status but also
} 
not only to improve their earnings but also to improve their income relative to other households in the community (Massey, 1990). On the basis of this theory, my research also focused on the noticeable economic change of households after one or more members left to work in Thailand. This was achieved by exploring key factors that determine the social status of a family in the community and how families in the village try raising their household's image.

\subsubsection{Housing improvements as a promotion of social status}

The study finds housing improvements as means of promoting family status in the village, based on interviews with my participants and participant observation. As mentioned in the previous chapter, the responses of my participants indicated that remittances made it possible for them to build new concrete buildings and the houses of 13 of my participants were built by remittance money ${ }^{47}$. According to the village head, the majority of houses before 2000 were traditional-style houses which were made of thatch as roof and wood as walls. There were only two concrete buildings which were not built by remittances, hence all other buildings appeared after 2000, he added. To understand how this relates to the social status of the migrant households, it is also important to explore the social reasons for placing the construction of new house on the top of the list, other than for reasons such as improved safety, durability and weather tightness.

During my interview with $U$ Tin, the father of three migrant children working in Thailand, I asked him how sending his family members would affects people's views of his family. His answer is quoted below:

..People [in Nan Kham] might think that we have more income because our children are in Thailand. People used to look up to families that have members working abroad. It is the same for return migrants too. People think they bring back a lot of money... Some migrants can send money and some cannot, but when they do, their families build homes here [in the village].

through comparison with other households in the reference community' (Massey, 1990, p.13).

${ }^{47}$ The spending of remittances is explained in detail in Chapter V. 
For instance, my daughter has been sending 3-400,000 Kyats each year, so we saved that up and built this house. (personal communication, April 21, 2014)

He said households with migrants working abroad had a higher social status in the community because it was usually believed that they had more income and can build better houses. According to U San, people knew whether a family has a member working abroad by looking at their houses. He said:

... I think only about 30 per cent of the migrants cannot send money as they expected. If we look at the households with migrants abroad, most of them seemed to be all right [getting enough remittances]. If you look at the houses in the village, only 20 per cent of all the houses look like they have a financial struggle. (personal communication, April 22, 2014)

U San said that the majority of households were financially stable because of the migration to Thailand. It was noticeable that people would judge the economic status of the household by looking at the type of the house, according to him. People in Nan Kham called new concrete houses 'Yoe-da-yarr Tike', which in Myanmar language means 'Thai concrete-house' because they were built by remittances sent by migrants working in Thailand. U San was the first one to build the so-called Yoe-dayarr Tike, and he said other people in the village were inspired by him for having that building. This importance was noticeable when I talked to other respondents as well. For instance, when I asked Daw Yin about what other people would think about her son working abroad, she said

It really makes a difference sending a family member. [pointing at the neighbor's new concrete house] Just like that one, we used to have houses in a similar style. Yet after sending one family member, they could build a new concrete house (personal communication, April 23, 2014)

Basically, she thought that owning a new concrete house was the result of sending a family member abroad. Her neighbour could upgrade to a new house so she wanted 
to follow the same pathway. Most importantly, she was aware that her social status in the community depended on the type of house she lived in.

The previous studies also found that a large proportion of the remittances was used for housing improvements (McBride, 2009; Parrado, 2004) and migrant households in the sending areas had better housing conditions than households with no migrants (Kapur, 2005). Similarly, it was found that remittances were primarily used for housing improvements by my participants. In addition, it was proven that the improvement in housing is considered a key factor for promoting social status in Nan Kham village, according to my fieldwork. The interviews and participant observations, showed that remittances were primarily used for housing improvements, and it was believed that owning a new concrete house or 'Yoe-dayarr Tike' was a source of pride for many migrant households.

\subsubsection{Financial contribution in the village and religious affairs as a way to promote social status in the community}

Another noticeable finding from the data analysis is that financial contributions to village affairs and the organising of religious ceremonies are perceived as a way of promoting the household image in the community. As traditional Buddhist villagers, people of Nan Kham consider organizing traditional ceremonies, contributing donations to the monastery and village affairs as doing a good deed. According to my participants and participant observation, the most significant way that people would show their economic status is by organizing the monastic ordination ceremony called Shinbyu-pwe $e^{48}$. In Buddhist culture, it is believed that every boy has to be a young novice before they can beome adults. In order to ordain their sons into novicehood, parents usually organize Shinbyu-pwe. These events are essential for every Buddhist in Myanmar, and most of the time these events are costly to organize.

People are usually proud of how much they spend to organize such a ceremony, although it is not meant to be understood as competition in the community. According to U San, the cost of organizing a Shinbyu Pwe ranges from 5,000,000 to

\footnotetext{
${ }^{48}$ Shinbyu means ordination and Pwe means ceremony in Myanmar language.
} 
$10,000,000 \mathrm{Kyats}^{49}$ (approximately equal to USD 5,000 to USD 10,000) depending on the number of people invited. In Nan Kham village, Shinbyu Pwe is organized collectively every year, and parents who want their sons to be ordained in the ceremony share the costs. According to U San, the people working in Thailand come back each year just to participate and donate in Shinbyu Pwe. According to my participants, organizing this kind of event reflects the economic status of a household in Nan Kham.

Additionally, other interview responses indicated that the ability to make donations for village affairs and the village monastery is a result of their family members working abroad. The parents left behind at home told me that they could donate more than before. As a mother of two sons and one daughter currently working in Bangkok, one of my participants said:

I didn't have much before they went [to Thailand]. After they went, I could donate more. People see that they sent money to make donations as well... I mostly spend the money they send by donating. As you know, our Buddhist culture has many donation events such as Wah-so ${ }^{50}$, and Kyaung-tat-pwe ${ }^{51}$ (Daw Kyu, personal communication, April 24, 2014)

According to Daw Kyu, a substantial amount of the money she received goes to donations for religious events. Donations in Nan Kham village include offering food, necessities and robes to the monks, and contributions to the communal religious ceremony in the Myanmar New Year and on sacred days recognized by Myanmar Buddhism. She said she believed her donations would bring good luck both to her and her children who were abroad. As a Buddhist, it was her belief that equal benefit would return to her for something she gave away for a good purpose, and this belief

\footnotetext{
${ }^{49}$ This is an aggregate cost of the whole ceremony. Typically, one person hosts the event by contributing by a large proportion of the total cost. Other families which want their sons to be included share the rest.

${ }^{50}$ Wah-so (Myanmar term), also known as Vassa in Buddhist literature, is one of the sacred months in Myanmar calendar. Buddhists donate robes, foods and other materials to monk at this time of the year.

${ }^{51}$ This is a communal gathering of villagers in Nan Kham to visit different monasteries in order to pay homage to monks and make donations. Kyaung-tat-pwes were usually organized in April, June and October.
} 
is widely known as $\operatorname{Karma}^{52}$. She said the best way to use the money sent by her children for her particularly because she could still make her living by farm work and selling vegetables on the market. By donating to these traditional religious events, her status in the community was raised to some extent.

My interview participants seemed to agree that the increase of cash donations for religious affairs was a fruitful result of migration to Thailand. Another similar use for the remittances was as a donation for the improvements of the village's monastery. The head of the village agreed that there had been an increase in people's financial contributions to village and religious affairs. When I asked about the changes that he witnessed in the community with the majority of young people working in Thailand, he replied

The village has improved a lot now. They could support the village monastery with the money sent from abroad. For example, they have supported the building of a fence and the dining hall of the monastery. (U Min, personal communication, May 5, 2014)

According to him, the monastery building used to be made of wood. But now it had been upgraded to a concrete building and a new concrete fence had been erected. $\mathrm{He}$ said these renovations would not have been possible with the donations through incomes from agricultural products. Donations sent back by the migrants who were working in Thailand made it possible to upgrade the village monastery to a modern building. Apart from using the remittances to host religious events at home, donations to the monastery was also an act of honour for the villagers, according to my interviews and participant observation. As mentioned earlier, people in Nan Kham were proud of the donations they made because the amount of donation reflects their economic status.

In sum, this case highlights the relationship between the use of remittances in communal or religious donations and the promotion of social status in the

\footnotetext{
${ }^{52}$ Karma is one of the most basic doctrines of Buddha. Believing in Karma means believing that every actions have consequence and the actor will be beneficial or suffer according to his/ her action in the future.
} 
community according the data collected from Nan Kham. The most important implication here is that irregular migration in Lin Phine Gyi is seen as directly related to improving contributions in village and religious affairs. This was highlighted by exploring three main kinds of donation identified during my field work and how they are related to promoting a household's status in Nan Kham. Evidently, this contribution to village and religious events is a credit to migrant households abroad because they believe irregular migration provided a chance to contribute in those affairs. This entirely contradicts the traditional notion of irregular migration as 'illegal' or 'evil' as portrayed in the migration literature. Instead, it has been found that the remittances sent back from family members working abroad are vital for their contributions to hosting the religious events, making donation to those events and monastery's infrastructure improvements possible, when they were normally unaffordable for many villagers. This is not a unique case that the use of remittances is related to the status of migrant households in the local community. Faeamani (1995) finds that 'the annual church collection provides an opportunity to demonstrate one's economic and spiritual status to the whole community' (p. 145). He highlights that the migrant households contribute the highest amounts in those collections in Tonga. As traditional Buddhist villagers, people believe that everything they do will have a reflection, also known as Karma in Buddhist literature, and the act of donation is most commonly known as doing a good deed for the unforeseen future or next life. This essentially is the ultimate reason of making donations. When it comes to communal donations, people are proud of the amount of money they donate. This does not necessarily imply there is competition regarding religion status among villagers of Nan Kham, yet it is not deniable that more contributions of this kind make households proud of their acts.

\subsection{Conclusion}

This chapter discussed the significant findings on the social impact of irregular migration in Nan Kham village by analysing role changes within households and the impact on social status in the community. It discussed the role changes and transfer of duties in remaining households resulting from the migration of family members. The findings here highlight that taking the responsibility for the absent members was 
burdensome for family members remaining in the area of origin. In addition, it also highlighted the importance of housing improvements and contributions to communal affairs as an attempt for migrant households to promote their status in the community. Based on the findings in this study, it is confirmed that NELM is also applicable for irregular migration where sending family members through irregular channel is considered a family strategy. It is noticeable that remaining household members delightfully bear the duties previously belong to their members working abroad at the time of the study. Most importantly, it was also found that locals do not perceive irregular migration as evil or an illegal type of livelihood, but as a way to improve household income to be able to have good reputation in the community through making donations and pursuing a higher living standard. 


\section{CHAPTER VII: CONCLUSION}

\subsection{Summary of findings and its inferences}

The main conclusion of this thesis is that processes of irregular migration resemble those of regular migration more than the myths around 'human smuggling' would suggest. According to this study, irregular migration produces not only negative but also distinctly positive impacts on families left behind, similar to that of conventional labour migration through regular channels. Three main findings support this conclusion. These are based on how human smuggling operates in local context, how it impacts on economic aspects of families left behind and how it impacts on social aspects of families left behind.

First, contrary to the conventional assumption that human smuggling is managed by large criminal organizations, I found that people in Nan Kham village use personal friends and relatives as helpers to smuggle themselves across the border. According to the findings from the study, these smuggling operations are based on the personal contacts and evidently there is always an existing relationship between smugglers and the migrants prior to the migration to Thailand. This study also found that the smugglers are often just individuals trying to meet their ends by transporting migrants across the border using their experiences and contacts, and not criminal organizations or members of networks. And crucially, human smuggling is not even perceived as "irregular" in this context: instead it is understood as a normal way to promote their household's income and living standards.

I found that the smuggling in Nan Kham village is often even simpler and more disorganized than just described. In many cases, the migrants smuggle themselves without assistance from any intermediaries. My participants could choose different ways to smuggle themselves across the border without any bond or contracts. Different ways identified in this study include travelling by car or motorbike. Unavoidably, these smuggled migrants need to anticipate the risk of crossing the border illegally. My participants could just walk or go on motorbike across the 
border. If caught, they could be detained for about three days and sent back to the border. One of my participants who had had this experience said "He called the same smuggler to send him again". These situations do not entail danger for my participants and I did not have any evidence of physical abuse from my participants.

Secondly, instead of the notion that the smuggling leads to debt and economic burdens to the family, I found that human smuggling from Nan Kham does not incur any long-term debt or create a particularly harsh burden on families left behind. Human smuggling fees are indeed expensive for families in Nan Kham village, yet they are still cheaper than the cost of regular migration. In this case study, the human smuggling fees were paid through savings, selling jewellery or getting loans from neighbours while realizing that sending migrants to Thailand is an investment for the whole household. It was also found that the existing migrant networks are vital in reducing the migration related expenses. The example cases include migrant siblings paying the travel cost and friends assisting the new migrants by providing shelter and finding jobs. In this way, my participants' households could avoid owing a substantial amount of debt to human smugglers or local moneylenders. The households of my participants could increase income and consumption that are vital in raising their standard of living. Further evidence shows that families were able to save and invest as a result of human smuggling, and build new houses which would otherwise be impossible.

Additionally, far from creating a burden, the remittances resulting from human smuggling substantially improve the incomes of my participants' households. The study did not collect the detail expenditures of the remittances, yet, the priority expenses spent through remittances were identified by the participants were housing improvements, making donations and day-to-day consumption. A large proportion of remittances were spent on building the new house, therefore, this implies the creation of construction-related jobs in and around the village. There was no indication of direct impacts from donation and household consumption on the community. However, it is believed that the income improvement of migrant households has profound impacts on local market economy (Taylor, 1999). Thus, as a small village, it appears that the increase of income and consumption of migrant households will 
benefit local businesses, particularly small stores and businesses in and around Nan Kham.

Third, as this study hypothesizes, the evidence from Nan Kham show that the social and economic impacts of irregular migration are similar to the impacts on families left behind found by NELM scholars. In economic means, it is found that remittances create uneven investment opportunities among migrants. It is noticeable that only the earlier group of migrants has got the opportunity to invest, whereas latter group of migrants just continue working in Thailand because of the lack of opportunities to invest. The types of investment identified in this case study are investments in trendy or short-term fashionable businesses, setting up mini-stores and trading seasonal crops. Nevertheless, for a small village with only under 100 households, Nan Kham does not seem to have many attractive investment opportunities for most of the migrant households. The case study has illustrated successful stories of return migrants, yet those opportunities only seemed to be feasible for the ones who migrate and return earlier. These two economic impacts have substantial influence on social impacts on the families left behind discussed in Chapter VI.

In terms of social impacts, the study found that irregular migration is an influential factor in changing roles within the family and promoting the social status in the community. It is also found that these impacts create a further burden on family members left behind in taking on more responsibilities and growing inequality in the village. Firstly, irregular migration has a considerable influence in changing roles in migrant households. The study identified changing roles in the cases of male migration, female migration and parental migration specific to individual migrant households in the study. In case of female migration and male migration, the traditional duties were transferred to the partner left behind. This situation impacts on the status and wellbeing of those left behind partners. For instance, left behind husbands become responsible for both farm work and childcare work in which the former one is his original responsibility and latter task was usually understood as 'women's work'. Likewise, in addition to their conventional duties of doing household chores and childcare, left behind women have to undertake farm work and representation in the village's affairs. These extra responsibilities seemed to burden the partner left behind, yet my participants are likely to accept them in exchange for 
the improvement of their living standard and wealth. At the community level, it was also found that locals do not perceive irregular migration as evil or illegal type of livelihood, but as a way to improve their household income and be able to have a good reputation in the community through making donations and pursuing a higher living standard.

In sum, departing from the traditional notion that describes irregular migration as 'illegal' and 'evil', these conclusions confirm that the impacts as a result of irregular migration are similar to the impacts of international migration as described by NELM in many aspects. Therefore, it can be concluded that irregular migration in Nan Kham village entails the impacts similar to those created by international migration, although the process in which migration occurs is different.

\subsection{Contributions}

This study has shown that there are developmental implications by providing an alternative perspective about irregular migration from Myanmar to Thailand. Previous studies about irregular migration from Myanmar have been focused on the situation of Myanmar migrant workers in Thailand. Departing from the notion that irregular migration is an unpleasant phenomenon, this study highlights how migrant households in the area of origin perceive the irregular migration process. The study also highlights the importance of migrant families left behind in a rural village in Myanmar and their influence to the wider community through the spending of remittances. As irregular migration evidently has many impacts for the development of rural areas, this study addresses one of the most important issues for the development of a growing country like Myanmar. Even more importantly, this study has relevance beyond Myanmar for many others countries involved in similar processes.

On the academic side, this thesis sought to contribute to the literature on irregular migration and the migration industry. Its emphasis on irregular migration's process and impacts in reference to the New Economics of Labour Migration is a unique approach within migration literatures. Previously, less attention has been placed on 
the impacts of migration and its implications on remaining families in the sending area in the case of irregular migration. This study brings those different sets of literature together and made a justifiable contribution through a case study of irregular migration from Myanmar to Thailand. Thus, this study has contributed to the wider literature on migration by investigating the process and impacts of irregular migration on remaining families through NELM lens.

\subsection{Limitations of the study}

The study entails both personal and methodological limitations. As a novice researcher, my ability to articulate the best research design and applying methodologies can also be regarded as a limitation. However, I addressed this limitation by being flexible with research design and adjusting research question guide during my fieldwork. I was also aware that my personal bias as an insider researcher has impacts on the outcomes of the research project. To resolve this, I took precaution on the data collection, data analysis and writing-up stages.

In terms of methodological limitation, the study involves constraints in sampling and recruitment. Being a qualitative study, the study covers a few population and places within the study topic, as suggested by Descombe (2007). Moreover, during the participant recruitment process, I could not include some of the potential participants who were busy or too shy to talk. The study is based on 16 participants who have experience with human smuggling process and impacts, therefore, I am aware that this reports only tells 'part' of the bigger story about irregular migration. Anticipation of this leads to my suggestions on future research directions. 


\subsection{Future research directions}

This study has found that irregular migration has profound developmental implications on the families left behind in sending areas. Based on the findings in this study, two suggestions can be made for future research direction.

Firstly, more research on how human smuggling is run in border areas should be carried out. This research project highlights the importance of different actors facilitating the human smuggling operations in particular reference to the assistance of friends, relatives and siblings. As the research indicates, these operations will not be accomplished without brokers or agents who reside near the border helping the migrants by providing different ways to cross the Thai-Myanmar border. With the time and contacts available at the time of data collection, the study could not explore how these brokers and agents perceive their business and how these human smuggling operations work at the border area. Therefore, in order to understand the best about the nature of human smuggling operations, the future effort should be put in learning about human smuggling operations in transiting areas such as border towns or villages on both sides of the countries where irregular migration occurs.

Secondly, future research should also be directed towards studying about the influence of rural out-migration on the young people's motivation for education in the same area. One of the findings from this study indicates that young people in the village has less interest to study because they realize they could go abroad even without having any qualifications. The critical concern here is that there might not be educated people working in different sectors for the development of the village as a result of relying entirely on the export of low-skilled labour to Thailand. Therefore, it calls for a need to study about how and to what extent the irregular migration impacts on the young people's motivation in education in migrant sending areas. 


\section{REFERENCES}

Adams, R. H. (1991a). The economic uses and impact of international remittances in rural Egypt. Economic Development and Cultural Change, 39 (4), 695-722.

Adams, R. H. (1991b). The effects of international remittances on poverty, inequality and development in rural Egypt. Washington, D.C.: International Food Research Policy Institute.

Antman, F. M. (2012a). The impact of migration on family left behind. Bonn: University of Colorado at Boulder and IZA, Department of Economics. IZA Discussion Paper No. 6374.

Antman, F. M. (2012b). Gender, education attainment, and the impact of parental migration to children left behind. Journal of Population Economics, 25, 1187- 1214.

Arnold, D. \& Pickles, J. (2011). Global work, surplus labor, and the precarious economies of the border. Antipode, 43 (5), 1598- 1624.

Asis, M. M. B., Huang, S., \& Yeoh, B. S. A. (2004). When the light of the home is abroad: Unskilled female migration and the Filipino family. Singapore Journal of Tropical Geography, 25 (2), 198-215.

Bastistella, G., \& Conaco, M, C, G. (1996). Impact of migration on the children left behind. Asian Migrant, 9(3), 86-91.

Bazeley, P. (2013). Qualitative data analysis: Practical strategies. London: SAGE Publication Ltd.

Bilger, V., Hofmann, M., and Jandl, M. (2006). Human smuggling as a transnational service industry: Evidence from Austria. International Migration, 44 (4), 59 93.

Boyd, M., \& Grieco, E. (2003). Women and migration: incorporating gender into international migration theory. Migration Information Source, 1. Retrieved on 1 Dec 2014 from /http://incedes.org.gt/Master/boydgriecodiez.pdf/

Boyle, P., Graham, E., \& Yeoh, B. (2003). Editiorial introduction: Labour migration and the family in Asia. International Journal of Population Geography, 9, 437-441. 
Burke, C. (2008). Smuggling versus trafficking: Do the U.N. Protocols have it right? Human Rights and Human Welfare. Josef School of International Studies: University of Denver.

Burnard, P. (1991). A method of analysing interview transcripts in qualitative research. Nurse Education Today, 11, 461- 466.

Caoutte, T. M., \& Pack, M. E. (2002). Pushing past the definitions: Migration from Burma to Thailand. Refugee International and Open Society Institute: Bangkok.

Carling, J., Erdal, M. B., \& Ezzati, R. (2014). Beyond the insider-outsider divide in migration research. Migration Studies, 2 (1), 36-54.

Carter, S. M., \& Little, M. (2007). Justifying knowledge, justifying method, taking action: Epistemologies, methodologies and methods in qualitative research. Qualitative Health Research, 14 (10), 1316- 1328.

Castles, S. \& Miller, M. J. (2003). The Age of Migration ( $3^{\text {rd }}$ Edition). Guildford Press: New York.

Chacko, E. (2004). Positionality and praxis: Fieldwork experience in rural India. Singapore Journal of Tropical Geography, 25 (1), 51- 63.

Chantavanich, S \& Vungsiriphisal, P. (2012). Myanmar migrants to Thailand and implications to Myanmar development. Bangkok Research Center. Policy Review Series on Myanmar Economy No. 7.

Creswell, J. W. (2003). Research Design: Qualitative, quantitative and mixed methods approaches ( $2^{\text {nd }}$ Edition). London: SAGE Publications Ltd.

Davidson, J. O. (2003). Troubling freedom: Migration, debt, and modern slavery. Migration Studies, 1 (2), 176- 195.

De Haas, H. (2010), Migration and development: A theoretical perspective. International Migration Review, 44, 227-264.

Durand, J., \& Massey, D. S. (1992). Mexican migration to the United States: A critical review. Latin American Research Review, 27(2), 3-42.

De Haas, H. (2005). International migration, remittances and development: Myths and facts. Third World Quarterly, 26(8), 1269-1284.

Descombe, M. (2007). The Good Research Guide for small-scale social research projects ( $3^{\text {rd }}$ Edition). England: Open University Press.

Faeamani, S. 'U. (1995). The impacts of remittances on rural development in Tongan villages. Asia and Pacific Migration Journal, 4 (1), 139- 155. 
Friebel, G., and Guriev, S. (2006). Smuggling humans: A theory of debt-financed migration. Journal of the European Economic Association, 4(6), 1085-111.

Funder, M. (2005). Bias, intimacy and power in qualitative fieldwork studies. The Journal of Transdisciplinary Environmental Studies, 4 (1), 1-9.

Giannelli, G. C., and Mangiavacchi, L. (2010). Children's schooling and parental migration: Empirical evidence on the 'left-behind' generation in Albania. LABOUR, 24, 76-92.

Gibson, J., McKenzie, D., \& Stillman, S. (2011). The impacts of international migration on remaining household members: Omnibus results from a migration lottery program. Review of Economics and Statistics, 93(4), 12971318.

Guo, M., Aranda, M. M. \& Silverstein, M. (2009). The impact of out-migration on the inter-generational support and psychological wellbeing of older adults in rural China. Ageing and Society, 29, 1085-1104.

Hall, A. (2012). Myanmar and migrant workers: Briefing and recommendations. Bangkok: Mahidol Migration Center.

Hugo, G. (2002). Effects of international migration on families in Indonesia. Asia and Pacific Migration Journal, 11 (1), 13-46.

Hugo, G., \& Ukwatta. (2010). Sri Lanka domestic workers overseas - The impact on their children. Asia and Pacific Migration Journal, 19 (2), 237-263.

Içduygu, A. (2004). Transborder crime between Turkey and Greece: Human smuggling and its regional consequences. Southeast European and Black Sea Studies, 4(2), 294-314.

Içdyugu, A., \& Toktas, S. (2002). How do smuggling and trafficking operate via irregular border crossings in the Middle East? Evidence from fieldwork in Turkey. International Migration, 40 (6), 25- 54.

International Organization for Migration. (2000). Migrant trafficking and human smuggling in Europe. Geneva: IOM.

Jones, R. C. (2014). Migration and family happiness in Bolivia: Does social disintegration negate economic well-being? International Migration, 52 (3), 177-193.

Kapur, D. (2004). Remittances: The new development mantra? United Nations: New York \& Geneva. G-24 Discussion Paper no. 29. 
Kayah State Socio-Economic Analysis. (2013). In Mercycorps [Webpage]. Retrieved on 29 August 2014 from /http://www.mercycorps.org/ researchresources/socio-economic-analysis-kayah-state-myanmar/

King, R., \& Vullnetari, J. (2006). Orphan pensioners and migrating grandparents: The impact of mass migration on older people in rural Albania. Ageing and Society, 26(5), 783-816.

Koc, I., and Onan, I. (2004). International migrants' remittances and welfare status of the left-behind families in Turkey. International Migration Review, 38 (1), 78-112.

Koser, K. (2008). Why migrant smuggling pays. International Migration, 46(2), 3 27.

Koser, K. (2010). Dimensions and dynamics of irregular migration. Population, Space \& Place, 16, 181-193.

Kyle, D. \& Liang, Z. (2001). Migration merchants: Human smuggling from Ecuador and China. Center for Comparative Immigration Studies. UC San Diego: Center for Comparative Immigration Studies. Retrieved from: /https://escholarship.org/uc/item/5h24b7j6/

Lindquist, J. (2012). The Elementary School Teacher, the Thug and his Grandmother: Informal Brokers and Transnational Migration from Indonesia. Pacific Afairs, 85 (1), 69-89.

Lindquist, J., Xiang, B. \& Yeoh, B. (2012). Opening the Black Box of Migration: Brokers, Organization of Transnational Mobility and the Changing Political Economy in Asia. Pacific Affairs, 85 (1), 7-19.

Leimpt, I. v., \& Doomernik, J. (2006). Migrant's agency in the smuggling process: The perspectives of smuggled migrants in the Netherlands. International Migration, 4 (4), 165-190.

Leimpt, I. v. (2007). Navigating Borders: An Inside Perspective into the Process of Human Smuggling. Amsterdam: Amsterdam University Press.

Marshall, C. \& Rossman, G. B. (2006). Designing qualitative research [4 ${ }^{\text {th }}$ Edition]. London: SAGE Publication Ltd.

Massey, D. S. \& Parrado, E. (1994). Migradollars: The remittances and savings of Mexican migrants to the United States. Population Research and Policy Review, 13, 3- 30. 
Massey, D. S., Arango, J., Hugo, G., Kauaouci, A., Pellegrino, A., \& Taylor, J. E. (1993). Theories of international migration: A review and appraisal, Population and Development Review, 19 (3), 431-466.

Matejskova, T. (2014). Deep situationality: Interstitial spaces and limits of identity in ethnographies of politics of immigrant integration. Migration Studies, 2 (1), $16-35$.

McBride, B., \& Fransen, J. (2009). Building capital: The role of migrant remittances in housing improvement and construction in El Salvador. Inter-American Development Bank. Retrieved on 1 Dec 2014 on /http://www.microfinancegateway.org/library/building-capital-role-migrantremittances-housing-improvement-and-construction-el-salvador/

McGann, N. (2013). The openings of Burmese borders: Impacts on migration. Migration Policy Institute [webpage]. Accessed on 4 Oct 2014 from / http://www.migrationpolicy.org/article/opening-burmese-borders-impactsmigration/

McKeown, A. (2012). How the Box Became Black: Brokers and the Creation of the Free Migrant. Pacific Affairs, 85 (1), 21-45.

Molland, S. (2010). 'The perfect business': Human Trafficking and Laos-Thai CrossBorder Migration. Development and Change, 41 (5), 831-855.

Molland, S. (2012). Safe Migration, Dilettante Brokers and the Appropriation of Legality: Laos-Thai "Trafficking" in the Context of Regulating Labour Migration. Pacific Affairs, 85 (1), 117-136.

Morgan, D. (2008). Snowball sampling. In L. Given (Ed.), The SAGE encyclopedia of qualitative research methods. (pp. 816-817). Thousand Oaks, CA: SAGE.

Morse, J. 2000. Determining sample size. Qualitative Health Research, 10, 3-5.

$\mathrm{Mu}, \mathrm{R} .$, \& van de Walle, D. (2011). Left behind to farm? Women's labor reallocation in rural China, Labour Economics, 18 (1), 83-97.

Nagar, R. \& Susan, G. 2007. Reflexivity and positionality in feminist fieldwork revisited. In T. Adam, E. Sheppard, J. Peck and T. Barnes (Eds), Politics and Practice in Economic Geography (267-278). London: SAGE.

Nowicka, M. \& Cieslik, A. (2014). Beyond methodological nationalism in insider research with migrants. Migration Studies, 2 (1), 1 - 15. 
Osili, U. O. (2007). Remittances and savings from international migration: Theory and evidence using a matched sample. Journal of Development Economics, $83,446-465$.

Pantea, M. C. (2012). Grandmothers as main caregivers in the context of parental migration. European Journal of Social Work, 15 (1), 63- 80.

Pastore, F., Monzini, P., \& Sciortino, G. (2006). Schengen's soft underbelly? Irregular migration and human smuggling across land and sea borders to Italy. International Migration, 44 (4), 95-119.

Parrado, E. A. (2004). Migration, home ownership, and housing quality in Mexico. In J. Durand and D. S. Massey (Eds.). Behind the Smoke and Mirrors: Research from the Mexican Migration Project. New York: Russell Sage Foundation.

Piracha, M., Randazzo, T., \& Vadean, F. (2013). Remittances and occupational outcomes of the household members left-behind. Bonn: University of Colorado at Boulder and IZA, Department of Economics. IZA Discussion Paper No. 7582.

Raihan, S., Khondker, B. H., Sugiyarto, G., \& Jha, S. (2009). Remittances and household welfare: A case study of Bangladesh. Philippines: Asian Development Bank. ADB Economics Working Paper Series No. 189.

Salt, J. (2000). Trafficking and human smuggling: A European perspective. International Migration, 38 (3), 31-56.

Sandelowski, M. (1995). Focus on qualitative methods: Sample size in qualitative research. Research in Nursing and Health, 18, 179-183.

Set Aung, W. (2009). Illegal heroes and victimless crimes: Informal cross-border migration from Myanmar. Stockholm: Institute for Security and Development Policy.

Skeldon, R. (2002). Migration and poverty. Asia-Pacific Population Journal, 17 (4), 67-82.

Stahl, C. W. \& Arnold, F. (1986). Oversea workers' remittances and Asian development. International Migration Review, 20(4), 899-925.

Stark, O., \& Bloom, D. E. (1985). The New Economics of Labour Migration. The American Economic Review, 75 (2), 173-178.

Stark, O. (1991). The migration of labour. UK: Basil Blackwell. 
Stoll, D. (2010). From wage migration to debt migration? Easy credit, failure in El Norte, and foreclosure in a bubble economy of the Western Guatemalan Highlands. Latin American Perspectives, 37 (1), 123- 142.

Tamura, Y. (2010). Migrant smuggling. Journal of Public Economics, 94, 540-548. Taylor, J. E. (1992). Remittances and inequality reconsidered: Direct, indirect, and intertemporal effects. Journal of Policy Modeling, 14(2), 187-208.

Taylor, J. E., Argongo, J., Hugo, G., Kouaouci, A., Massey, D. S. \& Pelligrino, A. (1996). International migration and national development. Population Index, 62(2), 181-212.

Taylor, J. E. (1999). The new economics of labour migration and the role of remittance in the migration process. International Migration, 37 (1), 63-88.

Taylor, J. E., Rozelle, S., \& De Brauw, A. (2003). Migration and incomes in source communities: A new economics of migration perspective from China. Economic Development and Cultural Change, 52(1), 75-101.

Taylor, J. E., Mora, J., Adams, R., \& Lopez-Feldman, A. (2005). Remittances, inequality and poverty: Evidence from rural Mexico. Department of Agricultural \& Resource Economics: University of California.

Thomson, S. B. (2011). Sample size and grounded theory. Journal of Administration and Governance, 5 (1), 45- 52.

Turnell, S., Vicary, A. \& Bradford, W. (2008). Migrant worker remittances and Burma: An economic analysis of survey results. Burma Economic Watch: Australia.

United Nations. (2000a). Protocol to prevent, supress and punish trafficking in persons, especially women and children, supplementing the United Nations convention against transnational organized crimes. Geneva: United Nations.

United Nations. (2000b). Protocol against smuggling of migrants by land, sea and air, supplementing the United Nations convention against transnational organized crimes. Geneva: United Nations.

United Nations Office on Drugs and Crime. (2011). Smuggling of migrants: A global review and annotated bibilography of recent publications. New York: United Nations.

United Nations High Commissioner for Refugees. (2014). Kayah State Myanmar. UNHCR South-east Myanmar Data Management Unit. Retrieved on 29 August 2014 from /http://data.unhcr.org/thailand/search.php/ 
Unluer, S. (2012). Being an insider researcher while conducting case study research. The Qualitative Report, 17 (58), 1- 14.

Wood, C. H. (1982). Equilibrium and historical-structural perspectives on migration. International Migration Review, 16 (2), 298-319.

Yabiku, S, T., Agadjanian, V. \& Sevoyan, A. (2010). Population Studies, 64 (3), 293- 306.

Yin, R. K. (1994). Case study research: Design and methods [2 ${ }^{\text {nd }}$ Edition]. London: SAGE Publication Ltd.

Zlotnik, H. (1995). Migration and the family: A female perspective. Asia and Pacific Migration Journal, 4 (2-3), 253-271.

Zhou, M., Murphy, R., and Tao, R. (2014). Effects of parents' migration on the education of children left behind in rural China. Population and Development Review, 40(2), 273-292. 


\section{APPENDIX I: Summary of Participants}

\begin{tabular}{|c|c|c|c|c|c|c|c|c|c|c|c|c|c|}
\hline \multirow{2}{*}{ No. } & \multirow{2}{*}{$\begin{array}{c}\text { Name } \\
\text { (pseudonyms) }\end{array}$} & \multirow{2}{*}{ Age } & \multirow{2}{*}{ Ethnicity } & \multirow{2}{*}{$\begin{array}{l}\text { Other income } \\
\text { sources }\end{array}$} & \multirow{2}{*}{ Person assisted to go abroad } & \multicolumn{6}{|c|}{ No. of migrant abroad } & \multirow{2}{*}{$\begin{array}{l}\text { No. of } \\
\text { return } \\
\text { migrant }\end{array}$} & \multirow{2}{*}{$\begin{array}{c}\text { No. of } \\
\text { family } \\
\text { members }\end{array}$} \\
\hline & & & & & & ণ & 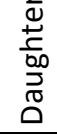 & $\begin{array}{l}\frac{n}{2} \\
\frac{\pi}{2} \\
\frac{\pi}{2}\end{array}$ & 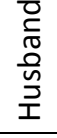 & $\stackrel{\stackrel{\oplus}{*}}{3}$ & $\frac{\infty 0}{.0}$ & & \\
\hline 1 & U Tin & 54 & Shan & Farming ( 2 acres) & A broker from another village & 2 & 1 & & & & & & 6 \\
\hline 2 & U San & 40 & Shan & Rice mill & Relatives & & & & & & & 2 & 7 \\
\hline 3 & Daw Yin & 43 & Shan & Farming & Relatives & 1 & & & 1 & & & & 3 \\
\hline 4 & Daw Tuu & 63 & Shan & Farming ( 3 acres) & Friends & 4 & & & & & & & 6 \\
\hline 5 & U Kyaw & 72 & Shan & Farming & Relatives & & 2 & & & & & & 5 \\
\hline 6 & Daw Kyu & 58 & Shan & Farming & Relatives & 2 & 1 & & & & & & 4 \\
\hline 7 & U Mya & 68 & Shan & Farming ( 2 acres) & Relatives & 2 & 1 & & & & & & 7 \\
\hline 8 & U Aung & 33 & Shan & Farming & Friends & 1 & 1 & & & & & 1 & 5 \\
\hline 9 & U Min & 48 & Shan & Farming (7 acres) & $\mathrm{N} / \mathrm{A}$ & & & & & & & & 2 \\
\hline 10 & U Toe & 61 & Shan & Farming (5 acres) & Friends & & 1 & & & & & & 4 \\
\hline 11 & U Kan & 41 & Shan & Farming (5 acres) & Relatives & & 1 & & & 1 & & 1 & 3 \\
\hline 12 & $\mathrm{UNu}$ & 29 & Shan & Farming (3.5 acres) & $\mathrm{N} / \mathrm{A}$ & & & & & & & & 4 \\
\hline 13 & Daw Hla & 32 & Shan & Mini store & Friends & & & & & & 3 & 1 & 8 \\
\hline 14 & Daw Shwe & 25 & Shan & Ministore & Neighbour/relative & & & & & & & 2 & 3 \\
\hline 15 & U Myo & 35 & Shan & Farming & Friends & 1 & 1 & & & & & 1 & 5 \\
\hline 16 & Daw Ei & 29 & Inn & N/A & N/A & & & & & & & & \\
\hline
\end{tabular}




\begin{tabular}{|c|c|c|c|c|c|c|c|c|}
\hline \multirow[b]{2}{*}{ No. } & \multirow[b]{2}{*}{ Name* } & \multirow{2}{*}{$\begin{array}{l}\text { Expense/ } \\
\text { brokering } \\
\text { fee (Kyats) }\end{array}$} & \multirow[b]{2}{*}{ Way of paying the fee } & \multirow{2}{*}{$\begin{array}{l}\text { Estimated } \\
\text { annual } \\
\text { remittances } \\
\text { (Kyats) }\end{array}$} & \multirow{2}{*}{$\begin{array}{l}\text { Interview's } \\
\text { status in } \\
\text { relation to the } \\
\text { migrant }\end{array}$} & \multirow{2}{*}{$\begin{array}{l}\text { Way of } \\
\text { sending } \\
\text { money }\end{array}$} & \multicolumn{2}{|r|}{ Remark } \\
\hline & & & & & & & $\begin{array}{l}\text { Date of } \\
\text { interview }\end{array}$ & Category \\
\hline 1 & U Tin & & One-time payment & & Father & Hundi & 21.4.14 & $\begin{array}{l}\text { Village leader/ Family with children } \\
\text { abroad }\end{array}$ \\
\hline 2 & U San & $\begin{array}{l}20000 \\
(1995) \\
\end{array}$ & One-time payment & & Self & & 22.4 .14 & Ex-transporter/ Return migrant couple \\
\hline 3 & Daw Yin & 400000 & Loan & & Wife/Mother & & 23.4 .14 & Husband abroad \\
\hline 4 & Daw Tuu & 200000 & One-time payment & $1,200,000$ & Mother & Hundi & 23.4.14 & Family with children abroad \\
\hline 5 & U Kyaw & 200000 & One-time payment & $2,400,000$ & Father & Bank & 24.4 .14 & $\begin{array}{l}\text { Village's elders/ Family with children } \\
\text { abroad }\end{array}$ \\
\hline 6 & Daw Kyu & 250000 & One-time payment & 200,000 & Mother & Hundi & 26.4 .14 & Family with children abroad \\
\hline 7 & U Mya & 200000 & One-time payment & $1,200,000$ & Father & Hundi & 26.4 .14 & Family with children abroad \\
\hline 8 & U Aung & 200000 & One-time payment & $2,400,000$ & Self/husband & Bank & 26.4.14 & $\begin{array}{l}\text { Wife abroad(return migrant with wife } \\
\text { abroad) }\end{array}$ \\
\hline 9 & U Min & & & & & & 5.5 .14 & Village's head/Family with no migrants \\
\hline 10 & U Toe & 200000 & One-time payment & $1,000,000$ & Father & Bank & 9.5 .14 & Family with children abroad \\
\hline 11 & U Kan & 400000 & One-time payment & $2,400,000$ & Self/husband & Hundi & 9.5 .14 & Wife abroad \\
\hline 12 & $\mathrm{UNu}$ & & One-time payment & & $\mathrm{N} / \mathrm{A}$ & & 23.4.14 & Family with no migrants \\
\hline 13 & Daw Hla & & One-time payment & & Self & Hundi & 10.6.14 & Return migrant \\
\hline 14 & $\begin{array}{l}\text { Daw } \\
\text { Shwe }\end{array}$ & & One-time payment & & Self & Hundi & 10.6.14 & Return migrant \\
\hline 15 & U Myo & & One-time payment & & Self & Hundi & 11.6.14 & Return migrant \\
\hline 16 & Daw Ei & & & & $\mathrm{N} / \mathrm{A}$ & & 22.6.2014 & Headmistress \\
\hline
\end{tabular}




\section{APPENDIX II: Ethics Approval}

MEMORANDUM

Phone $\quad 0-4-4635676$

Fax 0-4-4635209

Email Allison.kirkman@vuw.ac.nz

\begin{tabular}{|c|c|}
\hline TO & Ko Ko Si Thu \\
\hline COPY TO & Alan Gamlen \\
\hline FROM & Dr Allison Kirkman, Convener, Human Ethics Committee \\
\hline DATE & 27 March 2014 \\
\hline PAGES & 1 \\
\hline SUBJECT & $\begin{array}{l}\text { Ethics Approval: } 20662 \\
\text { Social and Economic Effects of Irregular Migration on Families of } \\
\text { Migrants in Myanmar }\end{array}$ \\
\hline
\end{tabular}

Thank you for your application for ethical approval, which has now been considered by the Standing Committee of the Human Ethics Committee.

Your application has been approved from the above date and this approval continues until 28 February 2015. If your data collection is not completed by this date you should apply to the Human Ethics Committee for an extension to this approval.

Best wishes with the research.

Allison Kirkman

Human Ethics Committee

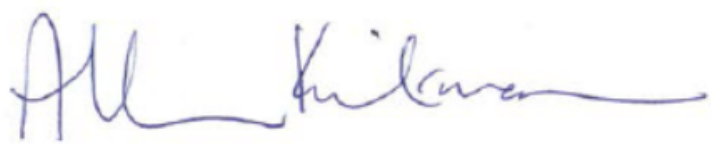




\section{APPENDIX III: Interview Guide}

\section{Questions used:}

Tell me about how and why your family member went abroad.

1). How does irregular migration change the internal structure and social status of families in migrants' area of origin?

\section{Sub-questions}

- Do you see any changes in your family in terms of household management and decision-making in family affairs?

- Do you see any of those changes in other families which also have their members working abroad?

- What do you think about these changes?

- How does having a family member working abroad change people's views of your family's status?

- What do you think about the status of families which have their members working abroad?

2). How do households use remittances sent by family members?

Sub-questions

- Who spends the remittances in your family and what do they spend them on?

- Why do you spend this way? 


\section{APPENDIX IV: Questionnaires (Burmese)}

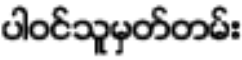

\begin{tabular}{|l|l|}
\hline 6\$९ - & ฤळळ్ - \\
\hline
\end{tabular}

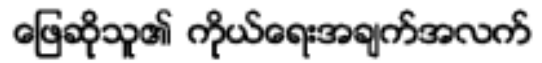

ग зә๗र्ट

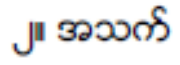

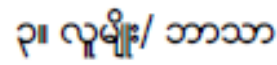

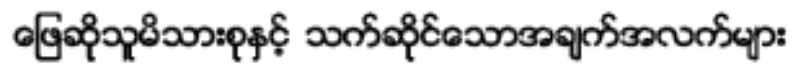

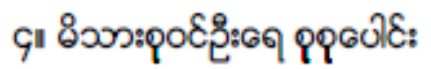

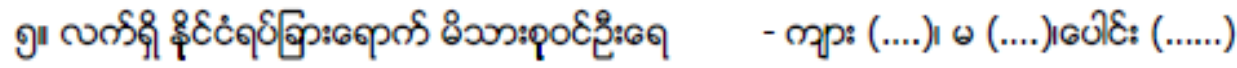

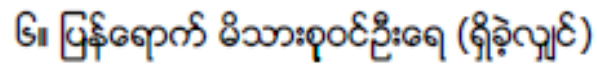

ని:

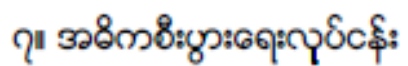

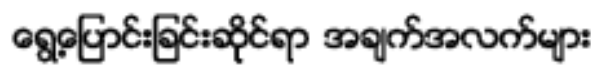

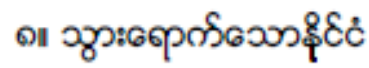

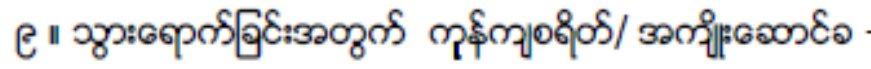

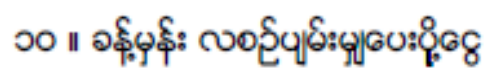

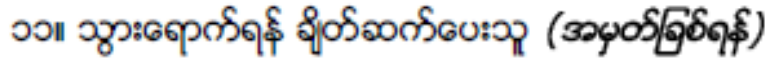

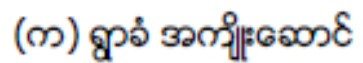

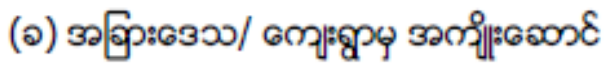
(๑) เฉเి|:
(బ) $325:$

৩

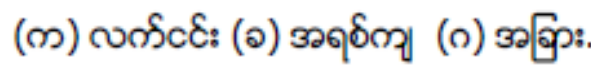

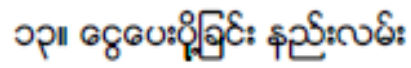

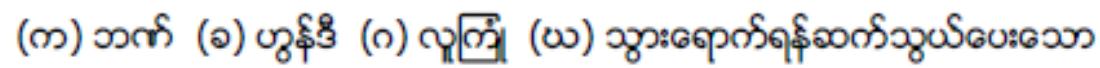

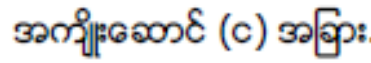

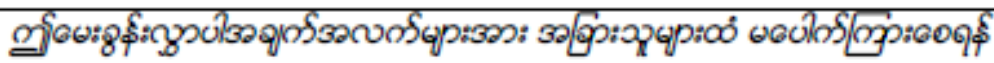

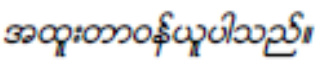




\section{APPENDIX V: Information for participants (Burmese)}

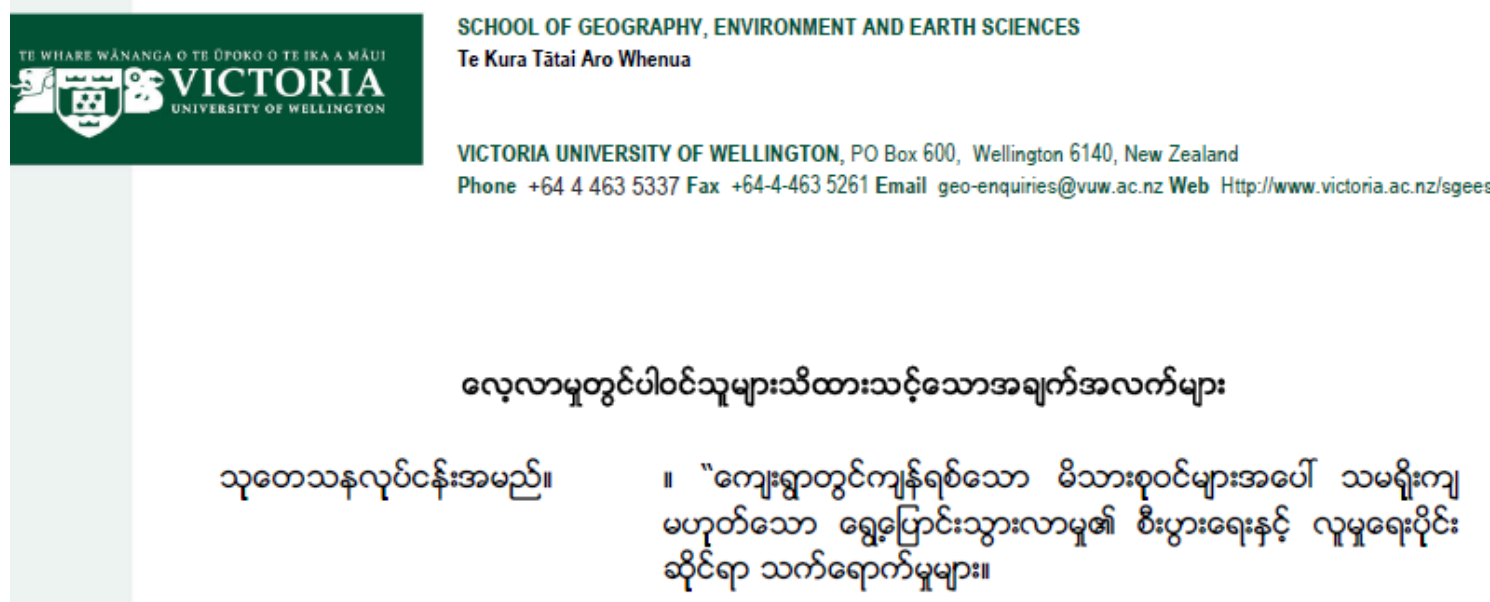

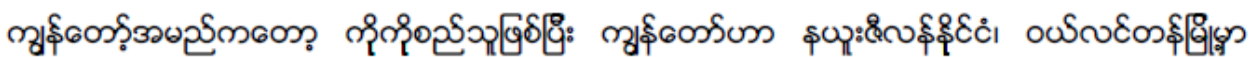

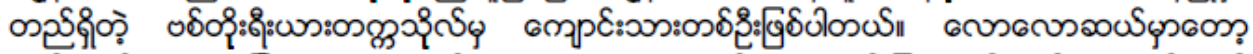

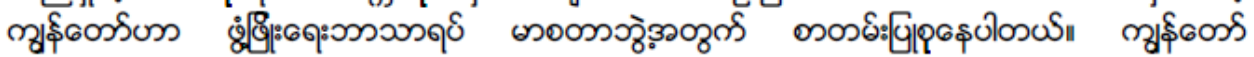

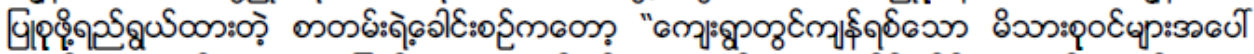

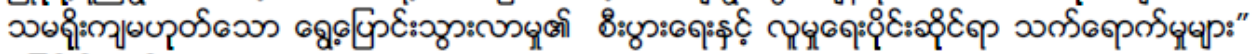
ïgøolosus!

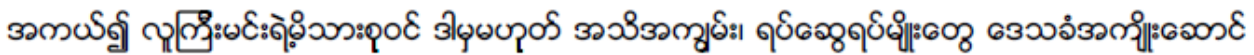

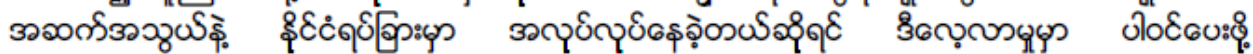

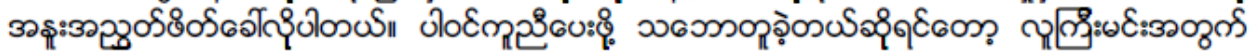

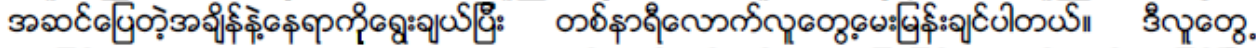

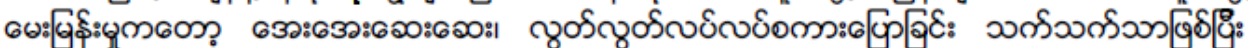

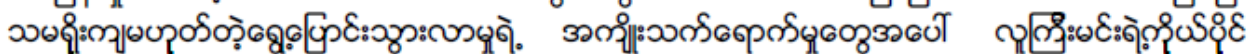

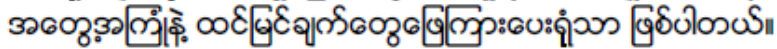

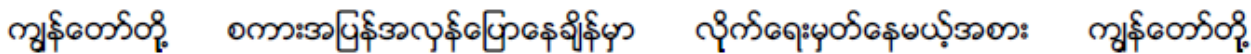

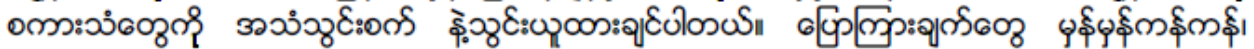

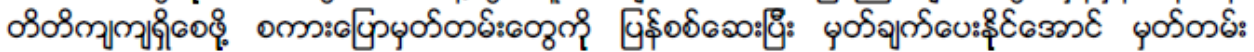

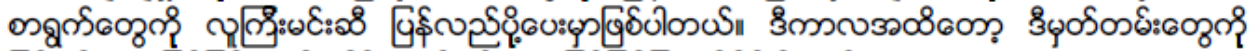

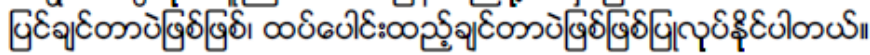

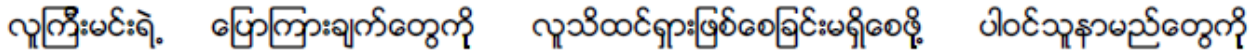

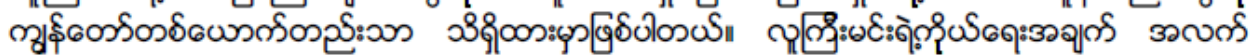

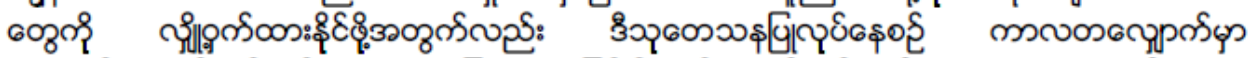

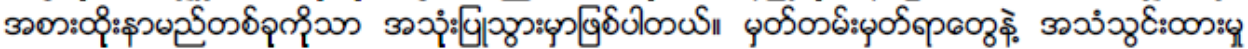

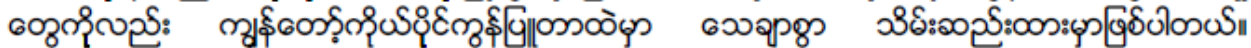

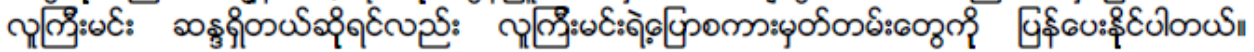

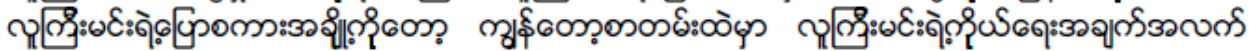

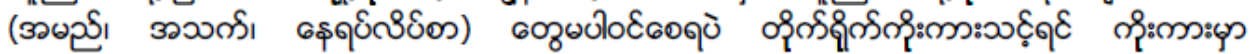

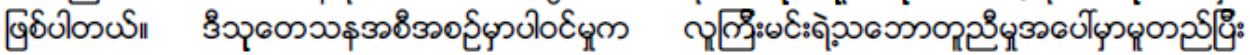




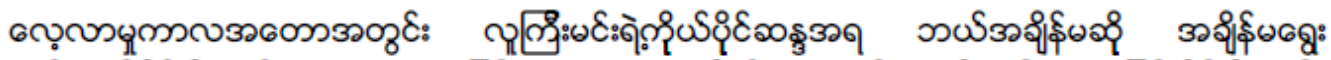

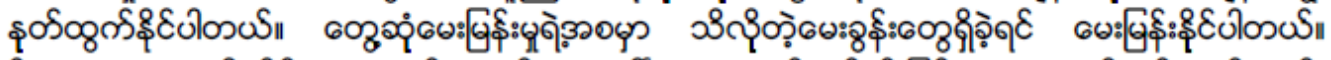

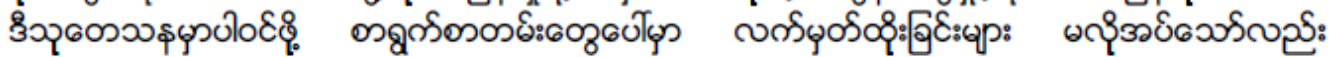

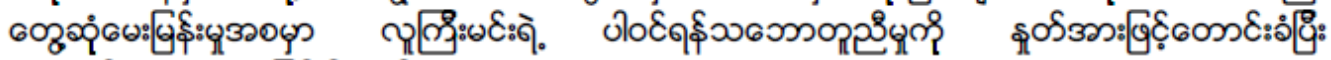

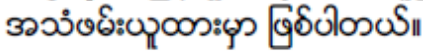

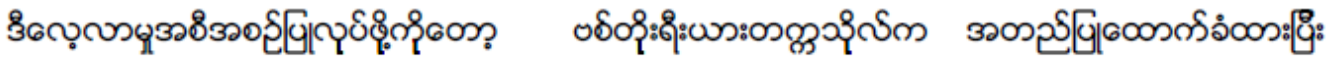

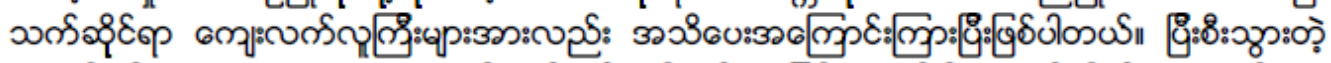

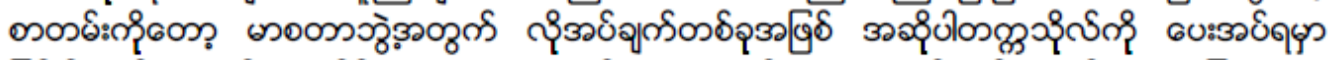

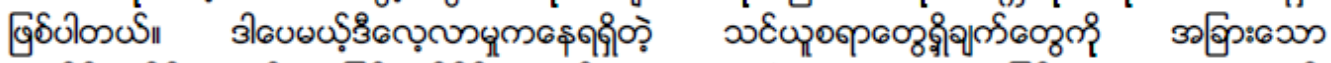

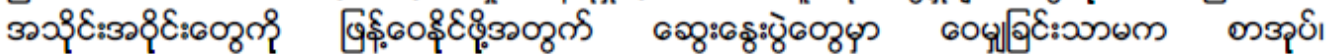

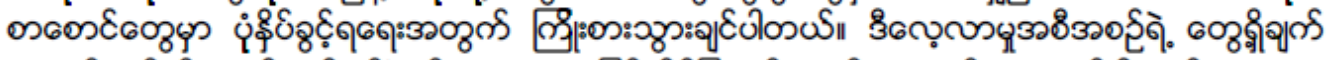

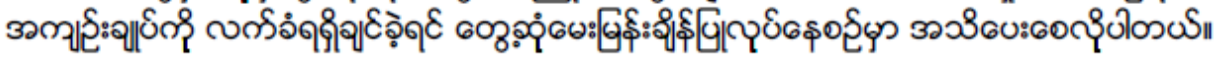

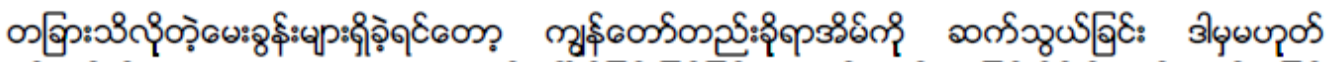

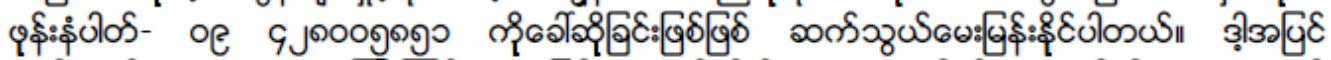

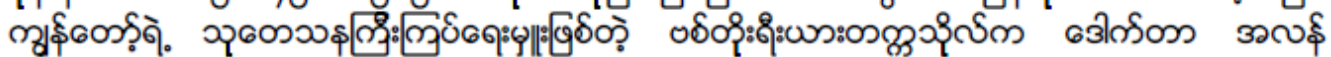

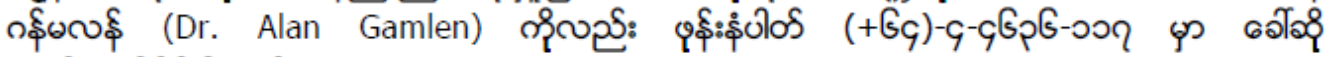

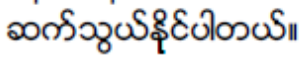

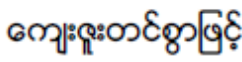

గియించ్రీ్గ 


\section{APPENDIX VI: Participant information sheet}

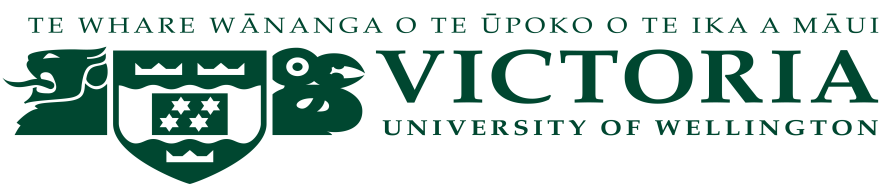

\section{Participant's Information Sheet [translated into Burmese]}

\section{Research Title: Social and Economic Effects of Irregular Migration on the families of migrants in Myanmar}

My name is Ko Ko Si Thu and I am a student at Victoria University of Wellington, New Zealand. I am currently studying for a Masters in Development Studies by thesis. My thesis project will explore the social and economic effects of irregular migration on the families of migrants in Myanmar.

If one or more members of your family have gone abroad using the services of a local broker, I would appreciate if you would consider taking part in this study. If you agree to participate, I would like to have a one-hour long interview with you at any time and place suitable for you. The interview will be informal and the discussion will be to explore your opinion about the effects of irregular migration reflecting your own experience.

I would like to record our conversation using an MP3 recorder, rather than taking notes as this will help us to discuss without any disturbance. To make sure your views have been accurately transcribed, I will return your transcripts to you so you can read and comment on them. At this stage, you can add to, or change the transcription.

Your confidentially will be assured as your name will be known to myself only. I will use a pseudonym during the research process to protect your identity. Storage of the recordings and transcriptions will be kept securely in a password-protected folder in my personal computer. If you prefer, your transcripts will be return to you. I may quote some of your words to illustrate points in the written report of the research. However, no identifying personal information such as name, address and age will be included in my report. You will be free to withdraw from the research at any time during the process and your involvement is based on your informed consent. You will be given the opportunity to ask questions at the start of the interview, and although you will not be asked to sign anything, your informed consent will be recorded orally once these questions have been addressed.

This study has been approved by the Victoria University of Wellington Ethics Committee. The research report has to be submitted to the university to fulfill the 
requirements of the Masters degree. However, I would like to share the findings in seminars with other community members and explore the possibility of publishing the results of the study in relevant academic journals. If you wish to receive a written summary of the findings of the study, please let me know during the interview.

If you have any questions about the study you may either contact me at Daw Nann Mi's home or by calling 09-428001549 or through Daw Nann Mi's Number 08321573. You may also contact Dr. Alan Gamlen, my research supervisor at Victoria University of Wellington on (+64)-4-4636-117.

Ko Ko Si Thu 


\section{APPENDIX VII: Information letter to village (Burmese)}

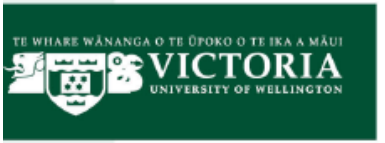

SCHOOL OF GEOGRAPHY, ENVIRONMENT AND EARTH SCIENCES

Te Kura Tătai Aro Whenua

VICTORIA UNIVERSITY OF WELLINGTON, PO Box 600 , Wellington 6140 , New Zealand

Phone +64 44635337 Fax +64-4-4635261 Email geo-enquiries@vuw.ac.nz Web Http://www.victoria.ac.nz/sgees

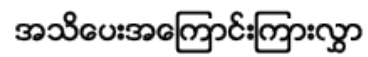

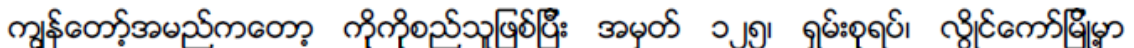

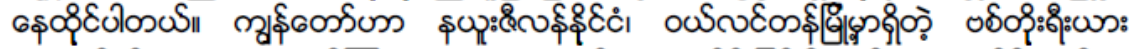

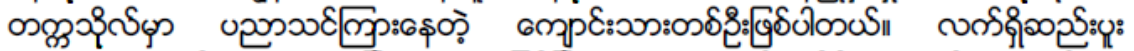
எ\$ంฺेమ

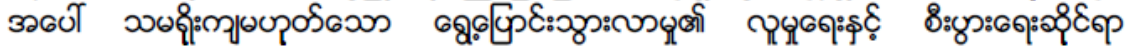

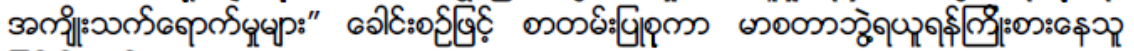
Géclosul|I

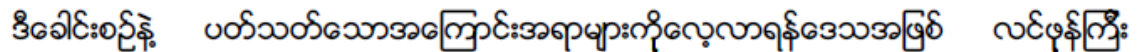

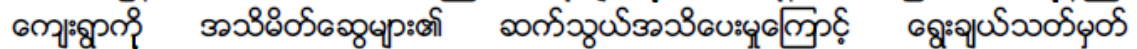

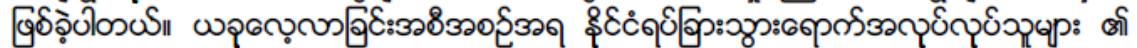

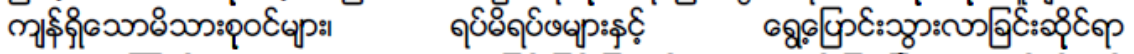

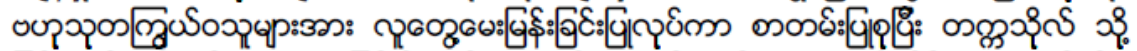

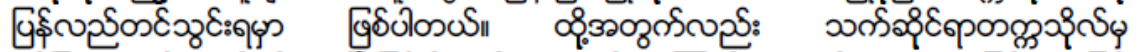

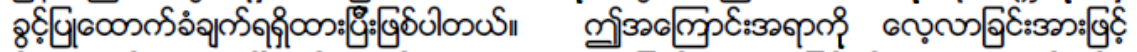

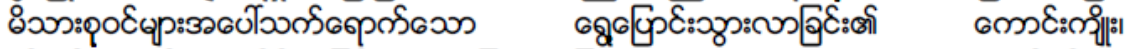

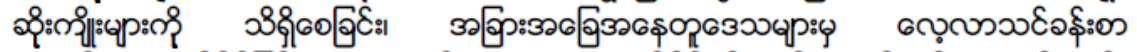

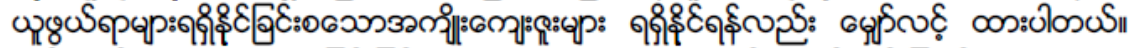

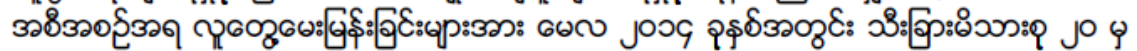

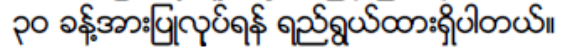

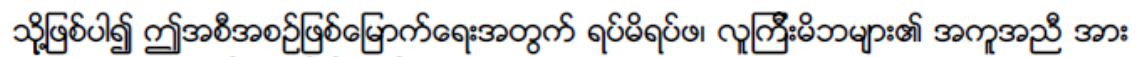

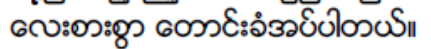

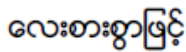

๑న్రీజ్గ 


\section{APPENDIX VIII: Location map of Kayah State}

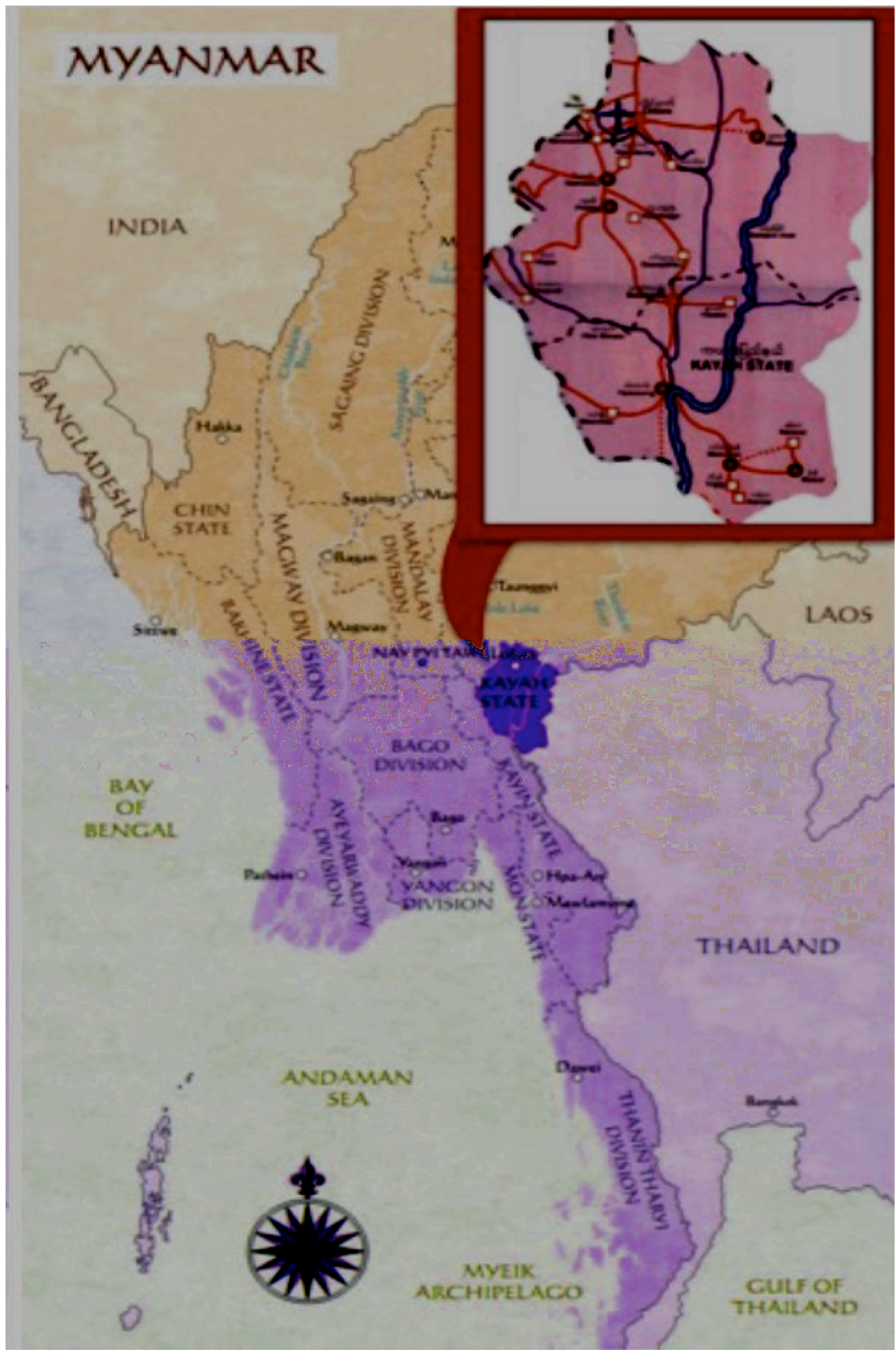




\section{APPENDIX IX: Nan Kham Village location}

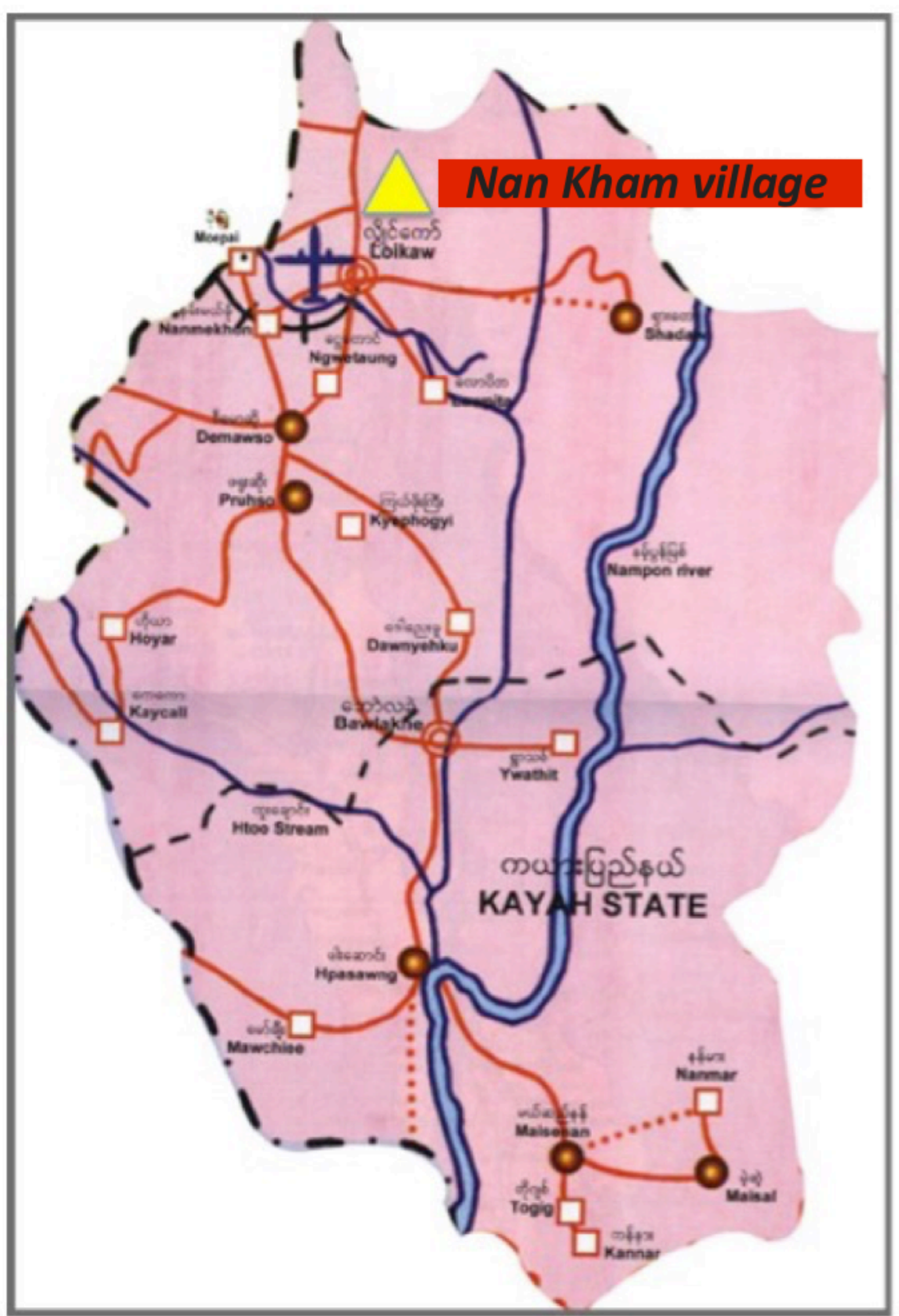



